\title{
Instrumentation and measurement strategy for the NOAA SENEX aircraft campaign as part of the Southeast Atmosphere Study 2013
}

Carsten Warneke ${ }^{1,2}$, Michael Trainer ${ }^{2}$, Joost A. de Gouw ${ }^{1,2}$, David D. Parrish ${ }^{1,2}$, David W. Fahey ${ }^{2}$, A. R. Ravishankara ${ }^{2, a}$, Ann M. Middlebrook ${ }^{2}$, Charles A. Brock ${ }^{2}$, James M. Roberts ${ }^{2}$, Steven S. Brown ${ }^{2}$, Jonathan A. Neuman ${ }^{1,2}$, Brian M. Lerner ${ }^{1,2}$, Daniel Lack ${ }^{1,2}$, Daniel Law ${ }^{1,2}$, Gerhard Hübler ${ }^{1,2}$, Iliana Pollack ${ }^{1,2, a}$, Steven Sjostedt $^{1,2}$, Thomas B. Ryerson ${ }^{2}$, Jessica B. Gilman ${ }^{1,2}$, Jin Liao ${ }^{1,2}$, John Holloway ${ }^{1,2}$, Jeff Peischl ${ }^{1,2}$, John B. Nowak ${ }^{1,2, b}$, Kenneth C. Aikin ${ }^{1,2}$, Kyung-Eun Min ${ }^{1,2, c}$, Rebecca A. Washenfelder ${ }^{1,2}$, Martin G. Graus ${ }^{1,2, d}$, Mathew Richardson $^{1,2}$, Milos Z. Markovic ${ }^{1,2, \mathrm{e}}$, Nick L. Wagner ${ }^{1,2}$, André Welti ${ }^{1,2, \mathrm{f}}$, Patrick R. Veres ${ }^{1,2}$, Peter Edwards ${ }^{1,2, g}$, Joshua P. Schwarz ${ }^{2}$, Timothy Gordon ${ }^{1,2}$, William P. Dube ${ }^{1,2}$, Stuart A. McKeen ${ }^{1,2}$, Jerome Brioude $^{1,2}$, Ravan Ahmadov ${ }^{1,2}$, Aikaterini Bougiatioti ${ }^{3}$, Jack J. Lin ${ }^{3}$, Athanasios Nenes ${ }^{3,11,12}$, Glenn M. Wolfe ${ }^{4,9}$, Thomas F. Hanisco ${ }^{4}$, Ben H. Lee ${ }^{5}$, Felipe D. Lopez-Hilfiker ${ }^{5}$, Joel A. Thornton ${ }^{5, i}$, Frank N. Keutsch $^{6, h}$, Jennifer Kaiser ${ }^{6, j}$, Jingqiu Mao ${ }^{7,10}$, and Courtney D. Hatch ${ }^{8}$

${ }^{1}$ Cooperative Institute for Research in Environmental Sciences, Univ. of Colorado, Boulder, CO, USA USA

${ }^{2}$ Chemical Sciences Division, NOAA Earth System Research Laboratory, Boulder, CO, USA

${ }^{3}$ Georgia Institute of Technology, Atlanta, GA, USA

${ }^{4}$ NASA Goddard Space Flight Center, Greenbelt, MD, USA

${ }^{5}$ University of Washington, Seattle, WA, USA

${ }^{6}$ University of Wisconsin-Madison, Madison, WI, USA

${ }^{7}$ Geophysical Fluid Dynamics Laboratory, NOAA, Princeton, NJ, USA

${ }^{8}$ Department of Chemistry, Hendrix College, 1600 Washington Ave., Conway, AR, USA

${ }^{9}$ University of Maryland Baltimore County, Baltimore, MD, USA

${ }^{10}$ Princeton University, Princeton, NJ, USA

${ }^{11}$ Foundation for Research and Technology Hellas, Hellas, Athens, Greece

${ }^{12}$ National Observatory of Athens, Athens, Greece

${ }^{a}$ now at: Department of Atmospheric Science, Colorado State University, Ft Collins, CO, USA

${ }^{b}$ now at: Aerodyne Research Inc., Billerica, MA, USA

${ }^{c}$ now at: Gwangju Institute of Science and Technology, Gwangju, Korea

${ }^{d}$ now at: Institute of Atmospheric and Cryospheric Sciences, University of Innsbruck, Innsbruck, Austria

${ }^{e}$ now at: Air Quality Processes Research Section, Environment Canada, Toronto, Ontario, Canada

${ }^{f}$ now at: Leibniz Institute for Tropospheric Research, Leipzig, Germany

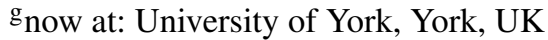

${ }^{\mathrm{h}}$ now at: Harvard University, Cambridge, MA, USA

${ }^{i}$ now at: Laboratory of Atmospheric Chemistry, Paul Scherrer Institute, Villigen, Switzerland

${ }^{j}$ now at: Harvard University, School of Engineering and Applied Sciences, Cambridge, MA, USA

Correspondence to: Carsten Warneke (carsten.warneke@noaa.gov)

Received: 9 December 2015 - Published in Atmos. Meas. Tech. Discuss.: 20 January 2016

Revised: 17 May 2016 - Accepted: 18 May 2016 - Published: 18 July 2016 
Abstract. Natural emissions of ozone-and-aerosol-precursor gases such as isoprene and monoterpenes are high in the southeastern US. In addition, anthropogenic emissions are significant in the southeastern US and summertime photochemistry is rapid. The NOAA-led SENEX (Southeast Nexus) aircraft campaign was one of the major components of the Southeast Atmosphere Study (SAS) and was focused on studying the interactions between biogenic and anthropogenic emissions to form secondary pollutants. During SENEX, the NOAA WP-3D aircraft conducted 20 research flights between 27 May and 10 July 2013 based out of Smyrna, TN.

Here we describe the experimental approach, the science goals and early results of the NOAA SENEX campaign. The aircraft, its capabilities and standard measurements are described. The instrument payload is summarized including detection limits, accuracy, precision and time resolutions for all gas-and-aerosol phase instruments. The inter-comparisons of compounds measured with multiple instruments on the NOAA WP-3D are presented and were all within the stated uncertainties, except two of the three $\mathrm{NO}_{2}$ measurements.

The SENEX flights included day- and nighttime flights in the southeastern US as well as flights over areas with intense shale gas extraction (Marcellus, Fayetteville and Haynesville shale). We present one example flight on 16 June 2013, which was a daytime flight over the Atlanta region, where several crosswind transects of plumes from the city and nearby point sources, such as power plants, paper mills and landfills, were flown. The area around Atlanta has large biogenic isoprene emissions, which provided an excellent case for studying the interactions between biogenic and anthropogenic emissions. In this example flight, chemistry in and outside the Atlanta plumes was observed for several hours after emission. The analysis of this flight showcases the strategies implemented to answer some of the main SENEX science questions.

\section{Introduction}

The SENEX campaign (Southeast Nexus-Studying the Interactions between Natural and Anthropogenic Emissions at the Nexus of Climate Change and Air Quality) was a large-scale National Oceanic and Atmospheric Administration (NOAA) led field study in the southeastern United States (US) in summer 2013. The SENEX measurement platform was the NOAA WP-3D aircraft operated out of Smyrna, Tennessee. SENEX was part of a large, comprehensive and coordinated research effort to understand the emission sources, chemistry and meteorology of the summertime atmosphere in the southeastern US: the Southeast Atmosphere Study (SAS) (http: //www.eol.ucar.edu/field_projects/sas), which included the other field campaigns: Southern Oxidant and Aerosol Study (SOAS), Tropospheric HONO (TropHONO), and the North
American Airborne Mercury Experiment (NAAMEX). Besides the NOAA WP-3D, measurements during SAS were made on the following platforms and locations: the $\mathrm{Na}$ tional Science Foundation (NSF) National Center for Atmospheric Research (NCAR) C-130 aircraft, the Purdue University Duchess aircraft, the State University of New YorkStony Brook Long-EZ aircraft, the Centreville and Alabama Aquatic Biodiversity Centre (AABC) flux ground site located in Alabama, the Look Rock, the Tennessee ground site, the Research Triangle Park (RTP) ground site in North Carolina and Caltech chamber studies (FIXIT).

The detailed science goals for SENEX can be found in the SENEX white paper (http://esrl.noaa.gov/csd/projects/ senex/) and are briefly listed here.

1. Understanding the emissions of aerosol, aerosol and ozone $\left(\mathrm{O}_{3}\right)$ precursors, and greenhouse gases in the southeastern U.S. Special focus was aimed at evaluating available emission inventories for organic aerosol, black carbon, $\mathrm{NO}_{x}\left(\mathrm{NO}+\mathrm{NO}_{2}\right)$, volatile organic compounds (VOCs), sulfur dioxide $\left(\mathrm{SO}_{2}\right)$, greenhouse gases, and aerosol precursors from point sources such as coal-fired power plants, urban areas as well as biogenic VOC emissions. Another focus was to understand the importance of emissions from biomass burning in the region.

2. Understanding the formation mechanisms of secondary species such as ozone, sulfate and organic aerosols in the southeastern US. The main focus here was to determine the influence of biogenic emissions, nighttime chemistry, aqueous-phase processes, and organic nitrates on the formation of the secondary species.

3. Determining the composition and distribution of aerosol in the southeastern US. by looking at the relative abundance of sulfate, organics and other chemical components over the whole study region and at accessible altitude levels.

4. Quantifying deposition and loss processes critical for determining atmospheric concentrations of aerosol, ozone and $\mathrm{NO}_{y}$ (sum of nitrogen oxides).

5. Determining the climate-relevant properties of aerosol in the southeastern US. by looking at the extinction, absorption and $\mathrm{CCN}$ properties of aerosol from primary and secondary sources and their dependence on the high humidity in the southeastern US. Special focus was given on determining the fraction of organic aerosol that occurs naturally vs. the fraction that is controlled by anthropogenic emissions and how each may change in the future as a result of warming and changes in anthropogenic emissions. Additional focus was on black carbon and its co-emitted species to understand whether controlling specific BC sources has a net warming or cooling effect. 


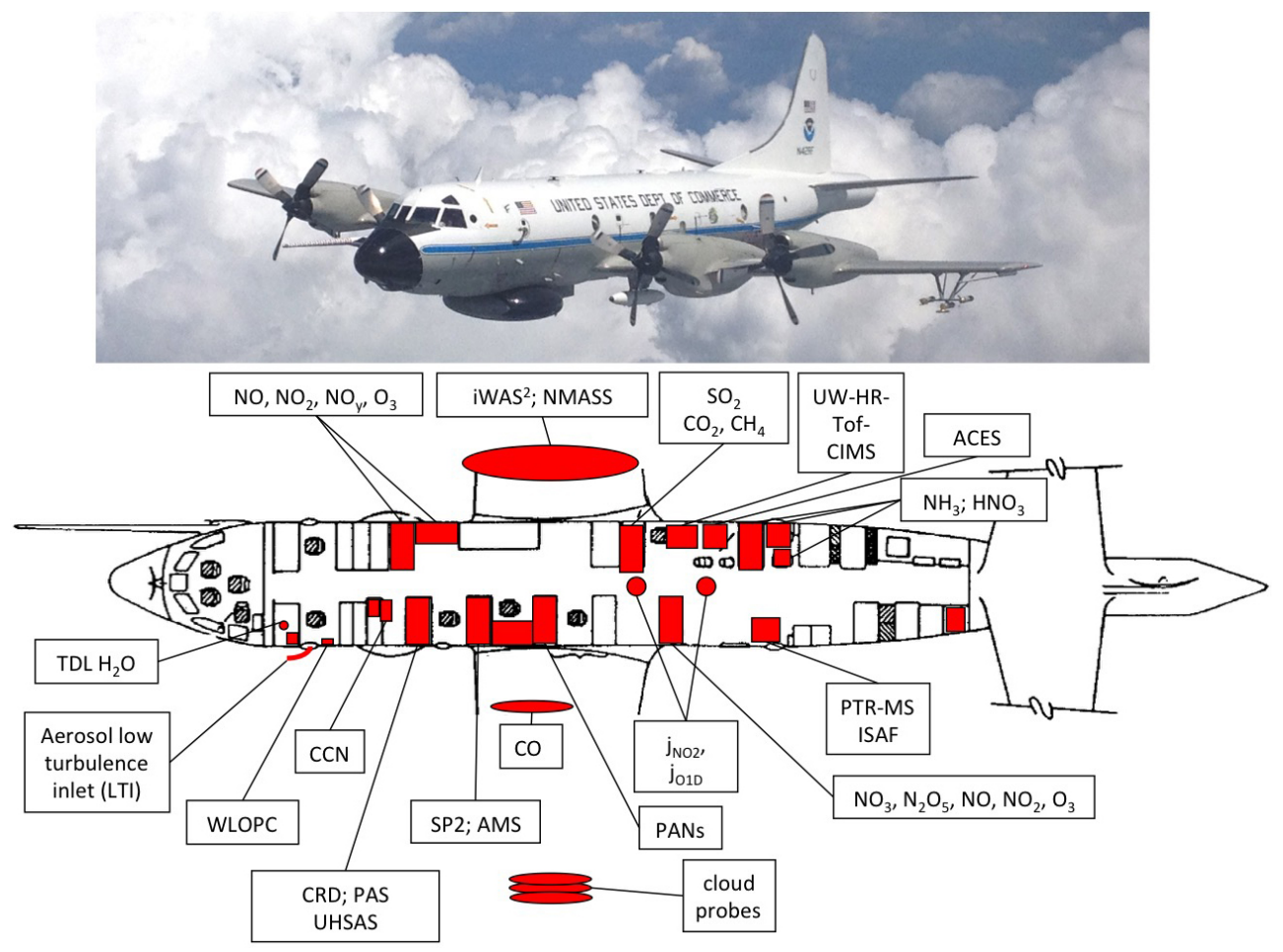

Figure 1. NOAA WP-3D aircraft picture, payload and layout. The photo was taken during the inter-comparison flight with the NCAR C-130 by Lynne Gratz.

6. Quantifying methane $\left(\mathrm{CH}_{4}\right)$ and VOC emissions from selected shale gas extraction regions (Marcellus, Haynesville and Fayetteville).

In this paper we describe the payload of the NOAA WP$3 \mathrm{D}$, describe the locations of the SENEX flights, show intercomparisons used to evaluate the measurements and describe an example flight to showcase the measurement strategies that were used during SENEX.

\section{Aircraft measurement description}

\subsection{NOAA WP-3D aircraft}

The two NOAA WP-3D aircraft have been used in air quality and climate related airborne field campaigns since 1994 . The NOAA WP-3D carried its maximum payload of $3600 \mathrm{~kg}$ of scientific equipment during SENEX in addition to foursix scientists. The aircraft has a range of $3000 \mathrm{~km}$ and a ceiling of about $7600 \mathrm{~m}$. During SENEX the highest altitude was about $6400 \mathrm{~m}$ due to the heavy payload. Flight duration was typically around $7 \mathrm{~h}$, and the majority of the flights were conducted in the daytime boundary layer approx. $0.5 \mathrm{~km}$ above ground level. In the boundary layer the aircraft travels at about $115 \mathrm{~m} \mathrm{~s}^{-1}$, which means that for most instruments measuring at $1 \mathrm{~Hz}$ one data point is an average of $115 \mathrm{~m}$. A picture of the aircraft taken during SENEX is shown in Fig. 1.
The WP-3D was equipped by the NOAA Aircraft Operations Center (AOC) flight facility with instruments detailing the position and motion of the aircraft as well as many meteorological parameters such as 3-D wind speed and direction, ambient, potential and dew point temperatures, water vapor mixing ratios, pressure and sea surface temperature. A list of the most commonly used aircraft-provided parameters and their uncertainties is given in Table 1.

\subsection{NOAA WP-3D SENEX flight summaries}

During SENEX a total of 20 research flights were conducted; of those, 2 were test flights from Tampa, FL and 2 were the transfer flights between Tampa, FL and Smyrna, TN. All of the flights, including the test and transfer flights, addressed multiple science goals. All the SENEX flight tracks are shown in Fig. 2 on a map of the southeastern US that also shows most of the larger point sources in the region. A total of 12 daytime, 3 nighttime and 5 shale gas region flights (Marcellus, Haynesville, and Fayetteville shale) were conducted to answer the major SENEX science questions. The flight tracks in Fig. 2 are color-coded by those three categories and details about each flight can be found in Tables 2,3 , and 4 , where a short description of the flight, the investigated emission sources, and the coordinating activities are listed. 
Table 1. Standard NOAA WP-3D provided parameters.

\begin{tabular}{|c|c|c|c|}
\hline Aircraft parameters & Technique & Units & Uncertainty \\
\hline \multirow[t]{5}{*}{ Aircraft position } & GPS latitude & $\circ$ & $\pm 16 \mathrm{~m}$ \\
\hline & GPS longitude & $\circ$ & $\pm 16 \mathrm{~m}$ \\
\hline & GPS altitude & $\mathrm{m}$ & $\pm 16 \mathrm{~m}$ \\
\hline & pressure altitude & $\mathrm{m}$ & $\pm 10 \mathrm{~m}$ \\
\hline & radar altitude above ground & $\mathrm{m}$ & $\pm 15 \mathrm{~m}$ or $1-2 \%$ \\
\hline \multirow[t]{10}{*}{ Aircraft meteorology } & ambient temperature & ${ }^{\circ} \mathrm{C}$ & $\pm 0.5^{\circ} \mathrm{C}$ \\
\hline & dew point temperature & ${ }^{\circ} \mathrm{C}$ & $\pm 0.5^{\circ} \mathrm{C}$ \\
\hline & TDL dew point temperature & ${ }^{\circ} \mathrm{C}$ & $5 \%$ \\
\hline & $\mathrm{H}_{2} \mathrm{O}$ mixing ratio* & $\mathrm{g} \mathrm{kg}^{-1}$ & $5 \%$ \\
\hline & potential temperature & ${ }^{\circ} \mathrm{K}$ & $\pm 0.5 \mathrm{~K}$ \\
\hline & relative humidity* & $\%$ & $\pm 5 \%$ \\
\hline & static pressure & & $\pm 2.2 \mathrm{mb}$ \\
\hline & vertical wind speed & $\mathrm{ms}^{-1}$ & $\pm 0.5 \mathrm{~m} \mathrm{~s}^{-1}$ \\
\hline & wind direction & & $5^{\circ}$ \\
\hline & wind speed & $\mathrm{ms}^{-1}$ & $1 \mathrm{~m} \mathrm{~s}^{-1}$ \\
\hline \multirow{8}{*}{$\begin{array}{l}\text { Aircraft } \\
\text { neous }\end{array}$} & attack angle & $\circ$ & $\pm 0.2^{\circ}$ \\
\hline & cabin pressure & $\mathrm{mb}$ & N/A \\
\hline & ground speed & $\mathrm{ms}^{-1}$ & $\pm 3.4 \mathrm{~m} \mathrm{~s}^{-1}$ \\
\hline & heading & $\circ$ & $\pm 0.5^{\circ}$ \\
\hline & pitch angle & $\circ$ & $\pm 0.05^{\circ}$ \\
\hline & roll angle & $\circ$ & $\pm 0.05^{\circ}$ \\
\hline & slip angle & & $\pm 0.2^{\circ}$ \\
\hline & true air speed & $\mathrm{ms}^{-1}$ & $\pm 0.5 \mathrm{~m} \mathrm{~s}^{-1}$ \\
\hline
\end{tabular}

${ }^{*} \mathrm{H}_{2} \mathrm{O}$ mixing ratio and relative humidity are derived from dew point temperature

\subsection{NOAA WP-3D SENEX chemical and aerosol instrumentation}

The WP-3D instrumentation payload on the WP-3D was specifically designed to provide the necessary measurements to answer the SENEX science questions. The instrumentation included a wide variety of gas and aerosol-phase measurements. A schematic drawing of the payload of the WP3D is shown in Fig. 1b. All the instruments for aerosol phase measurements are listed in Table 5 and for gas phase measurements in Table 6 together with their measurement technique, accuracy, and precision, sample interval, and a reference to a publication describing the respective instrument in detail. Overall 22 different instruments were installed on the NOAA WP-3D with a total power consumption of $40 \mathrm{~A}$ $(110 \mathrm{~V}, 400 \mathrm{~Hz} 3$ phase $), 130 \mathrm{~A}(110 \mathrm{~V}, 400 \mathrm{~Hz}), 40 \mathrm{~A}(110 \mathrm{~V}$

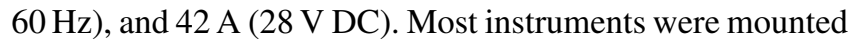
inside the fuselage, but two instrumented wingpods added significant scientific payload capacity including 72 wholeair canister samples, a carbon monoxide (CO) analyzer and the fine particle counter to add significant scientific payload capacity. Four to six scientists were on board during each flight to monitor all the instruments and adjust the flight plans to current meteorological conditions as needed. During the flights, selected aircraft and instrument data were streamed to the ground and could be monitored in near real time on a website for situational awareness for all SONGNEX scientists.

A detailed description for each instrument can be found in Appendix A; in the following two paragraphs the instrument name and measurement technique are given and in Tables 5 and 6 , accuracy, precision, sample interval and literature reference are listed in addition.

Aerosol-phase measured parameters were: (1) the particle $(0.004-8.3 \mu \mathrm{m})$ number, size and volume with parallel condensation particle counters (CPCs) and white and laser light scattering, (2) sub-micrometer extinction and absorption of dry, humidified, and thermodenuded aerosol at three wavelengths spanning the visible with a cavity ring-down aerosol extinction spectrometer (CRD) and a photoacoustic aerosol absorption spectrometer (PAS), (3) the non-refractory submicron aerosol composition of organics, sulfate, nitrate, ammonium and chloride with an aerosol mass spectrometer (AMS), (4) cloud condensation nuclei (CCN) spectra between 0.1-0.8\% supersaturation, (5) accumulation-mode refractory black carbon (rBC) mass content of single particles with an SP2. The aerosol instrumentation inside the fuselage was connected to a low turbulence inlet (LTI) (Wilson et al., 2004), which slows down the sample flow from aircraft speeds to $5 \mathrm{~m} \mathrm{~s}^{-1}$ generating minimal turbulence and improving particle transmission. The NMASS, measuring ultrafine particles, is subject to diffusive rather than inertial 


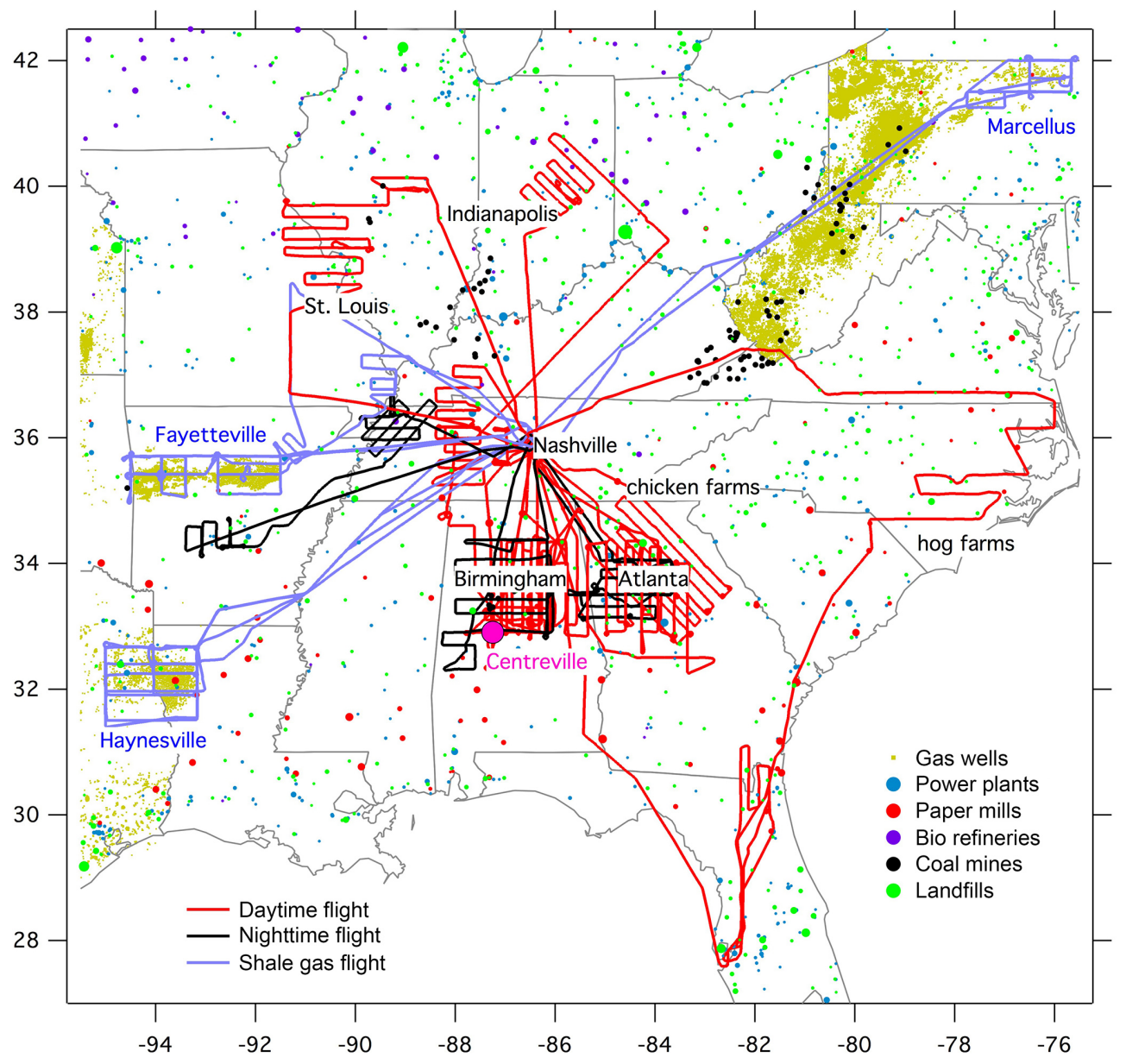

Figure 2. NOAA WP-3D flight tracks for daytime, nighttime and shale gas flights during SENEX. The marker size for the power plants is the annual gross load, for the paper mills the capacity, for the bio refineries the biofuel production, for the coal mines the methane emissions, and for the land fills the methane emissions.

losses and sampled instead from a double diffusing inlet in the non-pressurized wing pod.

Gas-phase measurements were the following: (1) the greenhouse gases carbon dioxide $\left(\mathrm{CO}_{2}\right)$ and methane $\left(\mathrm{CH}_{4}\right)$ with wavelength scanned cavity ring-down spectroscopy, (2) two measurements of nitric oxide $(\mathrm{NO})$ and $\mathrm{O}_{3}$, each measured by gas-phase chemiluminescence (CL) and by cavity ring-down absorption spectroscopy (CRDS), three measurements of nitrogen dioxide $\left(\mathrm{NO}_{2}\right)$, by UV photolysis and gas-phase chemiluminescence (P-CL) and by CRDS and by airborne cavity enhanced absorption spectroscopy (ACES), $\mathrm{NO}_{y}$ by gold-catalyzed thermal conversion and gas-phase CL, (3) carbon monoxide (CO) with vacuum UV resonance fluorescence, (4) $\mathrm{SO}_{2}$ with pulsed UV fluorescence, (5) ammonia $\left(\mathrm{NH}_{3}\right)$, nitric acid $\left(\mathrm{HNO}_{3}\right)$, and two measurements of nitrous acid (HONO), and formic acid $(\mathrm{HCOOH})$ with chemical ionization mass spectrometry (CIMS), and (6) the nighttime oxidants $\mathrm{NO}_{3}$ and $\mathrm{N}_{2} \mathrm{O}_{5}$ with CRDS and CIMS. Various volatile organic compounds (VOCs) were measured with several different techniques: (7) oxygenates, aromatics, iso- prene, monoterpenes and acetonitrile with proton-transferreaction mass spectrometry (PTR-MS); (8) hydrocarbons, halocarbons and a few selected oxygenates from canister samples and post-flight GC-MS analysis (iWAS/GCMS); (9) formaldehyde with the In Situ Airborne Formaldehyde (ISAF) using laser-induced fluorescence (LIF); (10) glyoxal with ACES; (11) organic and inorganic acids by UW-TOFCIMS; and (12) peroxyacyl nitrates PANs and nitryl chloride $\left(\mathrm{ClNO}_{2}\right)$ with a separate CIMS. In addition up and down welling photolysis rates $\left(j_{\mathrm{NO}_{2}}\right.$ and $\left.j_{\mathrm{O}_{3}}\right)$ were measure with filter radiometers.

All gas phase instruments used dedicated inlets, which were either $3 / 8^{\prime \prime}$ O.D. rearward-facing tubes or airfoil winglets mounted in place of aircraft windows extending beyond the aircraft boundary layer. The total inlet lengths varied from about $0.3-2 \mathrm{~m}$ for the different instruments. For example, the $\mathrm{HNO}_{3}$ and $\mathrm{NH}_{3}$-CIMS instruments had their reaction chambers mounted a few centimeters away from the window plate and the inlet length was largely determined by the $50 \mathrm{~cm}$ length of the winglet needed to sample outside the 
Table 2. Flight descriptions for the NOAA WP-3D daytime flights in the SE US.

\begin{tabular}{|c|c|c|c|}
\hline Flight date in 2013 & Day of the week & Description & $\begin{array}{l}\text { Investigated emission } \\
\text { source }\end{array}$ \\
\hline 29 May & Wednesday & $\begin{array}{l}\text { Test flight in Florida } \\
\text { Jacksonville } \\
\text { St John's River }\end{array}$ & $\begin{array}{l}\text { biogenic } \\
\text { urban } \\
\text { power plant }\end{array}$ \\
\hline 31 May & Friday & $\begin{array}{l}\text { Test flight in Florida } \\
\text { Jacksonville } \\
\text { St John's River }\end{array}$ & $\begin{array}{l}\text { biogenic } \\
\text { urban } \\
\text { power plant }\end{array}$ \\
\hline 3 June & Monday & $\begin{array}{l}\text { Transfer Tampa to Smyrna } \\
\text { Birmingham } \\
\text { EC Gaston, Johnsonville, Cumberland, } \\
\text { Colbert } \\
\text { Centreville spiral }\end{array}$ & $\begin{array}{l}\text { urban } \\
\text { power plant } \\
\text { coal mine }\end{array}$ \\
\hline 11 June & Tuesday & $\begin{array}{l}\text { Centreville } \\
\text { Birmingham west to east } \\
\text { EC Gaston }\end{array}$ & $\begin{array}{l}\text { urban } \\
\text { urban } \\
\text { power plant }\end{array}$ \\
\hline 12 June & Wednesday & $\begin{array}{l}\text { Atlanta west to east } \\
\text { Scherer, Bowen, Yates, Wansley, Harlee } \\
\text { Branch }\end{array}$ & $\begin{array}{l}\text { urban } \\
\text { power plant }\end{array}$ \\
\hline 16 June & Sunday & $\begin{array}{l}\text { Atlanta southwest to northeast on weekend } \\
\text { Scherer, Bowen, Yates, Wansley, Harlee } \\
\text { Branch } \\
\text { paper mills, landfills } \\
\text { poultry farming }\end{array}$ & $\begin{array}{l}\text { power plant } \\
\text { point sources } \\
\text { point sources } \\
\text { agriculture }\end{array}$ \\
\hline 18 June & Tuesday & Aborted flight, circled over Franklin & \\
\hline 22 June & Saturday & $\begin{array}{l}\text { Birmingham and Atlanta west to east } \\
\text { Centreville } \\
\text { EC Gaston } \\
\text { coal mines, land fills, paper mills }\end{array}$ & $\begin{array}{l}\text { urban } \\
\text { urban } \\
\text { power plant } \\
\text { point sources }\end{array}$ \\
\hline 23 June & Sunday & $\begin{array}{l}\text { Indianapolis } \\
\text { biogenic/landscape emission change } \\
\text { Johnsonville, Cumberland }\end{array}$ & $\begin{array}{l}\text { urban } \\
\text { biogenic } \\
\text { power plant }\end{array}$ \\
\hline 29 June & Saturday & $\begin{array}{l}\text { Centreville } \\
\text { C-130 inter-comparison } \\
\text { Birmingham } \\
\text { James H Miller Jr, EC Gaston }\end{array}$ & $\begin{array}{l}\text { urban } \\
\text { power plant } \\
\text { urban }\end{array}$ \\
\hline 5 July & Friday & $\begin{array}{l}\text { Ozarks } \\
\text { St Louis } \\
\text { Archer Daniels Midland biofuel refinery }\end{array}$ & $\begin{array}{l}\text { biogenic } \\
\text { urban } \\
\text { point source }\end{array}$ \\
\hline 10 July & Wednesday & $\begin{array}{l}\text { Transfer flight Smyrna to Tampa } \\
\text { coal mines, paper mill } \\
\text { hog farming }\end{array}$ & $\begin{array}{l}\text { point sources } \\
\text { point sources } \\
\text { agriculture }\end{array}$ \\
\hline
\end{tabular}

aircraft boundary layer. Detailed descriptions of the inlets for the individual instruments can be found in the instrument descriptions in the Appendix.

\section{Inter-comparison of duplicate measurements on the WP-3D}

Some parameters were measured by more than one instrument on the WP-3D, giving opportunities for intercomparisons and the results are described in the following. 
Table 3. Flight descriptions for the NOAA WP-3D nighttime flights in the SE US.

\begin{tabular}{llll}
\hline Flight Date in 2013 & Day of the week & Description & $\begin{array}{l}\text { Investigated emission } \\
\text { sources }\end{array}$ \\
\hline 19 June & Wednesday & $\begin{array}{l}\text { Atlanta day into night } \\
\text { Missed approaches } \\
\text { step profile in aged Atlanta plume }\end{array}$ & urban \\
& & Birmingham north to south \\
& Centreville & \\
\hline Juesday July & & JH Miller, EC Gaston, Gorgas, US Steel, & power plants \\
& & Neene County & urban \\
& & agricultural fire & power plants \\
& Wednesday & & biomass burning \\
\hline 3 July & & &
\end{tabular}

Table 4. Flight descriptions for the NOAA WP-3D flights in shale gas regions.

\begin{tabular}{llll}
\hline Flight Date in 2013 & Day of the week & Shale Play & $\begin{array}{l}\text { Additional investigated } \\
\text { emission sources }\end{array}$ \\
\hline $\begin{array}{l}\text { 10 June } \\
\text { 25 June }\end{array}$ & $\begin{array}{l}\text { Monday } \\
\text { Tuesday } \\
\text { 26 June }\end{array}$ & $\begin{array}{l}\text { Haynesville } \\
\text { Haynesville }\end{array}$ & \\
6 July & Fayetteville & Biogenics in Ozarks \\
8 July & Saturday & Marcellus & Independence power plant \\
& Monday & Fayetteville & New Madrid power plant \\
\hline
\end{tabular}
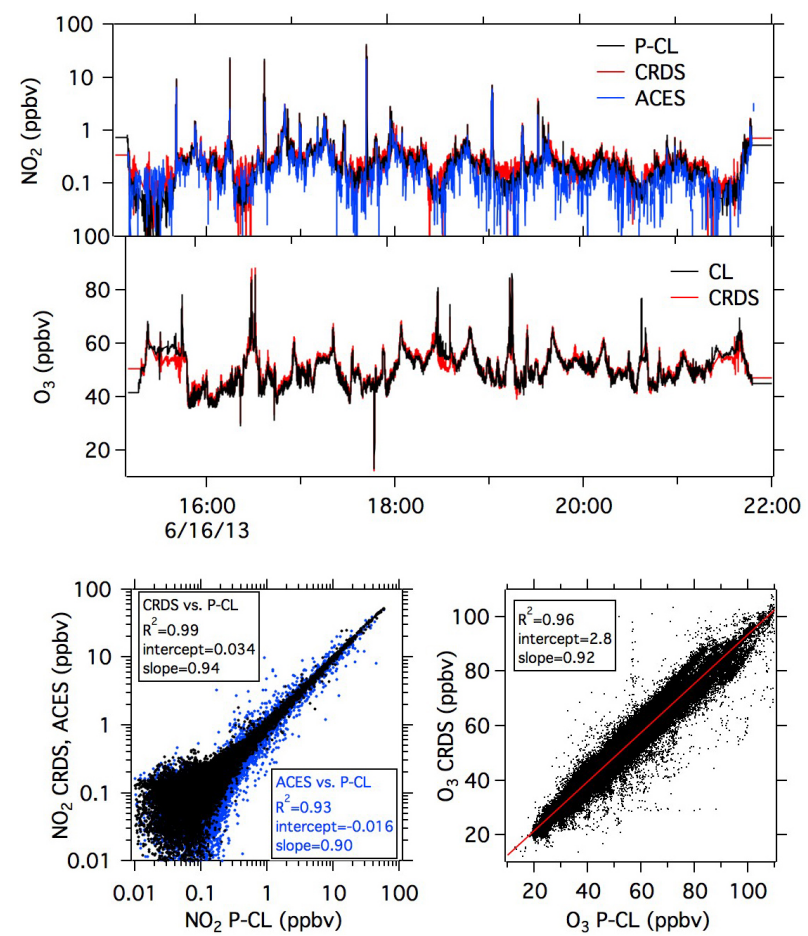

Figure 3. $\mathrm{NO}_{2}$ inter-comparison between P-CL, CRDS and ACES instruments and ozone inter-comparison between P-CL and CRDS.

Three instruments measured $\mathrm{NO}_{2}$ : P-CL, CRDS, and ACES. The agreement between CRDS and ACES with the standard P-CL technique, as shown in Fig. 3, was on average 6 and $10 \%$ and the measurements were correlated with a linear correlation coefficient $\left(R^{2}\right)$ of 0.99 and 0.93 , respectively. The agreement is within the combined uncertainties, given in Table 6, for CRDS and just outside for ACES and P-CL. Two instruments measured ozone: P-CL and CRDS and the intercomparison is also shown in Fig. 3. The ozone measurements correlated with $R^{2}$ of 0.96 and agreed on average within $8 \%$, which is within the combined measurement uncertainties of the two instruments as given in Table 6. All the data for the whole campaign were included for this inter-comparison using 1-second ozone data; $\mathrm{NO}_{2}$ data were averaged to the $5 \mathrm{~s}$ ACES time resolution. Two instruments measured NO: CL and CRDS, with the CRDS data subject to an optical instability that degraded the detection limit during this campaign. The large majority of the data were below this degraded detection limit, and therefore the inter-comparison was not included here.

Benzene, toluene, isoprene, methanol, acetone, methyl vinyl ketone plus methacrolein (MVK + MACR) and methyl ethyl ketone (MEK) were measured on the WP-3D with both the PTR-MS and with iWAS/GCMS. As an example the isoprene time series for the flight on 29 June 2013 is shown for both instruments in Fig. 4. For the purpose of this comparison, the PTR-MS data are averaged over an interval that 
Table 5. Aerosol instrumentation on the NOAA WP-3D during SENEX.

\begin{tabular}{|c|c|c|c|c|c|}
\hline Measurement & Name/technique & Accuracy & Precision & $\begin{array}{l}\text { Sample } \\
\text { Interval }\end{array}$ & Reference \\
\hline Low turbulence inlet & $\begin{array}{l}\text { LTI: decelerating inlet to pro- } \\
\text { vide sample air to aerosol in- } \\
\text { struments in fuselage }\end{array}$ & N/A & N/A & N/A & Wilson et al. (2004) \\
\hline $\begin{array}{l}\text { Size distributions fine } \\
(0.004-1 \mu \mathrm{m}) \text { and coarse } \\
(1-8.3 \mu \mathrm{m})\end{array}$ & $\begin{array}{l}\text { parallel CPCs, and white and } \\
\text { laser light scattering }\end{array}$ & & & $1 \mathrm{~s}$ & Brock et al. $(2000,2011)$ \\
\hline $\begin{array}{l}\text { Cloud condensation nuclei } \\
(\mathrm{CCN}) \text { spectra from } 0.1- \\
0.8 \% \text { supersaturation }\end{array}$ & $\begin{array}{l}\text { CCN: Continuous-flow stream- } \\
\text { wise thermal-gradient CCN } \\
\text { counter with scanning flow } \\
\text { CCN analysis (SCFA) }\end{array}$ & $\begin{array}{l}\text { Number: } 10 \% \\
\text { super-saturation: } \\
0.04 \%\end{array}$ & $10 \mathrm{CCN} \mathrm{cm}^{-3}$ & $60 s$ & $\begin{array}{l}\text { Lance et al. (2006), Lin } \\
\text { et al. (2016), Moore and } \\
\text { Nenes (2009), Roberts and } \\
\text { Nenes (2005) }\end{array}$ \\
\hline $\begin{array}{l}\text { Eight-cell optical extinc- } \\
\text { tion (dry } 405,532,662 \mathrm{~nm} \text {, } \\
70 \text { and } 90 \% \text { RH } 532 \mathrm{~nm} \text {, } \\
\text { thermodenuded } 405 \text { and } \\
662 \mathrm{~nm} \text { ) }\end{array}$ & $\begin{array}{l}\text { CRD: Cavity ring-down aerosol } \\
\text { extinction spectrometer }\end{array}$ & $<2 \%$ & $\begin{array}{l}10 \% \\
0.1 \mathrm{Mm}^{-1}\end{array}$ & $1 \mathrm{~s}$ & Langridge et al. (2011) \\
\hline $\begin{array}{l}\text { Five-cell optical absorption } \\
\text { (dry 405, 532, } 662 \mathrm{~nm} \text {, } \\
\text { thermodenuded } 405 \text { and } \\
662 \mathrm{~nm})\end{array}$ & $\begin{array}{l}\text { PAS: Photoacoustic Absorption } \\
\text { Spectrometer }\end{array}$ & $10 \%$ & $1 \mathrm{Mm}^{-1}$ & $1 \mathrm{~s}$ & Lack et al. (2012) \\
\hline $\begin{array}{l}\text { Refractory BC mass con- } \\
\text { tent of individual particles }\end{array}$ & $\begin{array}{l}\text { SP2: Single-Particle Soot Pho- } \\
\text { tometer with laser-induced in- } \\
\text { candescence }\end{array}$ & $30 \%$ & $\begin{array}{l}0.5 \mathrm{fg}(0.08 \mu \mathrm{m} \\
\text { mass-equiv. } \\
\text { diameter with } \\
2 \mathrm{~g} \mathrm{cc}^{-1} \text { den- } \\
\text { sity })\end{array}$ & $1 \mathrm{~s}$ & Schwarz et al. $(2008,2010)$ \\
\hline $\begin{array}{l}\text { Non-refractory, submicron } \\
\text { sulfate, nitrate, ammonium, } \\
\text { organic, and chloride mass } \\
\text { concentrations }\end{array}$ & $\begin{array}{l}\text { AMS: Aerosol Mass } \\
\text { Spectrometer }\end{array}$ & $50 \%$ & $\begin{array}{l}0.05,0.07, \\
0.24,0.36, \text { and } \\
0.05 \mu \mathrm{g} \mathrm{sm}^{-3} \\
\text { (study average) }\end{array}$ & $10 \mathrm{~s}$ & Bahreini et al. (2009) \\
\hline $\begin{array}{l}\text { Cloud particle size distribu- } \\
\text { tion }(0.6-50 \mu \mathrm{m}) \\
(3-50 \mu \mathrm{m}) \\
(50-6000 \mu \mathrm{m})\end{array}$ & $\begin{array}{l}\text { Cloud probes: Laser light for- } \\
\text { ward and back scattering } \\
\text { laser light forward scattering } \\
\text { droplet imaging probe }\end{array}$ & & & $1 \mathrm{~s}$ & Lance et al. (2010) \\
\hline
\end{tabular}

starts $10 \mathrm{~s}$ before and stops $10 \mathrm{~s}$ after the canister filling time, which was about 3-10 s, while the PTR-MS measures for $1 \mathrm{~s}$ every $17 \mathrm{~s}$. This averaging ensured that at least one PTR-MS data point was used for each canister sample, but adds additional scatter to the inter-comparison. Isoprene has a very high variability in the boundary layer, due to its short lifetime and high emissions. This variability and imperfect time alignment causes a large part of the scatter observed in Fig. 4. The scatter plots for the inter-comparison of isoprene and other VOCs are shown in Fig. 4 as well. The comparison had slopes between $0.64-1.45$, which is just within the combined uncertainties of the two instruments given in Table 6 , and $R^{2}$ of 0.5 or higher. The iWAS/GCMS was deployed during SENEX for the first time and some instrument issues occurred, causing some degradation of the data quality compared to previous inter-comparisons (de Gouw and Warneke, 2007; Warneke et al., 2011a). More details on the instrument performance during SENEX, the inter-comparison and the stability of VOCs, especially oxygenates, in canisters can be found in Lerner at al. (2016).

Two instruments measured formic acid $(\mathrm{HCOOH})$ : the $\mathrm{HNO}_{3}$-CIMS and the University of Washington highresolution time-of-flight chemical ionization mass spectrometer (UW HR-ToF-CIMS) and their comparison is shown in Fig. 5. The time series shows results from one individual flight and the scatter plot shows all data from the campaign, where the color code indicates the individual flights. The comparison using all the data has a slope of 1.03 and $R^{2}$ of 0.80 , while the slopes of individual flights ranged from 1.40 to 0.66 with $R^{2}$ always higher than 0.91 . The reason for the flight-to-flight variability in their agreement is yet unknown. The output of the continuously added ${ }^{13} \mathrm{C}$ formic acid permeation device - to which the UW HR-ToF-CIMS instrument sensitivity was referenced (see SI) - may have contributed to the variability of the reported formic acid mixing ratio between flights, because an independent method of 
Table 6. Gas-phase instrumentation on the NOAA WP-3D during SENEX.

\begin{tabular}{|c|c|c|c|c|c|}
\hline Measurement & Technique & Accuracy & $\begin{array}{l}\text { Precision or } \\
\text { Detec. Limit }\end{array}$ & Sample Interval & Reference \\
\hline $\begin{array}{l}\mathrm{CH}_{4} \\
\mathrm{CO}_{2}\end{array}$ & $\begin{array}{l}\text { wavelength-scanned cavity } \\
\text { ring-down absorption spec- } \\
\text { troscopy }\end{array}$ & $\begin{array}{l}0.07 \mathrm{ppm} \\
1 \mathrm{ppb}\end{array}$ & $\begin{array}{l}0.11 \mathrm{ppm} \\
0.4 \mathrm{ppb}\end{array}$ & $1 \mathrm{~s}$ & Peischl et al. (2012) \\
\hline $\mathrm{CO}$ & $\begin{array}{l}\text { vacuum UV resonance flu- } \\
\text { orescence }\end{array}$ & $5 \%$ & $0.5 \mathrm{ppb}$ & $1 \mathrm{~s}$ & Holloway et al. (2000) \\
\hline $\mathrm{SO}_{2}$ & pulsed UV fluorescence & $20 \%$ & $250 \mathrm{ppt}$ & $1 \mathrm{~s}$ & Ryerson et al. (1998) \\
\hline $\begin{array}{l}\mathrm{NO} \\
\mathrm{NO}_{2} \\
\mathrm{NO}_{y} \\
\mathrm{O}_{3}\end{array}$ & $\begin{array}{l}\text { Gas phase chemilumines- } \\
\text { cence }\end{array}$ & $\begin{array}{l}3 \% \\
4 \% \\
12 \% \\
2 \%\end{array}$ & $\begin{array}{l}10 \mathrm{ppt} \\
30 \mathrm{ppt} \\
40 \mathrm{ppt} \\
15 \mathrm{ppt}\end{array}$ & $1 \mathrm{~s}$ & $\begin{array}{l}\text { Pollack et al. (2010), } \\
\text { Ryerson et al. (1998), } \\
\text { Ryerson et al. (1999) }\end{array}$ \\
\hline Various VOCs & $\begin{array}{l}\text { PTR-MS: proton transfer } \\
\text { reaction mass spectrometer } \\
\text { using } \mathrm{H}_{3} \mathrm{O}^{+} \text {as reagent ion }\end{array}$ & $25 \%$ & $\begin{array}{l}\text { depending on sig- } \\
\text { nal and species }\end{array}$ & $1 \mathrm{~s}$ every $17 \mathrm{~s}$ & $\begin{array}{l}\text { de Gouw and } \\
\text { Warneke (2007) }\end{array}$ \\
\hline $\begin{array}{l}\text { Hydrocarbons, } \\
\text { oxygenated VOCs }\end{array}$ & $\begin{array}{l}\text { iWAS: whole air sampler } \\
\text { with immediate GC-MS } \\
\text { analysis }\end{array}$ & $12-20 \%$ & $\begin{array}{l}4-7 \mathrm{ppt} \\
\mathrm{ppt} \\
\mathrm{ppt}\end{array}$ & $\begin{array}{l}\text { 72/flight } \\
(3-8 \mathrm{~s})\end{array}$ & $\begin{array}{l}\text { Gilman et al. (2009), Lerner } \\
\text { et al. (2016) }\end{array}$ \\
\hline $\begin{array}{l}\mathrm{HNO}_{3} \\
\mathrm{HCOOH} \\
\mathrm{HONO}\end{array}$ & $\begin{array}{l}\mathrm{HNO}_{3} \text {-CIMS: } \\
\text { ionization mass spectrom- } \\
\text { eter with } \mathrm{I}^{-} \text {as reagent } \\
\text { ion }\end{array}$ & $\begin{array}{l}20 \%+50 \mathrm{ppt} \\
20 \%+120 \mathrm{ppt} \\
40 \%+30 \mathrm{ppt}\end{array}$ & $\begin{array}{l}25 \mathrm{ppt} \\
40 \mathrm{ppt} \\
25 \mathrm{ppt}\end{array}$ & $1 \mathrm{~s}$ & Neuman et al. $(2002,2003)$ \\
\hline $\mathrm{NH}_{3}$ & $\begin{array}{l}\mathrm{NH}_{3} \text {-CIMS: chemical ion- } \\
\text { ization mass spectrometer } \\
\text { with protonated acetone } \\
\text { dimers as reagent ion }\end{array}$ & $\begin{array}{l}25 \%+(0.02- \\
0.5) \mathrm{ppb} \\
\text { (depending on } \\
\text { flight) }\end{array}$ & $\begin{array}{l}0.02-0.07 \mathrm{ppb} \\
\text { (depending on } \\
\text { flight) }\end{array}$ & $1 \mathrm{~s}$ & $\begin{array}{l}\text { Neuman et al. (2003), } \\
\text { Nowak et al. (2007) }\end{array}$ \\
\hline $\begin{array}{l}\text { PAN } \\
\text { PPN } \\
\mathrm{APAN} \\
\mathrm{ClNO}_{2}\end{array}$ & $\begin{array}{l}\text { PAN-CIMS: chemical ion- } \\
\text { ization mass spectrometry } \\
\text { with } \mathrm{I}^{-} \text {as reagent ion }\end{array}$ & $\begin{array}{l}0.04-0.05 \mathrm{ppb} \\
0.04-0.1 \mathrm{ppb} \\
0.01-0.02 \mathrm{ppb} \\
0.01-0.02 \mathrm{ppb}\end{array}$ & $\begin{array}{l}0.01 \mathrm{ppb} \\
0.003 \mathrm{ppb} \\
0.006 \mathrm{ppb} \\
0.02 \mathrm{ppb}\end{array}$ & $2 \mathrm{~s}$ & $\begin{array}{l}\text { Osthoff et al. (2008), } \\
\text { Slusher et al. (2004), } \\
\text { Zheng et al. (2011) }\end{array}$ \\
\hline $\begin{array}{l}\text { Various oxygenated } \\
\text { VOCs } \\
\mathrm{ClNO}_{2} \\
\mathrm{~N}_{2} \mathrm{O}_{5} \\
\text { Alkyl nitrates }\end{array}$ & $\begin{array}{l}\text { UW HR-ToF-CIMS: chem- } \\
\text { ical ionization mass spec- } \\
\text { trometer with } \mathrm{I}^{-} \text {as reagent } \\
\text { ion }\end{array}$ & $50 \%$ & $\begin{array}{l}\text { depending on sig- } \\
\text { nal and species }\end{array}$ & $1 \mathrm{~s}$ & Lee et al. (2014) \\
\hline $\begin{array}{l}\text { glyoxal } \\
\mathrm{NO}_{2}\end{array}$ & $\begin{array}{l}\text { ACES: cavity enhanced ab- } \\
\text { sorption spectroscopy }\end{array}$ & $\begin{array}{l}5.8 \% \\
5 \%\end{array}$ & $\begin{array}{l}34 \mathrm{pptv} \\
80 \mathrm{ppt}\end{array}$ & $\begin{array}{l}10 s \\
5 s\end{array}$ & $\begin{array}{l}\text { Min et al. (2016), } \\
\text { Washenfelder et al. (2011b) }\end{array}$ \\
\hline $\begin{array}{l}\mathrm{NO} \\
\mathrm{NO}_{2} \\
\mathrm{O}_{3} \\
\mathrm{NO}_{3} \\
\mathrm{~N}_{2} \mathrm{O}_{5}\end{array}$ & $\begin{array}{l}\text { CRDS: cavity ring-down } \\
\text { absorption spectrometer }\end{array}$ & $\begin{array}{l}5 \% \\
5 \% \\
10 \% \\
20 \% \\
12 \%\end{array}$ & $\begin{array}{l}1 \mathrm{ppbv} \\
0.2 \mathrm{ppbv} \\
0.2 \mathrm{ppbv} \\
3 \mathrm{pptv} \\
3 \mathrm{pptv}\end{array}$ & $1 \mathrm{~s}$ & $\begin{array}{l}\text { Dube et al. (2006), } \\
\text { Wagner et al. (2011) }\end{array}$ \\
\hline $\mathrm{HCHO}$ & $\begin{array}{l}\text { In Situ Airborne Formalde- } \\
\text { hyde (ISAF): laser induced } \\
\text { fluorescence }\end{array}$ & $10 \%$ & $36 \mathrm{ppt}$ & $1 \mathrm{~s}$ & $\begin{array}{l}\text { Cazorla et al. (2015), } \\
\text { DiGangi et al. (2011), } \\
\text { Hottle et al. (2009) }\end{array}$ \\
\hline$j_{\mathrm{NO}_{2}}$ and $j \mathrm{O} 1 \mathrm{D}$ & $j$-heads: filter radiometers & $10 \%$ & & $1 \mathrm{~s}$ & \\
\hline
\end{tabular}

quantification of its output was not available (Veres et al., 2010). Cross calibrations were not conducted between the two instruments during the campaign and therefore do not allow direct comparisons of instrument sensitivity on a flightto-flight basis. Nevertheless, the variability between the two measurements is within the combined uncertainties of the two instruments $\left( \pm 20 \%\right.$ for $\mathrm{HNO}_{3}$-CIMS and $\pm 50 \%$ for UW HR-ToF-CIMS).

During the night flights two instruments measured $\mathrm{CINO}_{2}$ : the UW HR-ToF-CIMS and the PAN-CIMS and $\mathrm{N}_{2} \mathrm{O}_{5}$ was measured with the UW HR-ToF-CIMS and CRDS. The comparison is shown in Fig. 6 as time series and scatter plots for 


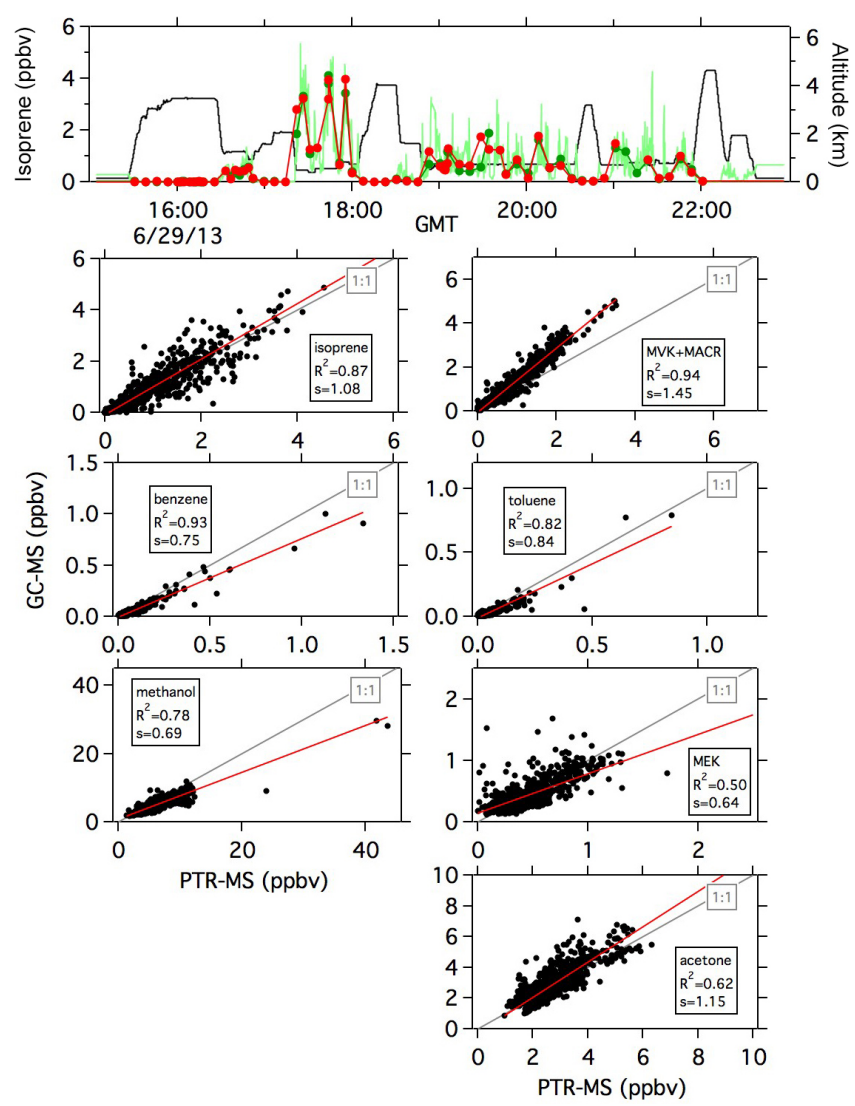

Figure 4. Inter-comparison between PTR-MS and iWAS/GCMS.

the flight on 3 July 2013. The slopes are 1.19 and 0.91 and the $R^{2} 0.74$ and 0.92 , respectively. For small signals such as $\mathrm{ClNO}_{2}$, the signal to noise of the UW HR-ToF-CIMS is aided by its ability to distinguish isobaric contaminants from halogen containing molecules, which have a distinct mass defect (Kercher et al., 2009; Lee et al., 2014). The scatter plot displays some non-linearity and the $\mathrm{N}_{2} \mathrm{O}_{5}$ is just outside the range of a previous comparison (Chang et al., 2011), but the results are within the combined uncertainties of the instruments given in Table 6.

Figure 7 shows the $\mathrm{NO}_{y}$ budget for all the individually measured $\mathrm{NO}_{y}$ species compared to the measured total $\mathrm{NO}_{y}$ for the NOAA WP-3D flight on 16 June 2013. Aerosol nitrate might contribute about $2 \%$ to the sum. This assumes a quantitative sampling and conversion of aerosol nitrate. This is likely not the case and $\mathrm{NO}_{y}$ from aerosol nitrate is likely an upper limit, and the data are shown with and without the potential aerosol contribution. The highest mixing ratios of $\mathrm{NO}_{y}$ are observed in power plant plumes, where most $\mathrm{NO}_{y}$ consists of $\mathrm{NO}_{x}$. For a more detailed comparison the $\mathrm{NO}_{z}$ $\left(=\mathrm{NO}_{y}-\mathrm{NO}_{x}\right)$ budget is shown in Fig. 7 as well. The power plant plumes were removed for this comparison by looking at the location of the power plants, the wind direction and the large increases in $\mathrm{NO}_{x}$ downwind of the power plants were removed from the data in Fig. 7. In those plumes the time
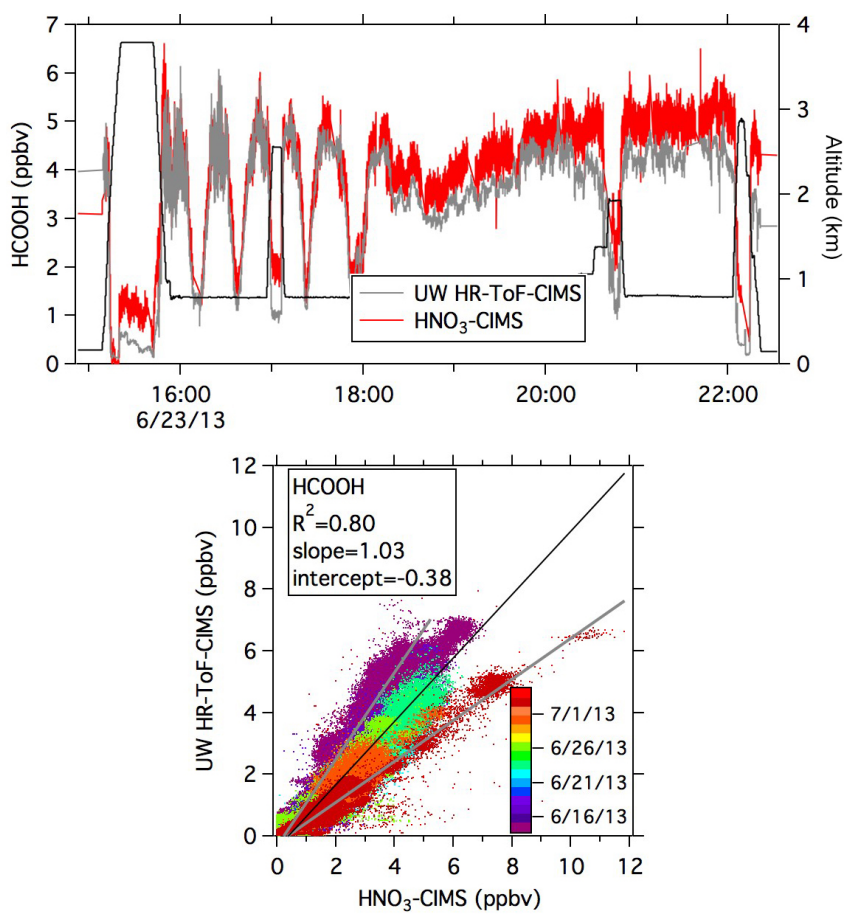

Figure 5. $\mathrm{HCOOH}$ inter-comparison between the $\mathrm{HNO}_{3}$-CIMS and the UW HR-ToF-CIMS as a time series for a selected flight and a scatter plot. The color code in the scatter plot indicates all the individual flights. The black line is a fit using all the data the grey lines fits for individual flights with the highest or lowest slope, respectively.

resolution and the accuracy of $\mathrm{NO}_{y}$ and $\mathrm{NO}_{x}$ are not high enough to calculate small differences in $\mathrm{NO}_{z}$ during these periods with very high $\mathrm{NO}_{x}$ mixing ratios. On this flight the sum of individually measured $\mathrm{NO}_{y}$ constituents was roughly $90 \%$ of the total measured as $\mathrm{NO}_{y}$, similar to the whole campaign $\mathrm{NO}_{y}$ budget. The unmeasured $\mathrm{NO}_{y}$ outside power plants was about $25 \%$ (or $15 \%$, when including aerosol nitrate). Organic nitrates derived from the oxidation of isoprene and monoterpene have been detected by Lee et al. (2014) during SENEX and these compounds will contribute to the missing fraction of individual $\mathrm{NO}_{y}$ constituents, but total organic nitrates have not been quantified during SENEX and were not added to the sum of individually measured $\mathrm{NO}_{y}$ constituents.

The aerosol volume derived from the chemical composition data (AMS and SP2) was compared to the volume derived from the measured size distributions, following Middlebrook et al. (2012). All of these measurements sampled aerosol downstream of a 1 micron impactor. For each $10 \mathrm{~s}$ AMS measurement, the composition-derived volume was calculated by adding the average $\mathrm{rBC}$ mass from the SP2 instrument to the AMS total aerosol mass and dividing it by the density estimated from the AMS and BC composition. The mass-weighted density $(\rho)$ was calculated using 

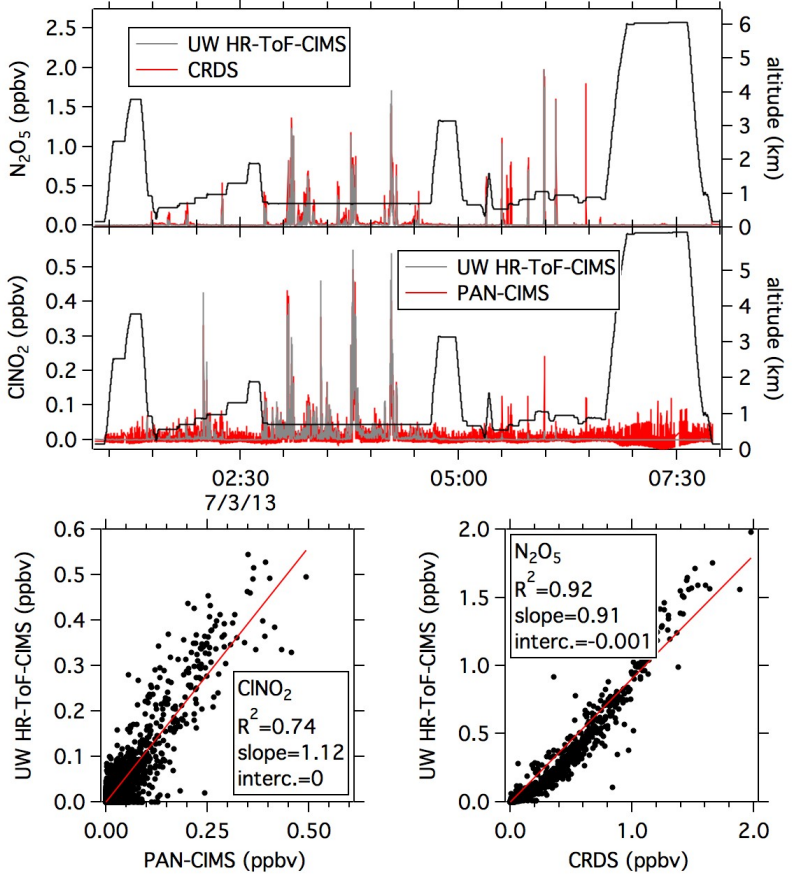

Figure 6. Inter-comparison between the UW HR-ToF-CIMS of $\mathrm{N}_{2} \mathrm{O}_{5}$ with $\mathrm{CRDS}$ and $\mathrm{ClNO}_{2}$ with the PAN-CIMS as time series and scatter plots for the nighttime flight on 3 July 2013.

$\rho_{\text {org }}=1.25 \mathrm{~g} \mathrm{~cm}^{-3}$ (Cross et al., 2007; Kiendler-Scharr et al., 2009; Zelenyuk et al., 2008), $\rho_{\text {inorg }}=1.75 \mathrm{~g} \mathrm{~cm}^{-3}$ (primarily dry ammonium sulfate, Perry and Green, 1997), and $\rho_{\mathrm{BC}}=1.8 \mathrm{~g} \mathrm{~cm}^{-3}$ (Park et al., 2004), for organic mass, inorganic mass, and $\mathrm{BC}$, respectively. The measured AMS lens transmission curve (Bahreini et al., 2008) was applied to the particle number distributions to account for particle transmission losses in the AMS lens before calculating the volume from the size distributions, which were also averaged over the AMS sampling time. For this field project, the fraction of aerosol volume behind the 1 micron impactor that was transmitted into the AMS instrument by the lens was on average $99 \%$ with a minimum of $92 \%$.

The slope of the composition-derived volume vs. the volume calculated from the size distributions with available data are shown in Fig. 8 as a function of flight date color coded with the linear correlation coefficient $R^{2}$. The grey bands indicate the overall combined $2 \sigma$ uncertainty of $\pm 60 \%$ (Bahreini et al., 2009; Brock et al., 2011; Schwarz et al., 2006). The volumes from most of the flights agree within this combined uncertainty and with $R^{2}$ values between 0.62 to 0.98 , indicating that most of the aerosol in the AMS lens transmission size range was composed of non-refractory material and black carbon. Only the slopes for flights on 29 June 2013 was outside the uncertainty band. We note that $\mathrm{rBC}$ only contributed $1 \%$ on average to the total accumula-
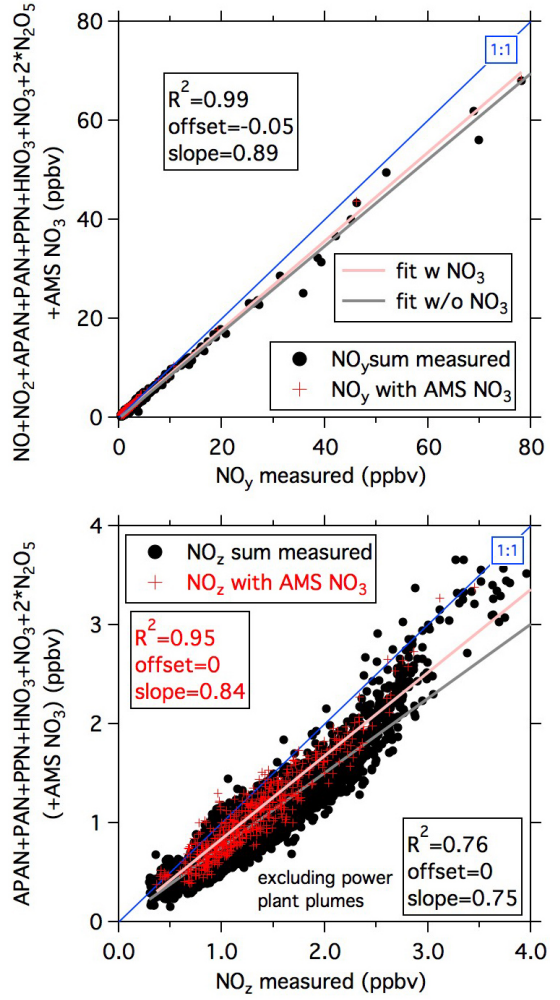

Figure 7. $\mathrm{NO}_{y}$ and $\mathrm{NO}_{z}\left(=\mathrm{NO}_{y}-\mathrm{NO}_{x}\right)$ budgets for the NOAA WP-3D flight on 16 June 2013 with and without aerosol nitrate.

tion mode mass, and in 1 min averages only exceeded $3 \%$ less than $1 \%$ of the time during SENEX.

On 29 June 2013 the NOAA WP-3D and the NSF NCAR C-130 did coordinated wing-to-wing flight legs in the free troposphere and the boundary layer for an inter-comparison in southern Tennessee and northern Alabama with a duration of just over $1 \mathrm{~h}$. Several over-flights over the SOAS ground site in Centreville were performed during SENEX. Results of the platform inter-comparisons will not be presented here.

\section{Example Flight on 16 June 2013 near Atlanta, GA}

Results from the SENEX research flight on 16 June 2013 are presented here to demonstrate the strategy used to address many of the SENEX science questions such as the determination of anthropogenic and biogenic emissions, and the subsequent atmospheric chemistry, transformation, and production of secondary species. Flights over the shale gas regions will not be discussed here, but calculations of the methane emission fluxes from the three shale gas regions can be found elsewhere (Peischl et al., 2015; Yuan et al., 2015). The major goal of the 16 June 2013 flight was to investigate the Atlanta urban plume and the Scherer and Harllee Branch power plant plumes as they were transported over heavily forested areas in Georgia with strong biogenic emissions. 

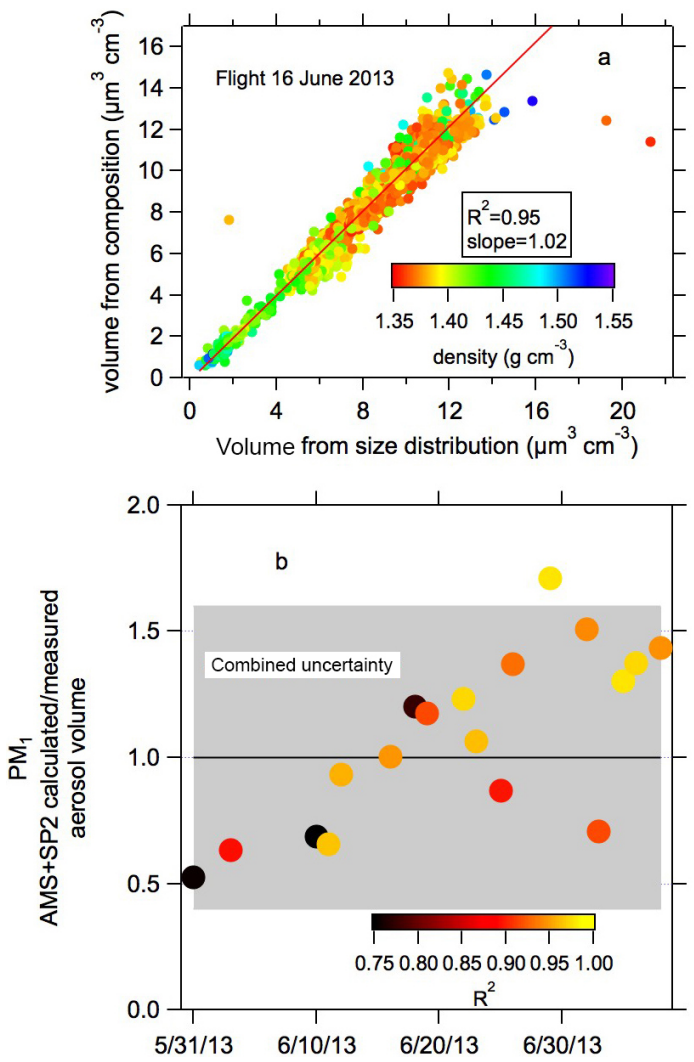

Figure 8. The aerosol volume derived from the chemical composition data (AMS and SP2) was compared to the volume from the size distribution data (NMASS and UHSAS). (a) The correlation for the flight on 16 June 2013 color-coded by the density. (b) The slopes for all the flights color-coded by the respective correlation coefficient determined as shown in (a).

\subsection{Anthropogenic, biogenic, and point source emissions}

Figure 9a shows the WP-3D flight track over Atlanta and surrounding areas color-coded by $\mathrm{NO}_{y}$ on top of a map showing anthropogenic emission sources, which are the urban areas and point sources: power plants, landfills, paper mills, and coal mines. Other point sources studied that are not shown on this map include biofuel refineries (de Gouw et al., 2015a). The point sources are sized by their respective emission strengths or capacity. The flight included eight tracks perpendicular to the wind direction (numbered 0-7 in Fig. 9a): one upwind of Atlanta, three over the metro area and four downwind. The flight tracks were set such that the distance between each leg represents about $1 \mathrm{~h}$ of transport at the prevailing wind speed and also such that many of the point source plumes were intercepted.

Figure 10 shows results for the intercepts of such point source plumes. In Fig. 10a the methane measurements along transect 4 downwind of the Pine Bluff landfill in Georgia are shown. Landfills are an important source of methane in the
US, but they do not emit many other compounds and indeed methane was the only species measured aboard the WP-3D payload that showed a detectable enhancement in the plume. The forested southeastern US is heavily managed for largescale wood and wood products and therefore has a large density of pulp and paper mills. Pulp and paper mills use a significant amount of energy, which they often produce partially on site. For example the investigated facility has four steam producing boilers at close to $80 \mathrm{MWh}$ that mainly burn coal, natural gas, oil and wood/bark waste biomass. The power production results in emissions of the combustion species NO, $\mathrm{NO}_{2}, \mathrm{CO}, \mathrm{SO}_{2}$ and $\mathrm{CO}_{2}$ (only $\mathrm{NO}$ is shown in Fig. 10b). The paper mill plumes were intercepted on transect 0 during this flight. High mixing ratios of monoterpenes, methanol and acetaldehyde were also observed downwind of those facilities (Fig. 10b).

US urban emissions, and therefore urban mixing ratios of many air pollutants have decreased significantly over the last few decades (Dallmann and Harley, 2010; Emmons et al., 2015; von Schneidemesser et al., 2010; Warneke et al., 2012). For example, Warneke et al. (2012) analyzed 50 years of ambient measurements and found that VOCs and $\mathrm{CO}$ have decreased at an annual rate of about $7.5 \%$ in Los Angeles, CA. Blanchard et al. (2013) analyzed Southeastern Aerosol Research and Characterization (SEARCH) network data and found downward trends in ambient carbon monoxide $(\mathrm{CO})$, sulfur dioxide $\left(\mathrm{SO}_{2}\right)$, and oxidized nitrogen species $\left(\mathrm{NO}_{y}\right)$ concentrations averaged $1.2 \pm 0.4$ to $9.7 \pm 1.8 \%$ per year from 1999 to 2010. The NOAA WP-3D flew over Atlanta, GA during SOS (Southern Oxidant Study 1999) on 6 July 1999 and the results are shown in Fig. 11 and are compared to the SENEX 16 June 2013 data. These two days were comparable in meteorological conditions with wind speeds around $4 \mathrm{~m} \mathrm{~s}^{-1}$, temperatures around $26^{\circ} \mathrm{C}$ in the boundary layer, and boundary layer heights of about $1.6 \mathrm{~km}$ on 6 July 1999 and $1-1.2 \mathrm{~km}$ on 16 June 2013. The flight track on top of the map color coded with $1999 \mathrm{NO}_{y}$ has the same color scale as the flight on 16 June 2013 shown in Fig. 9 and clearly shows qualitatively that the pollution was more intense and widespread. The time series of $\mathrm{CO}$ and $\mathrm{NO}_{y}$ for the two flights in Fig. 11 are consistent with significant emissions decreases between 1999 and 2013. It is expected that the comparison between the 1999 and 2013 airborne data sets will provide important insights and evidence to answer the main science questions from SENEX.

\subsection{Coal and natural gas fired power plant plumes}

During SENEX several power plant plumes were sampled. Figure 12 shows the flight track from the 22 June 2013 over Atlanta that included transects downwind of the coal fired Bowen and the natural gas combined cycle McDonough power plants. The emission intensities of these two different kinds of power plants are very different; combined cycle natural gas power plant have much lower $\mathrm{CO}_{2}, \mathrm{SO}_{2}$ and $\mathrm{NO}_{x}$ 

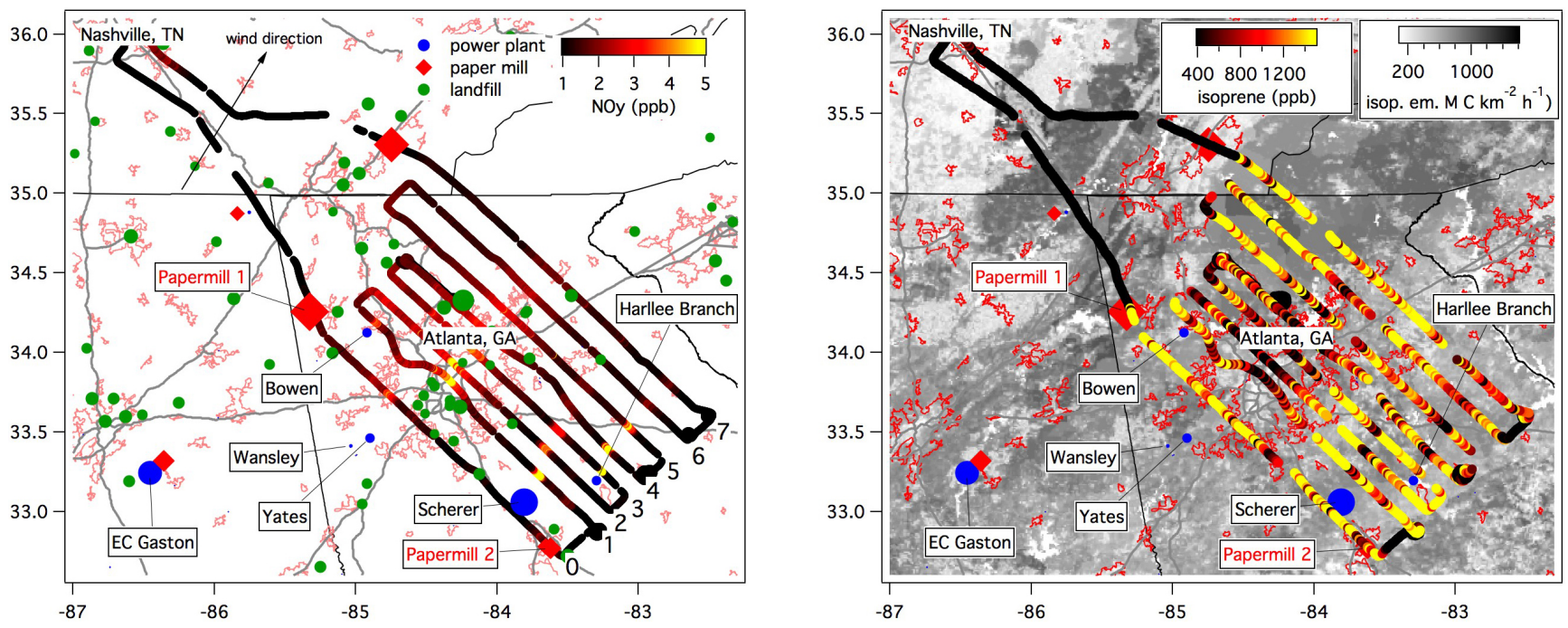

Figure 9. The flight track of the NOAA WP-3D on 16 June 2013 over Atlanta, GA color coded with $\mathrm{NO}_{y}$ in the top panel and with isoprene on the bottom panel. The underlying maps show the point source emissions (power plants, paper mills and land fills) in the top panel and the isoprene emissions potential in the bottom panel.
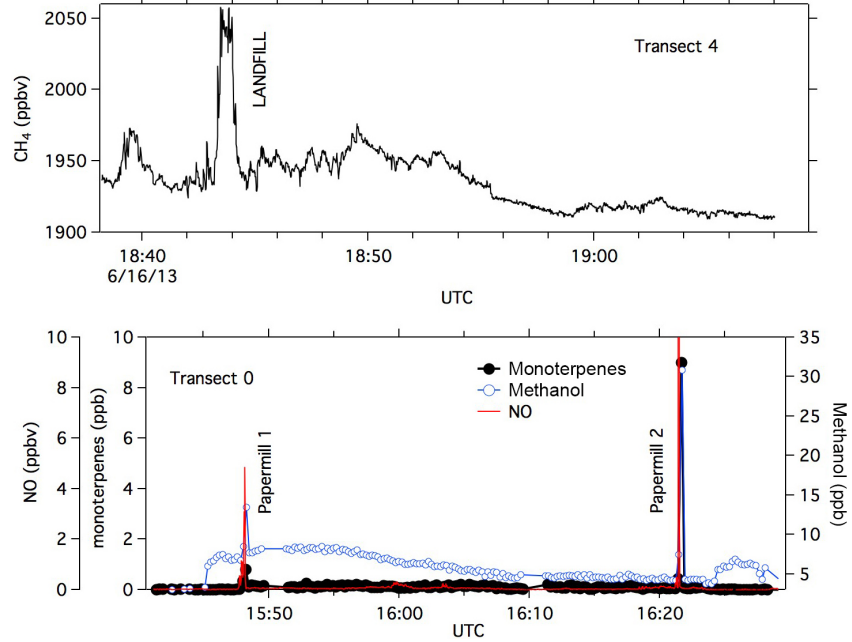

Figure 10. Time series of two transects during the 16 June 2013 flight downwind of a landfill and two paper mills.

emissions per unit energy produced than coal fired power plants (de Gouw et al., 2014). The Bowen power plant produced 3.3 TWh and McDonough 4.7 TWh in the 1st quarter of 2013. According to the continuous emissions monitoring systems (CEMS) monitoring data, during the 1st quarter of 2013 the Bowen power plant emitted $930 \mathrm{~g} \mathrm{kWh}^{-1}$ $\mathrm{CO}_{2}, 0.20 \mathrm{~g} \mathrm{kWh}^{-1} \mathrm{SO}_{2}$ and $0.56 \mathrm{~g} \mathrm{kWh}^{-1} \mathrm{NO}_{x}$, while McDonough emitted $360 \mathrm{~g} \mathrm{kWh}^{-1} \mathrm{CO}_{2}, 0.0019 \mathrm{~g} \mathrm{kWh}^{-1} \mathrm{SO}_{2}$ and $0.018 \mathrm{~g} \mathrm{kWh}^{-1} \mathrm{NO}_{x}$. These large differences in emission intensities are clearly reflected in the enhancements measured in the downwind transects shown in Fig. 12. In the Bowen power plant plume about $20 \mathrm{ppmv} \mathrm{CO}_{2}, 5 \mathrm{ppbv}$
$\mathrm{NO}_{y}$ and 4 ppbv $\mathrm{SO}_{2}$ enhancements were observed, while the McDonough plume had only about 5 ppmv of $\mathrm{CO}_{2}$ enhancement and $\mathrm{SO}_{2}$ and $\mathrm{NO}_{y}$ were not measurably enhanced above background. To account for the different dilutions during transport $(5 \mathrm{~km}$ distance for Bowen and $10 \mathrm{~km}$ for McDonough at about $3 \mathrm{~m} \mathrm{~s}^{-1}$ average wind speed) enhancement ratios need to be considered. In the Bowen plume $0.24 \mathrm{ppb} \mathrm{ppm}^{-1}$ of $\mathrm{NO}_{y} / \mathrm{CO}_{2}$ and $0.13 \mathrm{ppb} \mathrm{ppm}^{-1}$ of $\mathrm{SO}_{2} / \mathrm{CO}_{2}$ were measured. Because no enhancements in the McDonough plume were seen, enhancement ratios cannot be determined, but using a $S / N=2$ the upper limit for enhancement ratios in the McDonough plume are $0.06 \mathrm{ppb} \mathrm{ppm}^{-1}$ for of $\mathrm{NO}_{y} / \mathrm{CO}_{2}$ and $0.11 \mathrm{ppb} \mathrm{ppm}^{-1}$ for $\mathrm{SO}_{2} / \mathrm{CO}_{2}$ are determined. This shows that the $\mathrm{NO}_{y}$ and $\mathrm{SO}_{2}$ enhancements in the gas fired McDonough plant are clearly smaller than in the coal fired Bowen plant. In addition to investigating emissions from the power plant plumes as was shown here, the emissions of those power plants mix with the large emissions of isoprene in this area as can be seen in Fig. 9. This provides an ideal case for studying the interactions between natural and anthropogenic emissions. The chemistry of isoprene, $\mathrm{OH}$, formaldehyde and $\mathrm{NO}_{x}$ in power plant plumes and other areas during SENEX will be described in detail elsewhere (de Gouw et al., 2015b; Kaiser et al., 2015; Wolfe et al., 2015). 

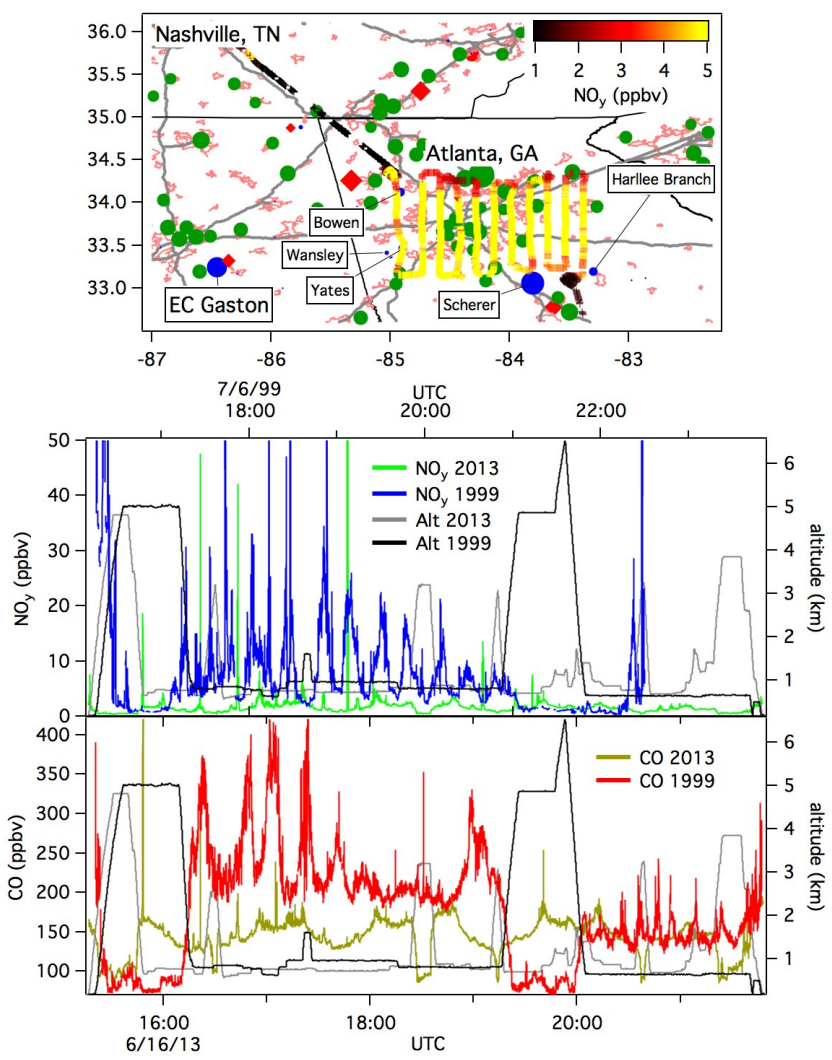

Figure 11. The track of a flight on 6 July 1999 over Atlanta during the SOS99 campaign color-coded with the $\mathrm{NO}_{y}$ mixing ratio. Time series of the 16 June 2013 and the 6 July 1999 flights for $\mathrm{NO}_{y}$ and $\mathrm{CO}$ show that the mixing ratios over Atlanta have decreased significantly over the past 14 years.

\subsection{Modeling support for SENEX}

During SENEX various models were available that delivered outputs along the flight tracks of the WP-3D aircraft: the NOAA AM3 model (Li et al., 2016; Wolfe et al., 2016) (http://esrl.noaa.gov/csd/projects/senex/), an MCM-based 0D box model (Wolfe et al., 2016), WRF-Chem (Weather Research and Forecasting with Chemistry) and FLEXPARTWRF (Angevine et al., 2014) simulations and the Lagrangian particle dispersion model FLEXPART (Stohl et al., 2005).

Here we show results of one of those models as an example. Figure 13 shows the modeling support for SENEX from the FLEXPART model. To simulate air pollution transport, the FLEXPART Lagrangian particle dispersion model (Stohl et al., 2005) was used. This model has been used successfully in the past to simulate the transport of anthropogenic emissions or biomass burning plumes. FLEXPART was driven by meteorological data from the National Centers for Environmental Prediction (NCEP) Global Forecast System (GFS) with a temporal resolution of $3 \mathrm{~h}$ (analyses at 00:00, 06:00, 12:00, 18:00 UTC; $3 \mathrm{~h}$ forecasts at 03:00, 09:00, 15:00,
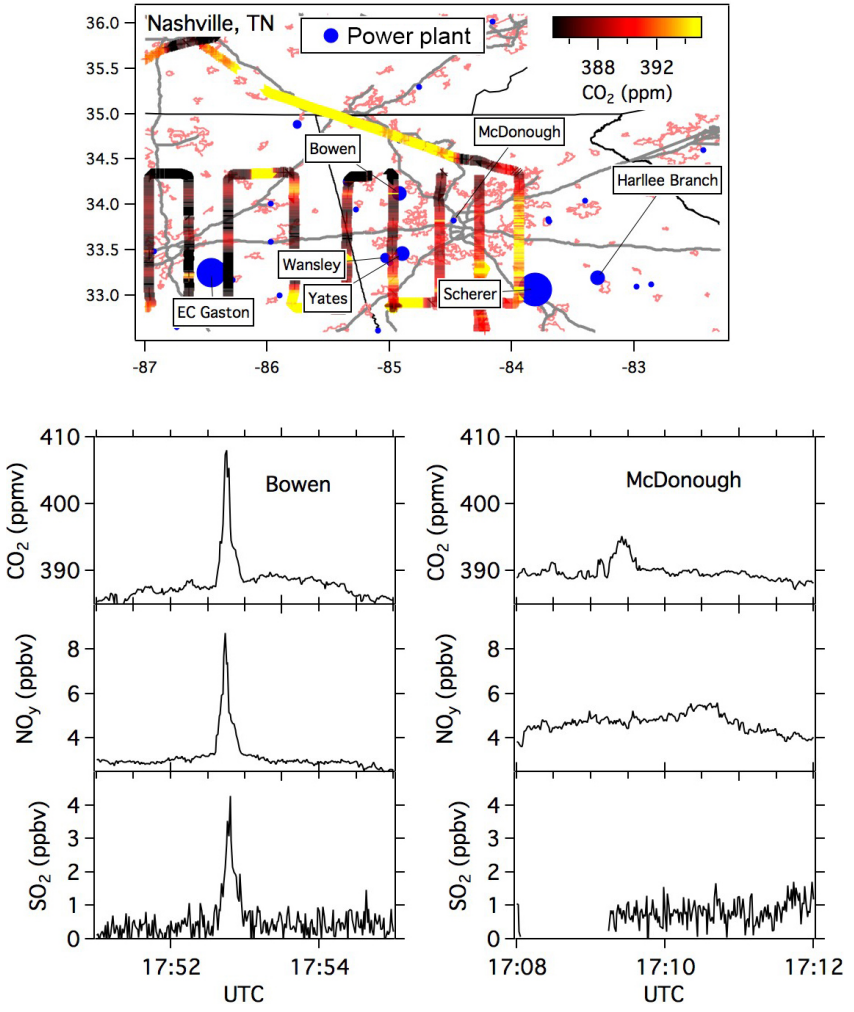

Figure 12. The track from the 22 June 2013 flight over Atlanta color-coded with the $\mathrm{CO}_{2}$ mixing ratio. Transects downwind of the coal fired Bowen and the natural gas combined cycle McDonough power plants.

21:00 UTC) and 26 pressure levels. Horizontal resolution was $0.5 \times 0.5^{\circ}$ globally. The emission and atmospheric transport of anthropogenic sources was computed using anthropogenic $\mathrm{CO}$ and $\mathrm{NO}_{x}$ emissions from the EPA $2005 \mathrm{Na}-$ tional Emission Inventory for sources in North America, and EDGAR for sources in Asia. A passive biomass burning CO tracer was calculated using MODIS satellite fire detections and the algorithm of Stohl et al. (2007), which uses fire detection data, information on land use and applies emission factors from Andreae and Merlet (2001). The biomass burning injection height was prescribed relatively to the local planetary boundary layer height, following the injection height statistic in Brioude et al. (Brioude et al., 2009). The tracers were advected in the model for 20 days. The FLEXPART model output can be accessed at http://www.esrl.noaa.gov/ csd/groups/csd4/forecasts/senex/.

To estimate the surface origin of air masses measured by the NOAA P3 aircraft, surface contribution maps were calculated using FLEXPART-WRF back trajectories (Brioude et al., 2013) driven by the WRF mesoscale model output at $12 \times 12 \mathrm{~km}$ resolution available every hour. 20000 particles were released from locations along the flight tracks every $20 \mathrm{~s}$, and tracked back in time for 10 days. The model outputs the residence time of the particles in a volume such as 

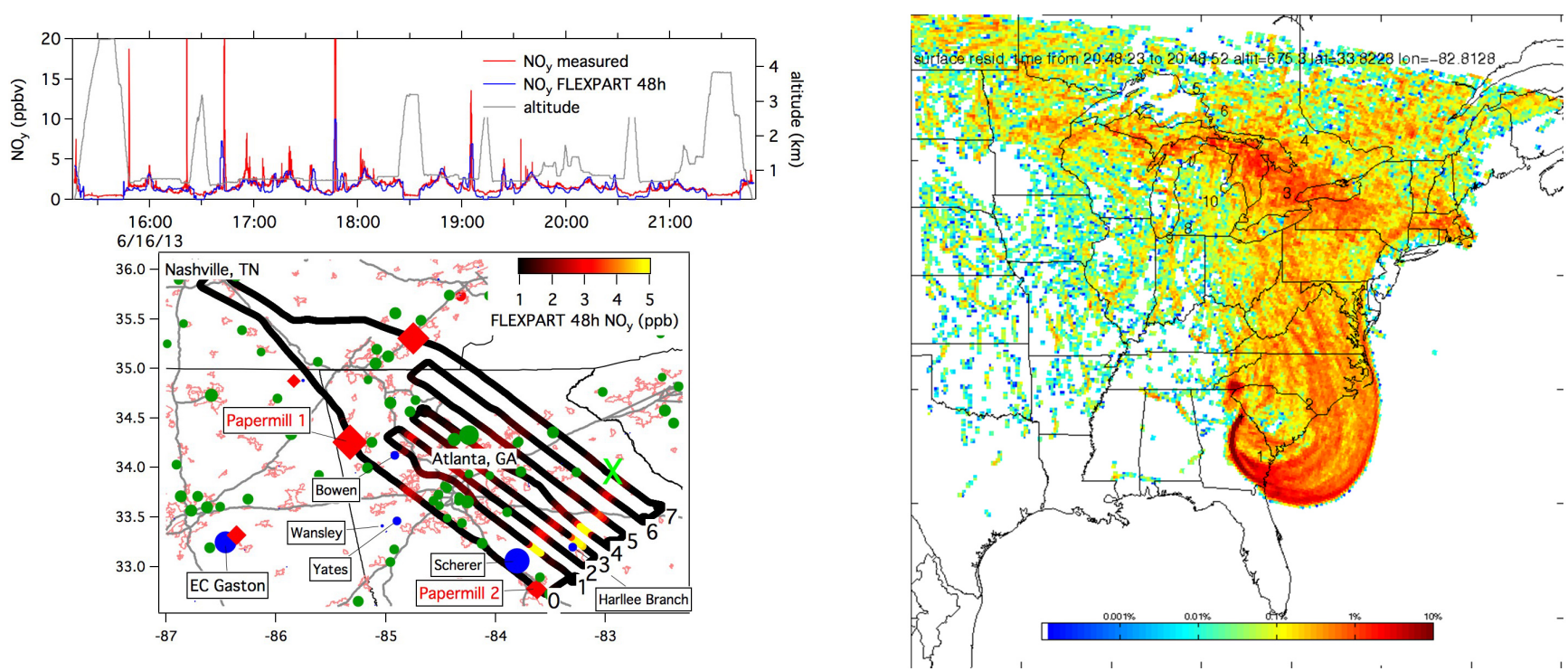

Figure 13. FLEXPART model results: time series of $\mathrm{NO}_{y}$ with $48 \mathrm{~h}$ of accumulation time, the flight track color-coded by modeled $\mathrm{NO}_{y}$ and the surface residence time for a point on the last transect downwind of the Harllee Branch power plant.

the surface layer. By multiplying the footprint with gridded emission fluxes the model calculates the mixing ratio of the emitted species at the location of the aircraft. All species are considered as conserved tracers; the model does not contain chemical transformations, but it does keep track of the time since emission. As an example, Fig. 13a and $\mathrm{b}$ show the time series of FLEXPART $\mathrm{NO}_{y}$ (accumulating emissions from the previous $48 \mathrm{~h}$ ) together with the flight track color coded with $\mathrm{NO}_{y}$. Comparing the modeled and measured $\mathrm{NO}_{y}$ in Figs. 13a and 9, it can be seen that the model reproduces the time series qualitatively, including the broader features and the power plant plume encounters. The very high mixing ratios in the narrow power plant plumes are underestimated in the model (the plumes are too narrow for the model resolution). The footprint map for a point along the last flight track downwind of the Harllee Branch power plant plume is shown in Fig. 13c showing that the mixing ratios at this point along the flight track will have the highest contribution from the immediate upwind area that includes the Harllee Branch power plant, just as expected. But there was also a significant contribution to the mixing ratios from long-range transport from the Northeast US. Other available FLEXPART model outputs include $\mathrm{CO}$, biomass burning $\mathrm{CO}, \mathrm{SO}_{2}$, isoprene and monoterpenes.

\section{Summary}

The Southeast Atmosphere Study (SAS) was a large collaborative and community effort to understand the air quality and climate issues in the southeastern United States. This paper provides a summary of the experimental setup for the NOAA-led SENEX study, which was an important component of the SAS. The NOAA WP-3D aircraft capabilities, the payload, instrument descriptions, inter-comparisons and flight locations and goals are described in detail in this paper. The flight on 16 June 2013 in the Atlanta area was described in some detail to demonstrate the strategies used during SENEX to study the air quality and climate relevant interactions of biogenic and anthropogenic emissions in the southeastern US, which was one of the main foci of the SAS study. 
Appendix A: Detailed descriptions of instruments on the NOAA WP-3D

\section{A1 Aerosol particle size distributions: PI Charles Brock}

The NOAA ESRL (Earth System Research Laboratory) cloud and aerosol processes group operated three instruments that together provided the concentration of particles as a function of their dry size from 0.004 to $7.0 \mu \mathrm{m}$ diameter. The size distribution is a fundamental property of the atmospheric aerosol, and it contributes to understanding aerosol sources and sinks, optical properties, cloud nucleation potential, and chemical transformations.

Particles with diameters from $\sim 0.004$ to $0.07 \mu \mathrm{m}$ were measured with a five-channel condensation particle counter (CPC), the nucleation-mode aerosol size spectrometer (NMASS) (Brock et al., 2000). This unique instrument samples particles into a low-pressure region $(\sim 100 \mathrm{hPa})$, where they are exposed to a warm vapor from a perfluorinated organic compound. The sample airstream is then cooled, producing a supersaturation of the vapor. Particles larger than a critical size are nucleated form a droplet of the organic fluid and are counted with a simple laser optical counter. Each of the five NMASS channels operates at a different temperature, so that the critical diameter varies in each. Particles with diameters larger than $0.004,0.008,0.015,0.030$, and $0.055 \mu \mathrm{m}$ are nucleated and counted independently. Differencing the channels provides a coarse resolution, but fast $(1 \mathrm{~s})$ time response, measurement of the size distribution of ultrafine particles.

Particles with diameters from 0.07 to $\sim 1.0 \mu \mathrm{m}$ were measured by an ultra-high sensitivity aerosol spectrometer (UHSAS) (Brock et al., 2011). The aerosol sample enters a resonant cavity that is driven by a solid-state laser at $1053 \mathrm{~nm}$ wavelength. The size of each particle is determined by measuring the amount of side-scattered light reaching two solidstate photodiode detectors. The instrument was housed in the same rack as the aerosol optical properties (AOPs) instruments, and sampled from the same dried $(<10 \%$ relative humidity, RH) airstream that supplied the optical instruments. The UHSAS has been substantially modified from the commercial laboratory version (Droplet Measurement Technologies, Boulder, Colorado) and has been equipped with an RH control system. The RH of the sample can be switched between the default dry mode and an elevated humidity $(\sim 85 \% \mathrm{RH})$. The change in the aerosol size distribution can be used to evaluate the hygroscopicity of the particles. The humidified and dry size distribution can be used to calculate how aerosol properties, such as directional scattering (asymmetry parameter) vary with atmospheric humidity.

Particles with diameters from $\sim 0.7$ to $7.0 \mu \mathrm{m}$ were measured with a custom-built white-light optical particle counter (WLOPC). This instrument detects light from a 3-watt whitelight-emitting diode (LED) source that is scattered over a wide angle by single particles. The white light source is used to reduce particle sizing biases caused by widely varying particle compositions and shapes that are typical of supermicron aerosol particles. The high sample flow rate of the WLOPC results in acceptable counting statistics for supermicron particles over time periods of $\sim 10 \mathrm{~s}$ at typical coarse particle concentrations. The inlet of the WLOPC is maintained at $<40 \% \mathrm{RH}$ by heating the sample line as necessary.

The UHSAS and WLOPC operated in the WP-3D cabin and sampled air downstream of the low-turbulence inlet (LTI) (Wilson et al., 2004). The LTI actively removes turbulent flow developing along the walls of a conical diffuser. Since the NMASS measures ultrafine particles subject to diffusive rather than inertial losses, it sampled instead from a double diffusing inlet in a non-pressurized wing pod.

\section{A2 Cloud condensation nuclei (CCN): PI Athanasios Nenes}

The Georgia Tech group operated a Continuous Flow Streamwise Thermal Gradient CCN chamber (CFSTGC) (Lance et al., 2006; Roberts and Nenes, 2005) in scanning flow CCN analysis mode (SFCA) (Moore and Nenes, 2009) on the WP-3D during the SENEX mission. The instrument provided CCN spectra, or the number of aerosol that act as cloud condensation nuclei as a function of supersaturation.

The CFSTGC used is made by Droplet Measurement Technologies (CCN-100 SN007, DMT; Lance et al., 2006) and consists of a cylindrical metal tube $(0.5 \mathrm{~m}$ in length with a $23 \mathrm{~mm}$ inner diameter and $10 \mathrm{~mm}$ wall thickness) with a wetted inner wall on which a linear temperature gradient is applied in the stream-wise direction. The temperature gradient is controlled using three thermoelectric coolers (TECs) located on the outer wall of the flow chamber (Fig. A1), and water flows continuously through a $2.5 \mathrm{~mm}$ thick, porous, ceramic bisque that lines the inside of the cylinder. Heat and water vapor diffuse toward the centerline of the flow chamber. Since moist air is largely composed of $\mathrm{N}_{2}$ and $\mathrm{O}_{2}$, which are heavier molecules than $\mathrm{H}_{2} \mathrm{O}$, the latter has a higher molecular velocity, hence diffuses more quickly than heat (which is transferred primary via collisions between slower $\mathrm{N}_{2}, \mathrm{O}_{2}$ ). Under developed flow conditions, a quasi-parabolic water vapor supersaturation is generated in the radial direction, which is maximized at the centerline (Roberts and Nenes, 2005). The aerosol sample enters the top of the column at the centerline and is surrounded by a blanket of humidified, aerosol-free sheath air. If the supersaturation in the instrument exceeds the critical supersaturation of the aerosol, the particles activate and form droplets, which are counted and sized by an optical particle counter (OPC) using a $50 \mathrm{~mW}, 658 \mathrm{~nm}$ wavelength laser diode light source. The droplet concentration is then equal to the concentration of $\mathrm{CCN}$ at the supersaturation considered. The droplet size distribution information obtained in the OPC also allows using 
the CFSTGC to study CCN activation kinetics (Raatikainen et al., 2012, 2013).

The CFSTGC was operated in SFCA (Moore and Nenes, 2009) mode, which allowed rapid, high-resolution measurements of CCN spectra. SFCA is based on varying the instrument flow rate while keeping the instrument pressure and streamwise temperature difference constant. Varying the flow rate at a sufficiently slow rate allows the operation of the instrument at pseudo-steady state, where instantaneous flow rates correspond to an instantaneous supersaturation and greatly facilitates inversion of the $\mathrm{CCN}$ time series to a $\mathrm{CCN}$ spectrum. SFCA overcomes the limitations of operating the CFSTGC under a "constant flow" mode (where the flow rate is maintained at a constant value and supersaturation is adjusted by changing the column temperature gradient in the streamwise direction), requiring $20-120 \mathrm{~s}$ for column temperatures to stabilize during a supersaturation change. During SENEX, flow rate in the CFSTGC in SFCA mode was controlled using a mass flow controller (MKS Instruments model M100B01313CR1BV) with signal to the mass flow controller generated with an Arduino Uno microcontroller board (Lin et al., 2016). CCN spectra were obtained every $60 \mathrm{~s}$, over a supersaturation range of 0.1 to $0.8 \%$. The CCN concentration uncertainty was $\pm 10 \%$ or $5-10 \mathrm{~cm}^{-3}$ under conditions of low counting statistics. The absolute supersaturation uncertainty was $\pm 0.04 \%$ (Moore et al., 2012).

Supersaturation in the instrument is sensitive to pressure fluctuations associated with altitude changes. For this, a DMT pressure control box combined with a custom-built inlet that minimizes particle losses was connected upstream of the CFSTGC (Fig. A1). The device ensured a constant pressure in the CFSTGC, typically set to a value below the minimum ambient pressure encountered during a science flight. Pressure changes also occur within the CCN instrument chamber from flow rate changes during a typical SFCA cycle. This affects the instantaneous supersaturation in the instrument in a reproducible and predictable manner and can be accounted for with calibration (Lin et al., 2016; Raatikainen et al., 2014).

\section{A3 Aerosol optical properties (AOPs)}

The NOAA ESRL cloud and aerosol processes group operated an aerosol optical properties (AOPs) instrument package on the NOAA P3 during the SENEX mission. The AOP package provided multi-wavelength, multi-RH aerosol extinction and absorption measurements with fast response and excellent accuracy and stability on aircraft platforms. The instruments also characterized the optics of black carbon (BC) mixing state, brown carbon, and water uptake of aerosol. Two instruments, a cavity ring-down (CRD) aerosol extinction spectrometer and a photoacoustic absorption spectrometer (PAS) comprised the AOP package.

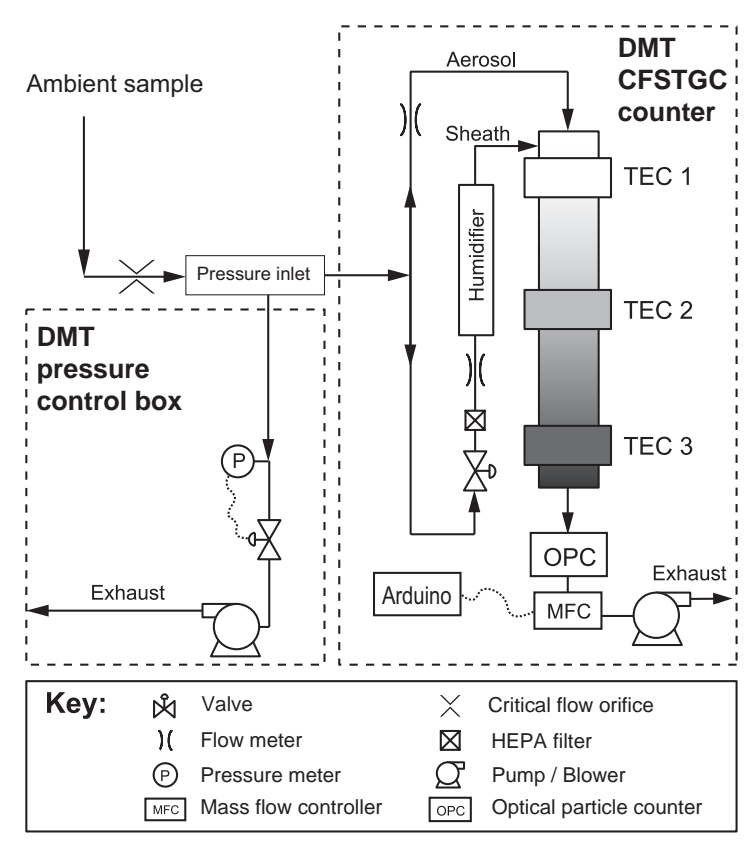

Figure A1. Instrument setup for measuring $\mathrm{CCN}$ spectra during SENEX.

\section{A3.1 Cavity ring-down aerosol extinction spectrometer (CRD): PI Justin Langridge, Nick Wagner}

The CRD instrument (Langridge et al., 2011) is composed of 8 separate ring-down cavities (Fig. A2). Each channel of the instrument consists of a sample cell located between two highly reflective mirrors, which form an optical cavity with effective path lengths ranging from 7 to $60 \mathrm{~km}$ in particlefree air. A laser is used to periodically inject light into the cavity and the optical power in the cavity decays exponentially after the laser turned off. Light leaking through the back mirror of the cavity is used to monitor the decay. The time constant of the exponential decay is proportional to the total extinction coefficient of the optical cavity. The extinction due to aerosol is measured using the difference in the extinction when aerosol is present or absent from the sample cell. Before entering the sample cell, the aerosol is dried using a Nafion drier (Permapure PD-200T-12-MSS, Toms River, New Jersey, USA), and gas-phase absorbers are removed using an activated carbon monolith (MAST Carbon NovaCarb F, Basingstoke, United Kingdom).

Three channels are used to measure dry $(\mathrm{RH}<25 \%)$ extinction coefficients at 405, 532, and $662 \mathrm{~nm}$. Two channels measure extinction coefficients downstream of $250{ }^{\circ} \mathrm{C}$ thermal denuder at 405 and $662 \mathrm{~nm}$, and two channels measure $532 \mathrm{~nm}$ extinction coefficients downstream of Nafion humidifiers (Permapure MH-110-12SD-4, Toms River, New Jersey, USA), which are controlled to 70 and $90 \% \mathrm{RH}$. An eighth channel measures $405 \mathrm{~nm}$ extinction coefficients downstream of a particle filter, which served as a check for the scrubbing 


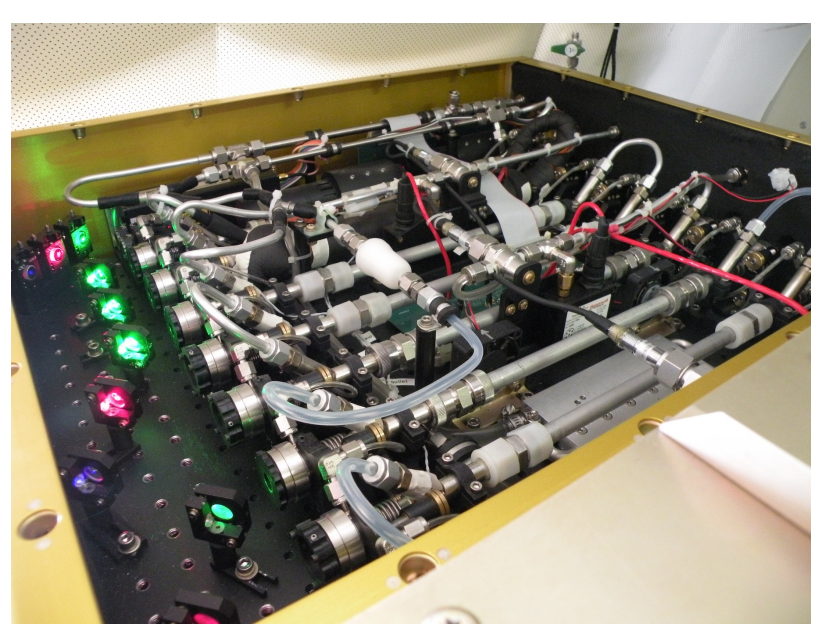

Figure A2. The eight separate ring-down cells in the CRD instrument.

of gas-phase absorbers. The CRD had a $1 \mathrm{~Hz}$ sensitivity of $0.1 \mathrm{Mm}^{-1}$, and accuracy of $<2 \%$, and a precision of $\sim 10 \%$ for extinctions in the range of $10-100 \mathrm{Mm}^{-1}$. The precision is improved to $\sim 1 \%$ with sample averaging to $60 \mathrm{~s}$.

\section{A3.2 Photoacoustic absorption spectrometer (PAS): PI Daniel Lack}

The PAS instrument (Lack et al., 2012) is composed of five separate acoustic resonators that also serve as sample cells that are each illuminated by a multi-pass optical cavity. A continuous-wave laser is intensity-modulated at the acoustic resonance frequency of each resonator. Light-absorbing particles heat the air, producing acoustic pulses that are detected with a sensitive microphone. Because the resonance frequency varies with pressure and temperature, a speaker is used to actively determine the resonance frequency and tune the laser modulation to match. Like the CRD instrument, the PAS samples aerosol downstream of a Nafion drier (Permapure PD-200T-12-MSS, Toms River, New Jersey, USA), and gas-phase absorbers are removed using an activated carbon monolith (MAST Carbon NovaCarb F, Basingstoke, UK).

Three of the channels of the PAS instrument are used to measure dry absorption coefficients at 405, 532 and $662 \mathrm{~nm}$. The remaining two channels measure absorption downstream of the thermal denuder. Accuracy of the PAS is $\sim 10 \%$ and sensitivity is $\sim 1 \mathrm{Mm}^{-1}$ for $1 \mathrm{~Hz}$ sampling.

The combined AOP instrument package measured the aerosol properties necessary for calculations of radiative forcing and atmospheric heating rates. Further, the measured parameters can be directly compared to those derived from remote sensing measurements from satellite, airborne, and ground-based sensors. Additional measurements, such as the change in aerosol absorption and extinction as condensed coatings are thermally evaporated from absorbing cores, will improve mechanistic understanding of the role of clear and brown carbon coatings in controlling aerosol optical properties, and the sources and evolution of these coatings in the atmosphere. Finally, the absorption of the refractory cores can be compared to the $\mathrm{BC}$ mass measurements, allowing a direct linkage between atmospheric loadings of $\mathrm{BC}$ and radiative effects and helping constrain simulations of aerosol impacts on climate.

\section{A4 Single-Particle Soot Photometer (SP2): PI Joshua P. Schwarz, Milos Markovic}

The SP2 is a laser-induced incandescence instrument that measures the refractory black carbon $(\mathrm{rBC})$ mass content of individual particles and thus delivers detailed information not only about rBC loadings, but also size distributions, even in exceptionally clean air (Schwarz et al., 2010). The instrument can also provide the optical size of individual particles containing $\mathrm{rBC}$ and identify the presence of optically significant internal mixtures with the BC fraction (Schwarz et al., 2008). Note that $\mathrm{rBC}$ is experimentally equivalent to elemental carbon as measured by OC / EC instruments at the level of $15 \%$ (Kondo et al., 2011).

The SP2 system is shown schematically in Fig. A3. Ambient air is drawn through an intense intracavity laser (a diode-pumped Nd:YAG laser operating in a Gaussian TEM00 mode at $1.064 \mu \mathrm{m}$ wavelength). Aerosol particles in the air enter the laser singly and scatter laser light according to their size, composition and morphology. The quantity of scattered light and its evolution in time are recorded. When an $\mathrm{rBC}-$ containing particle enters the laser, the $\mathrm{rBC}$ is heated to vaporization $(\sim 3500 \mathrm{~K})$, emitting blackbody radiation (incandescent light) in the visible in quantities directly related to its mass, regardless of particle morphology or mixing state. The color of this radiation is detected and used to deduce the vaporization temperature of the particle as a constraint on its composition. A detector system developed by NOAA is used to optically size rBC-containing particles before laser heating perturbs them. This allows quantification of the amount of non-BC material (interpreted as a coating thickness via shell-core Mie theory) associated with each BC core, and its impact on the optical properties (including absorption crosssection) of the BC-component. Only a limited range of $\mathrm{rBC}$ mass in individual particles can be quantified; this range covers most of the accumulation mode rBC mass that dominates total $\mathrm{rBC}$ aerosol loadings, except near tail-pipes.

\section{A5 Compact-Time-of-Flight Aerosol Mass Spectrometer (C-ToF AMS): PI Ann Middlebrook, Jin Liao, Andre Welti}

A key aspect of the SENEX project was to quantify the abundance and chemical composition of atmospheric aerosol particles above the southeastern United States. To accomplish this, we use a semi-custom Compact Time-of-Flight Aerosol 


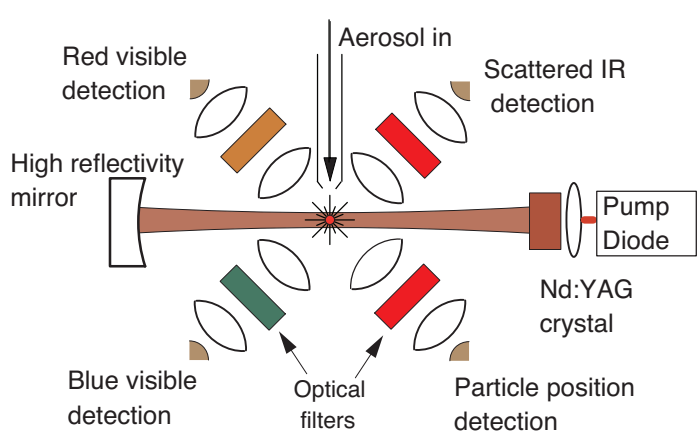

Figure A3. Schematic diagram of the SP2 photometer showing the basic optics and laser-induced incandescence and scattering detectors.

Mass Spectrometer or C-ToF-AMS with a light scattering (LS) module (Aerodyne Research Inc., Billerica, MA).

The general operation of AMS instruments has been described elsewhere (Allan et al., 2003; Canagaratna et al., 2007; Jayne et al., 2000; Jimenez et al., 2003). Briefly, particles are transmitted into the AMS detection region using an aerodynamic focusing lens, where they impact an invertedcone porous-tungsten vaporizer typically held at $\sim 600^{\circ} \mathrm{C}$, and volatilize, with the vapors being analyzed by electron ionization mass spectrometry. The C-ToF-AMS system deployed here employs a long aerosol time-of-flight drift region and a compact-time-of-flight mass spectrometer, which combined has high-size resolution and high sensitivity for individual particle mass spectral signals (DeCarlo et al., 2006; Drewnick et al., 2005). Particles between 100 and $700 \mathrm{~nm}$ vacuum aerodynamic diameter are sampled with $100 \%$ efficiency through the specific aerodynamic focusing lens used here and the custom pressure-controlled inlet designed for airborne operation (Bahreini et al., 2008; Liu et al., 1995). Details on calibration, data collection and data processing are described elsewhere (Allan et al., 2004; Bahreini et al., 2009; Middlebrook et al., 2012). For SENEX, the AMS was operated with low sensitivity, which increased the uncertainty in accuracy to roughly $50 \%$.

The LS module has been previously used by other investigators in a few laboratory and field studies (Cross et al., 2007, 2009; Liu et al., 2013; Slowik et al., 2010). Here it was deployed for the first time on an airborne platform. The LS module consists of a $405 \mathrm{~nm}$, continuous laser beam directed at the end of the aerosol time-of-flight drift region before particles impact on the vaporizer, an ellipsoidal mirror for collecting scattered light from particles passing through the laser beam, and a photomultiplier tube for detecting and measuring the scattered light. The data acquisition software used the scattered light signal to trigger saving mass spectra for that individual particle.

One important factor for particle detection efficiency in the AMS instrument is efficient evaporation after particle impaction on the vaporizer, where inefficient evaporation is commonly referred to as particle bounce (Matthew et al., 2008; Middlebrook et al., 2012). To provide a direct measurement of this factor for ambient aerosols, particles must be large enough to scatter light in the instrument (for the current system $\sim 100 \mathrm{~nm}$ in diameter), provide enough signal from the single particle mass spectra to detect them, and evaporate in less than a few hundred $\mu \mathrm{s}$. The LS module provides a quantitative measure of the particles that are not detected due to bouncing on the vaporizer.

\section{A6 Carbon dioxide $\left(\mathrm{CO}_{2}\right)$ and methane $\left(\mathrm{CH}_{4}\right)$ (Picarro): PI Jeff Peischl, Thomas Ryerson}

Measurements of the greenhouse gases carbon dioxide $\left(\mathrm{CO}_{2}\right)$ and methane $\left(\mathrm{CH}_{4}\right)$ were used to determine the sources and magnitudes of these emissions in the southeastern US during SENEX. $\mathrm{CO}_{2}$ and $\mathrm{CH}_{4}$ were measured aboard the WP-3D aircraft using a modified commercial wavelength-scanned cavity ring-down analyzer (Picarro 1301-m) (Peischl et al., 2012). Atmospheric air was sampled through a $3 / 8^{\prime \prime}$ OD stainless steel rearward facing inlet on the WP-3D and dried to a dew point temperature of $-78^{\circ} \mathrm{C}$ after passage through a 200-strand Nafion dryer and a dry ice trap. The absorption cell pressure was controlled at 140 Torr $( \pm 0.2$ Torr during smooth flight, and \pm 0.5 Torr during typical boundary layer flight conditions; all stated uncertainties are $\pm 1 \sigma$ ).

Immediately inside the fuselage, two $\mathrm{CO}_{2}$ and $\mathrm{CH}_{4}$ calibration gas standards were regularly added to the inlet line during flight to evaluate instrument sensitivity. The calibration standards bracketed the expected ambient range of each gas and are known to within $\pm 0.07 \mathrm{ppm} \mathrm{CO}_{2}$ and $\pm 1 \mathrm{ppb}$ $\mathrm{CH}_{4}$ (all $\mathrm{CO}_{2}$ and $\mathrm{CH}_{4}$ mixing ratios are reported as dry air mole fractions). The calibration gases were added at a flow rate sufficient to overflow the inlet. These flight standard tanks, or secondary standards, were calibrated before and after the field project using primary $\mathrm{CO}_{2} / \mathrm{CH}_{4}$ standard tanks tied to the WMO standard scale from the Global Monitoring Division (GMD) at the NOAA Earth System Research Laboratory (ESRL). A third calibration standard (referred to as a target) was regularly introduced to the inlet between calibrations and treated as an unknown to evaluate long-term instrument performance.

Independent of the target retrievals, we estimated a total accuracy in the $\mathrm{CO}_{2}$ measurement of $\pm 0.10 \mathrm{ppmv}$ and a total accuracy in the $\mathrm{CH}_{4}$ measurement of $\pm 1.2 \mathrm{ppbv}$ for $20 \mathrm{~s}$ averages. The 1-second precision of the $\mathrm{CO}_{2}$ measurement was \pm 0.10 ppmv during smooth flight and \pm 0.15 ppmv during turbulent flight. The 1-second precision of the $\mathrm{CH}_{4}$ measurement was $\pm 1.5 \mathrm{ppbv}$ during smooth flight and $\pm 2.0 \mathrm{ppbv}$ during turbulent flight. 


\section{A7 Carbon monoxide (CO) and sulfur dioxide $\left(\mathrm{SO}_{2}\right)$ : PI John Holloway}

The CO instrument was contained in a pod located on the left wing inboard (Holloway et al., 2000). The instrument consists of a VUV fluorimeter, a vacuum/sample pump, compressed gas cylinders, and a data system and computer. The computer in the wing pod boots when electrical power is supplied to the pod. Data acquisition software starts automatically. Communication with the pod is by means of 100BASE-T Ethernet. The precision of the measurements is estimated to be $2.5 \%$. Variability in the determination of zero levels results in an absolute uncertainty of about $0.5 \mathrm{ppbv}$ in the values reported. The field standard was compared to NIST Standard Reference Material (SRM) 2612a (10 ppmv nominal $\mathrm{CO}$ in air). The concentration of the calibration standard is known to within $2 \%$. The overall accuracy of the $1 \mathrm{~s}$ measurements is thus estimated to be $5 \%$.

The $\mathrm{SO}_{2}$ instrument was located in a one bay rack inside the aircraft. It consists of a TECO model 43C pulsed fluorimeter, an external sample pump, a rack mounted computer and associated data system interface box, compressed gas cylinders containing zero air and a $10 \mathrm{ppm} \mathrm{SO}_{2} / \mathrm{N}_{2}$ calibration standard, and a calibration system mounted on the sample inlet (Ryerson et al., 1998).

\section{A8 Nitrogen oxides and ozone $\left(\mathrm{NO}_{y} / \mathrm{O}_{3}\right)$ : PI Ilana Pollack, Thomas Ryerson}

The NOAA $\mathrm{NO}_{y} \mathrm{O}_{3}$ four-channel chemiluminescence (CL) instrument provided in situ measurements of nitric oxide (NO), nitrogen dioxide $\left(\mathrm{NO}_{2}\right)$, total reactive nitrogen oxides $\left(\mathrm{NO}_{y}\right)$, and ozone $\left(\mathrm{O}_{3}\right)$ on the WP-3D during SENEX. This instrument has flown on the WP-3D, the NCAR Electra, and the NASA DC-8 research aircraft on multiple field projects since 1995 (Pollack et al., 2010; Ryerson et al., 1999, 2000). It provides fast-response, chemically specific, high precision, and calibrated measurements of nitrogen oxides and ozone at a spatial resolution of better than $50 \mathrm{~m}$ at typical WP-3D research flight speeds.

Detection is based on the gas-phase CL reaction of NO with $\mathrm{O}_{3}$ at low pressure, resulting in photoemission from electronically excited $\mathrm{NO}_{2}$. Photons are detected and quantified using pulse counting techniques, providing $\sim 5$ to 10 part-per-trillion by volume (pptv) precision at $1 \mathrm{~Hz}$ data rates.

One CL channel is used to measure ambient NO directly, a second channel is equipped with a high-power UV-LED converter to photodissociate ambient $\mathrm{NO}_{2}$ to $\mathrm{NO}$, and a third channel is equipped with a heated gold catalyst to reduce ambient $\mathrm{NO}_{y}$ species to NO. Reagent ozone is added to these sample streams to drive the CL reactions with NO. Ambient $\mathrm{O}_{3}$ is detected in the fourth channel by adding reagent NO.

Instrument performance is routinely evaluated in flight by standard addition calibrations delivered within a few cen- timeters of the inlet tips. The separate $\mathrm{NO}$ and $\mathrm{NO}_{2}$ sample paths, detectors, and inlet residence times are identical, permitting artifact-free calculation of ambient $\mathrm{NO}_{2}$ by difference at high time resolution, with no lagging or smoothing relative to $\mathrm{NO}$ or to other fast-response measurements aboard the aircraft. A high-power UV-LED converter developed in our laboratory provides $\mathrm{NO}_{2}$ conversion fractions exceeding 0.6 at a converter sample residence time of $0.11 \mathrm{~s}$. This offers a significant advantage in terms of $\mathrm{NO}$ and $\mathrm{NO}_{2}$ spatial resolution compared to other airborne $\mathrm{NO}_{2}$ instruments. The $\mathrm{NO}_{y}$ channel is calibrated to $\mathrm{NO}, \mathrm{NO}_{2}$, and $\mathrm{HNO}_{3}$ in flight and the $\mathrm{O}_{3}$ channel is calibrated over an atmospherically relevant range of ozone mixing ratios in flight.

\section{A9 Proton transfer reaction mass spectrometer (PTR-MS): PI Martin Graus, Carsten Warneke}

Proton transfer reaction mass spectrometry (PTR-MS) (de Gouw et al., 2003; de Gouw and Warneke, 2007; Warneke et al., 2011b) allows for real-time measurements of volatile organic compounds (VOCs) in air with a high sensitivity and a fast time response. In PTR-MS, proton-transfer reactions with $\mathrm{H}_{3} \mathrm{O}^{+}$ions are used to ionize VOCs in air: $\mathrm{H}_{3} \mathrm{O}^{+}+\mathrm{VOC} \rightarrow$ VOC $\cdot \mathrm{H}^{+}+\mathrm{H}_{2} \mathrm{O}$.

The air to be analyzed is continuously pumped through a drift tube reactor, where the VOCs are ionized in the protontransfer reactions with $\mathrm{H}_{3} \mathrm{O}^{+}$, produced in the hollowcathode discharge ion source (Fig. A4). $\mathrm{H}_{3} \mathrm{O}^{+}$and product ions are detected with a quadrupole mass spectrometer. The inlet, shown in Fig. A4, is pressure and temperature controlled and consists of PEEK and Teflon tubing and valves. Diverting the air through a catalytic converter that burns the VOCs periodically zeros the instrument. In between flights, sensitivity calibrations are performed using dynamically diluted VOC standards.

VOCs with a higher proton affinity than water can be detected by PTR-MS and usually reported are: methanol, acetonitrile, acetaldehyde, acetone, isoprene, sum of methyl vinyl ketone and methacrolein, methyl ethyl ketone, benzene, toluene, sum of C8-aromatics, sum of C9-aromatics, and sum of monoterpenes.

The PTR-MS has a response time of about $1 \mathrm{~s}$ and all compounds are measured for $1 \mathrm{~s}$ every $17 \mathrm{~s}$ at detection limits of 30-200 pptv and an uncertainty of 20-30\% dependent on the VOC. The PTR-MS was set-up for SENEX nearly identical to what was used in many previous NOAA airborne field campaigns such as CALNEX 2010 and ARCPAC 2008.

\section{A10 Whole air sampler with immediate GC-MS analysis (iWAS/GCMS): PI Jessica Gilman, Brian Lerner}

The iWAS/GCMS is designed to speciate and quantify a variety of VOCs including alkanes, alkenes, biogenic VOCs (BVOCs), oxygenated VOCs (OVOCs), VOCs containing 

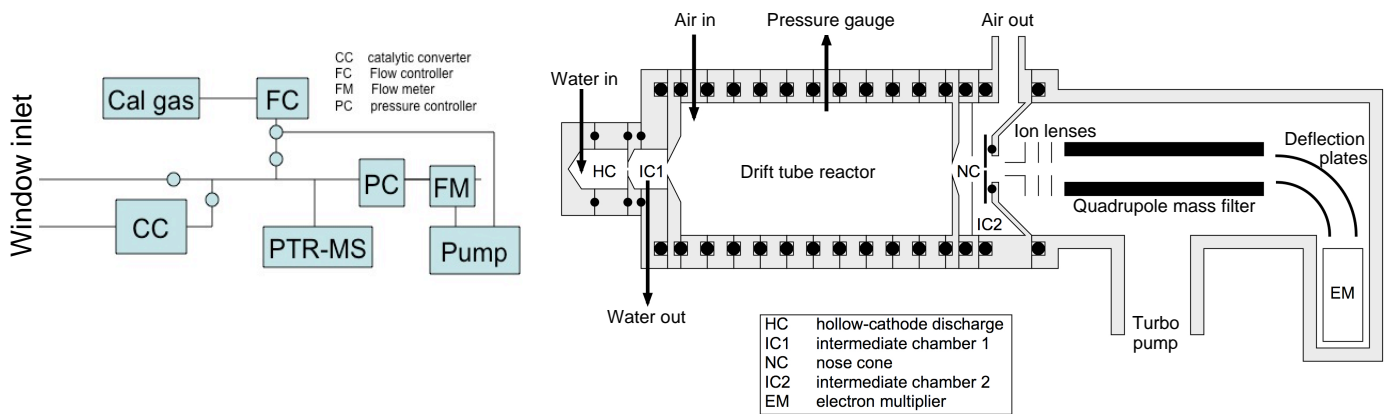

Figure A4. Schematic drawing of the PTR-MS instrument and the inlet.

nitrogen, and halogenated VOCs in discrete air samples. iWAS/GCMS consists of 3 independent components: (1) onboard in situ sample collection via 72 whole air sample (WAS) canisters, consisting of six 12-canister modules, located in AMPS pod on WP-3D, (2) in-field analysis of WAS canisters via gas chromatography-mass spectrometry (GCMS), and (3) cleaning and conditioning of canisters for reuse on subsequent research flights. The canister design, collection, and conditioning protocols have been adopted from the NCAR AWAS system (Schauffler et al., 2003).

A detailed description of iWAS/GC-MS will be presented by Lerner et al. (2016). The onboard sampling system consists of a 316 SS forward-facing inlet, a stainless steel bellows compressor (Senior Aerospace), a sampling manifold, and 72 electro-polished stainless steel canisters $(1.4 \mathrm{~L})$. Each canister is isolated from the sample manifold by a stainless steel bellows valve actuated by a computer-controlled pneumatic valve system. The canisters may be automatically filled at regular time intervals during aerial surveys or triggered manually for targeted plume analysis. During sample collection, each canister is pressurized to approximately 50 psia by the compressor. Total sample acquisition time is typically $3-$ $10 \mathrm{~s}$ depending upon ambient air pressure, which varies with aircraft altitude.

Post-flight, the canister modules are removed from the AMPS pod and connected to the analysis system via $1 / 8^{\prime \prime}$ silanized stainless steel tubing. The sample manifold is pumped out for approximately $2 \mathrm{~h}$ to remove any residual water, then flushed with UHP nitrogen and evacuated before an individual canister is opened for analysis. This sequence of flushing and pumping is repeated before each canister is sampled.

Each canister is analyzed via gas chromatography-mass spectrometry (GC-MS). The custom-built GC-MS consists of two channels optimized for light VOCs (channel 1, C2C6 compounds) and heavier VOCs (channel 2, C5-C11 compounds). Two $240 \mathrm{sccm}$ samples are simultaneously collected from each canister. Prior to sample trapping, $\mathrm{H}_{2} \mathrm{O}$ is removed from the sample stream via a cold trap (nominally -45 and $-35^{\circ} \mathrm{C}$, respectively), and $\mathrm{CO}_{2}$ is removed from the channel 1 sample via an ascarite scrubber. VOCs are pre- concentrated via cryogenic trapping at temperatures of -165 and $-145^{\circ} \mathrm{C}$ for channels 1 and 2 , respectively. The samples are analyzed sequentially with a porous layer open tubular (PLOT) $\mathrm{Al}_{2} \mathrm{O}_{3}$ column and a mid-polarity polysiloxane column for channels 1 and 2, respectively, with the analyte from both columns sent to a single quadrupole mass spectrometer detector run in selective ion mode for increased signalto-noise. The entire sample pre-concentration $(4 \mathrm{~min})$ and separation/analysis/flush (16 $\mathrm{min}$ ) is automatically repeated for subsequent canisters. All 72 canisters collected per flight were analyzed on-site between $12-100 \mathrm{~h}$ after the aircraft had landed.

The GC-MS provides chemically detailed and highly sensitive measurements with detection limits in the 2-10 pptv range depending on the VOC. Each VOC is identified by its chromatographic retention time and electron-impact mass fragmentation pattern. All VOCs are individually calibrated using commercial and custom-made calibration standards. For SENEX, approximately 20 VOCs were quantified for each canister sample. A detailed description of the iWAS2 will presented by Lerner et al. (2016).

After the canisters are analyzed, they are prepared and conditioned for reuse. Each canister is evacuated $(<10$ mTorr) and checked for leaks. The canisters are then heated to $75^{\circ} \mathrm{C}$ under vacuum, then filled with high-purity nitrogen and re-evacuated. The nitrogen flush process is repeated a minimum of three times. Humidified nitrogen is added during the final flushing process in order to passivate the interior surfaces of the canisters.

\section{A11 Nitric acid $\left(\mathrm{HNO}_{3}\right)$, formic acid $(\mathrm{HCOOH})$, and HONO: PI Andy Neuman}

$\mathrm{HNO}_{3}, \mathrm{HCOOH}$, and $\mathrm{HONO}$ were measured by chemical ionization mass spectrometry (CIMS) using $\mathrm{I}^{-}$as a reagent ion (Neuman, 2015). The instrument included a heated inlet to deliver ambient air to the instrument, a flow tube where ions and ambient air reacted, and a quadrupole mass spectrometer for ion detection.

The $70 \mathrm{~cm}$ long inlet was housed in an aerodynamic winglet that was perpendicular to the aircraft fuselage. The 
inlet was temperature controlled to $40^{\circ} \mathrm{C}$, and the total airflow through the inlet was 8 standard $\mathrm{L} \mathrm{min}^{-1}$ (Neuman et al., 2002). An all-Teflon valve located at the inlet tip was used to determine the instrument background signal. Every $30 \mathrm{~min}$, the valve was actuated so that air was sampled for $1.5 \mathrm{~min}$ through a charcoal filter that removed $\mathrm{HNO}_{3}, \mathrm{HCOOH}$, and HONO from the air stream. The signal during these background measurements came from the instrument and was subtracted from the total signal to determine ambient mixing ratios. The inlet also included a port at the tip where calibration gas was added. $\mathrm{HNO}_{3}$ and $\mathrm{HCOOH}$ at ppbv-levels were added to the inlet tip in-flight for 2 min approximately every hour. The $\mathrm{HNO}_{3}$ and $\mathrm{HCOOH}$ sources were calibrated using permeation tubes. After each flight, the permeation tubes were removed from the aircraft and kept under constant flow and temperature, and the output from the $\mathrm{HNO}_{3}$ calibration source was measured by UV optical absorption (Neuman et al., 2003). Mixing ratios were determined from these standard addition calibrations. The instrument was calibrated to HONO in the laboratory prior to the study, using HONO produced from the reaction of $\mathrm{HCl}$ with humidified $\mathrm{NaNO}_{3}$ (Roberts et al., 2010).

Ambient air from the inlet was mixed with ions in a reduced pressure flow tube. Approximately 1.6 standard $\mathrm{L} \mathrm{min}^{-1}$ of the total 8 standard $\mathrm{L} \mathrm{min}^{-1}$ inlet flow was admitted through an orifice into a flow tube at 20 Torr and $20^{\circ} \mathrm{C}$. The reagent ions were made in flight by flowing 2 standard $\mathrm{L} \min ^{-1} \mathrm{~N}_{2}$ doped with methyl iodide through a radioactive $210 \mathrm{Po}$ ion source. This ions and ambient air reacted for approximately $200 \mathrm{~ms}$ in the flow tube. Since $\mathrm{HNO}_{3}$ and $\mathrm{HCOOH}$ are more sensitive to water clustered with $\mathrm{I}^{-}$, water was added to the flow tube to prevent large changes in sensitivity with ambient water (Neuman et al., 2010; Zheng et al., 2011).

The quadrupole mass spectrometer was programmed to integrate signals from each of the product and reagent ions for a fraction of a second, in a sequence that repeated every second. As a result, an independent measurement for each compound was obtained once per second. Several times per flight the mass spectrometer was programmed to scan over the entire mass range (10 to $250 \mathrm{amu}$ ) as a diagnostic of the ion chemistry stability. During instrument calibrations, zeroes, and mass scans, ambient measurements were not reported.

Measurement accuracy was determined from the variability of the instrument response to in-flight calibrations and from the uncertainty in the emission from the calibration sources. $\mathrm{HNO}_{3}$ was measured with $25 \mathrm{pptv}$ precision (for $1 \mathrm{~s}$ data) and an accuracy of $\pm(20 \%+50 \mathrm{pptv})$. $\mathrm{HCOOH}$ was measured with $40 \mathrm{pptv}$ precision (for $1 \mathrm{~s}$ data) and an accuracy of $\pm(20 \%+120 \mathrm{pptv})$. HONO was measured with $25 \mathrm{pptv}$ precision (for $1 \mathrm{~s}$ data) and an accuracy of $\pm(40 \%+30 \mathrm{pptv})$. The two accuracy terms represent uncertainties in the in-flight calibrations (\%) and instrumental background measurements (pptv).

\section{A12 Ammonia ( $\left.\mathrm{NH}_{3}\right)$ : PI John Nowak}

Gas-phase $\mathrm{NH}_{3}$ was measured during SENEX with a CIMS utilizing protonated acetone dimer $\left(\left(\mathrm{C}_{3} \mathrm{H}_{6} \mathrm{O}\right) \mathrm{H}^{+}\left(\mathrm{C}_{3} \mathrm{H}_{6} \mathrm{O}\right)\right)$ ion chemistry as described by Nowak et al. (2007). Previously, this instrument was successfully deployed aboard the WP-3D during the 2004 New England Air Quality Study (NEAQS) (Nowak et al., 2007), the 2006 Texas Air Quality Study (TexAQS 2006) (Nowak et al., 2010), and the 2010 CalNex study (Nowak et al., 2012). The inlet, low-pressure flow tube reactor, and quadrupole mass spectrometer are similar to the airborne $\mathrm{HNO}_{3}$-CIMS described above.

In-flight standard addition calibrations and measurements of instrumental background signals were routinely performed to determine the sensitivity, stability, and time response of the instrument. Standard addition calibrations with $13 \mathrm{ppb}$ of $\mathrm{NH}_{3}$ were performed 3-5 times a flight with the output of a thermostated, flow-controlled, pressurized $\mathrm{NH}_{3}$ permeation device (Kin-tek, La Marque, TX). The stability of the permeation device output was maintained between flights by removing the permeation oven from the aircraft and connecting it to a ground support system where the same flow and temperature conditions were maintained. The output of the $\mathrm{NH}_{3}$ permeation device was quantified by UV absorption at $184.95 \mathrm{~nm}$ on the ground between each flight (Neuman et al., 2003) and varied less than $10 \%$ over the duration of the study. In-flight instrument sensitivity to $\mathrm{NH}_{3}$ was 1 ion counts s${ }^{-1} \mathrm{ppt}^{-1}\left(\mathrm{~Hz} \mathrm{ppt}^{-1}\right)$ for $1 \times 10^{6} \mathrm{~Hz}$ of reagent ion signal as determined by the flow conditions.

The instrument background was determined in-flight by periodically pulling ambient air through a scrubber filled with commercially available silicon phosphates (Perma Pure, Inc). For most flights, the absolute background level ranged from 0.1 to $0.4 \mathrm{ppb}$. However, due to reduced flow conditions, on the $11,12,16$, and 18 June flights, the observed absolute background levels were higher, ranging from 1.8 to $2.1 \mathrm{ppb}$. During most flights, the difference between consecutive backgrounds was 0.02 to $0.07 \mathrm{ppb}$. Again, for the flights of $11,12,16$, and 18 June, the difference between consecutive backgrounds was larger, ranging from 0.3 to $0.5 \mathrm{ppb}$. The instrument background signal is determined by interpolating between consecutive background measurements. Ambient mixing ratios were derived by subtracting the instrument background from the total signal. Typically, the overall $1 \sigma$ uncertainty for the $\mathrm{NH}_{3}$ measurement was estimated to be $\pm(25 \%+0.07 \mathrm{ppb})+0.02 \mathrm{ppbv}$ for a $1 \mathrm{~s}$ measurement with larger estimates for the $11,12,16$, and 18 June flights.

The instrument time response to ambient variability was determined from the $\mathrm{NH}_{3}$ signal decay following the removal of the calibration gas. These data were fitted with exponential decay curves, as described by Nowak et al. (2007). On average the 2 e-folding signal decay time from a triple exponential fit ranged from 1 to $2 \mathrm{~s}$ with typically at least $80 \%$ of the signal decay occurring within $1 \mathrm{~s}$. Therefore, $1 \mathrm{~s}$ was used as the observed instrument time response during SENEX 2013 
and in the data archive. $1 \mathrm{~s}$ instrument time response corresponds to a spatial resolution of $\sim 100 \mathrm{~m}$ at typical WP-3D research flight speeds.

\section{A13 PAN: PI Jim Roberts, Patrick Veres}

Acyl peroxynitrates, (PANs), and nitryl chloride $\left(\mathrm{ClNO}_{2}\right)$ were measured onboard the WP-3D during SENEX using a thermal-decomposition chemical ionization mass spectrometer similar to the instrument originally described by Slusher et al. (2004). The detection principle of PANs is thermal decomposition at $150^{\circ} \mathrm{C}$ followed by reaction of the resulting acyl peroxy radicals with iodide and iodide water cluster ions $\left.\left(\mathrm{I}^{-}+\mathrm{I} \mathrm{H}_{2} \mathrm{O}\right]^{-}\right)$in an ion flow tube to produce a stable carboxylate $\left[\mathrm{RC}(\mathrm{O}) \mathrm{O}^{-}\right]$ion. The carboxylate ions are then measured with a quadrupole mass spectrometer. Nitryl chloride was detected as either $\mathrm{ICl}^{-}$or $\mathrm{IClNO}_{2}^{-}$after reaction with $\mathrm{I}^{-}+\mathrm{I}\left[\mathrm{H}_{2} \mathrm{O}\right]^{-}$.

The instrument flow configuration used for PANs was based on that described by Slusher et al. (2004) with some modifications. Ambient air was sampled from outside the aircraft through a $6.3 \mathrm{~mm}$ OD PFA tube, temperature controlled at $30^{\circ} \mathrm{C}$, inside a small winglet that extended approximately $37 \mathrm{~cm}$ from the skin of the aircraft. The airflow was then directed to the inlet system of the instrument through a $9 \mathrm{~mm}$ OD PFA tube at cabin temperature. The inlet system consisted of a pair of PFA valves, configured such that the air flow can be periodically directed through a zeroing loop consisting of a $1.5 \mathrm{~m}$ length of $6.3 \mathrm{~mm}$ OD stainless steel tube held at $225^{\circ} \mathrm{C}$, sufficient to thermally decompose essentially all the PAN compounds in the sample stream, and approximately $95 \%$ of $\mathrm{ClNO}_{2}$. A small flow of ${ }^{13} \mathrm{C}$-labeled PAN was added through a normally open port of a 3-way valve (Zheng et al., 2011). The valve permitted the labeled standard to be switched out of line periodically to determine instrument backgrounds, and to check for cross-sensitivities at other masses due to proton transfer chemistry involving acetate ions (Veres et al., 2008). The airflow then passed through a pressure reduction pinhole into a heated zone consisting of $25 \mathrm{~cm}$ long section of $9 \mathrm{~mm}$ OD FEP tubing held at $150^{\circ} \mathrm{C}$. The exit of this tube was connected to the ion flow tube via another stainless steel pinhole. The ion flow tube was operated at a pressure of 25 Torr, controlled by bleeding cabin air into the pump line with a pressure controller (MKS 640). Ions were introduced into the flow tube by passing 2 standard $\mathrm{L} \mathrm{min}^{-1}$ of 3 ppmv methyl iodide through a ${ }^{210} \mathrm{Po}$ ionizer. A small flow of $\mathrm{N}_{2}$ saturated with water was added to the front of the ion flow tube, in order to keep the flow tube humidity above the thresholds at which the ion chemistry is dominated by $\left.\mathrm{I}^{\mathrm{H}} \mathrm{H}_{2} \mathrm{O}\right]^{-}$clusters (Kercher et al., 2009; Mielke et al., 2011; Slusher et al., 2004; Zheng et al., 2011).

The instrument was operated in selected ion mode switching among 10 ions in succession, every $2 \mathrm{~s}$, dwelling on each one for $0.1 \mathrm{~s}$ in the case of $\mathrm{I}^{-}$and $0.2 \mathrm{~s}$ for the other 9 . The inlet operation sequence provided a zero lasting $30 \mathrm{~s}$ every $10 \mathrm{~min}$. In addition, the labeled standard was turned off for $30 \mathrm{~s}$ every $10 \mathrm{~min}, 5 \mathrm{~min}$ apart from the zeros.

On-line calibration of the instrument for PANs was accomplished through the constant addition of ${ }^{13} \mathrm{C}_{2}$-labelled PAN that is produced in a pressure-controlled photosource similar to that described by Zheng et al. (2011). PAN was produced with an efficiency of $93 \pm 5 \%$ from a nitric oxide standard as determined from measurements of $\mathrm{NO}_{x}$ and $\mathrm{NO}_{y}$ using the CRDS instrument. The other PAN compounds were calibrated relative to this photosource before and after the project with the methods described by Veres and Roberts (2015). Nitryl chloride was calibrated using a portable source that uses the reaction of molecular chlorine $\left(\mathrm{Cl}_{2}\right)$ with sodium nitrite $\left(\mathrm{NaNO}_{2}\right)$ as described by Thaler et al. (2011) with a the output of the source calibrated by thermal decomposition at $350^{\circ} \mathrm{C}$ and detection by $\mathrm{NO}_{2}$ using CRDS as described by Wild et al. (2014).

The propagated uncertainties in the ${ }^{13} \mathrm{C}$ PAN calibration, flows, and instrument zero determinations result in an overall accuracy for PAN measurements of $\pm(15 \%+5 \mathrm{pptv})$, and $\pm(20 \%+5 \mathrm{pptv})$ for the other PAN species. The uncertainty of $\mathrm{ClNO}_{2}$, measured at the ICl- mass was $\pm(30 \%+25 \mathrm{pptv})$. Roiger et al. (2011) have pointed out that the use of a ${ }^{13} \mathrm{C}$ PAN standard for measuring native PAN at mass 59 requires a correction for the natural abundance of heavy isotopes. Since the ${ }^{13} \mathrm{C}$ labeled acetone used for the photosource is rated at $99 \%$ purity per carbon, the corresponding correction for our PAN standard would be about $3 \%$ and we chose not to correct our ambient PAN for heavy isotopes. Phillips et al. (2013) have observed peroxyacetic acid conversion to acetate in their PAN CIMS. Several tests before and during SENEX were performed to explore whether our PAN CIMS had similar sensitivity. Cold inlet (i.e., no thermal decomposition), $\mathrm{NO}$ addition to titrate $\mathrm{CH}_{3} \mathrm{C}(\mathrm{O}) \mathrm{OO}$ radicals and possible signal modulation at carboxylate masses when the ${ }^{13} \mathrm{C}$ PAN standard is switched out all indicated no significant signals due to peroxyacids.

\section{A14 Multifunctional organic molecules and inorganics by I ${ }^{-}$CIMS: PI Joel A. Thornton, Felipe D. Lopez-Hilfiker, Ben H. Lee}

The instrument used consisted of a reduced-pressure ionmolecule reaction (IMR) region, coupled to an atmospheric pressure interface HR-ToF-MS (Tofwerk AG, Thun, Switzerland) (Lee et al., 2014).

Ambient air is drawn through a critical orifice at 2.0 standard $\mathrm{L} \mathrm{min}^{-1}$ into the IMR, which is held at $90 \mathrm{mbar}$ by means of a scroll pump (Agilent IDP3) and a custom servo-controlled vacuum valve used to continuously regulate pumping speed. The pressure varies by $<1 \%$ even as ambient pressure changes by factors of 5 . The IMR temperature is controlled to within $0.2^{\circ} \mathrm{C}$ at a set point between ambient and $40^{\circ} \mathrm{C}$ depending upon application. Up to two com- 
mercial radioactive ion sources (Po-210, $10 \mathrm{mCi}, \mathrm{NRD}$ ) oriented $90^{\circ}$ apart and orthogonal to the ion-molecule reaction mixture flow can be used for switching between positive and negative reagent ions. The IMR also contains a diffusion cell to continuously deliver calibration compounds for converting measured ion flight times into $m / Q$.

Iodide ions are generated by passing a 2 standard $\mathrm{L} \mathrm{min}^{-1}$ flow of ultrahigh purity (UHP) $\mathrm{N}_{2}$ over a permeation tube filled with methyl iodide and then through the Po-210 ion source into the IMR. The ionizer and sample flows mix and interact for $\sim 120 \mathrm{~ms}$ until a fraction is sampled through an orifice into a four-stage differentially pumped chamber housing the HR-ToF-MS. The first stage is held at 2 mbar by a molecular drag pump (Alcatel MDP 5011), and the second stage is held at 0.01 mbar by a split-flow turbo molecular pump (Pfeiffer). Two quadrupole ion guides transmit the ions through these two stages while providing collisional cooling and thus energetic homogenization of the ions as they enter the third extractor region. In the third and final stages, additional optics further focus the ions prior to being orthogonally pulsed at $22.22 \mathrm{kHz}$ into the drift region where their arrival time after a V-mode trajectory is detected with a pair of microchannel plate detectors (Photonis Inc., USA).

Minimizing sampling losses of low volatility species is a priority. Ambient air is drawn at 22 standard $\mathrm{L} \mathrm{min}^{-1}$ through a $72 \mathrm{~cm}$ long $1.6 \mathrm{~cm}$ inner diameter polytetrafluoroethylene (PTFE) tubing by a dedicated scroll pump (Agilent IDP3). The first $25 \mathrm{~cm}$ of the inlet tube is housed in an aerodynamic winglet that extends outside of the boundary layer of the WP-3D aircraft. We estimate an inlet residence time of approximately $0.4 \mathrm{~s}$ at $1013 \mathrm{hPa}$ while maintaining laminar flow $(\operatorname{Re} \sim 1900)$. A small fraction of the centerline flow ( 2 standard $\mathrm{L} \mathrm{min}^{-1}$ ) is sampled through a conical-shaped critical orifice into the IMR, while the remainder is exhausted through four radially symmetric ports located downstream and around the raised sampling orifice. The inlet is heated to $40^{\circ} \mathrm{C}$ to minimize condensation on the tubing surface and to maintain a constant sampling environment under rapidly evolving outside and cabin conditions.

The instrument background signal is established by introducing dry UHP $\mathrm{N}_{2}$ directly in front of the critical orifice every $15 \mathrm{~min}$ to displace the incoming ambient air during flight. This addition is achieved by a servo-controlled, $7 \mathrm{~cm}$ long $0.3 \mathrm{~cm}$ diameter stainless steel probe that when actuated, enters from the side of the inlet at a $45^{\circ}$ angle and is positioned directly upstream of, but not in contact with, the sampling cone. Ambient air is rejected from the IMR by overblowing the sampling orifice with $\mathrm{N}_{2}\left(\sim 3\right.$ standard $\left.\mathrm{L} \min ^{-1}\right)$. When not in use, the probe is retracted so that it resides outside of the sample streamline. Instrument sensitivity dependence on water vapor pressure is accounted for, but given that the sensitivity for most organic compounds is higher in dry air, the measured background is more than likely an upper limit.

The stability of the instrument is determined by continuously delivering ${ }^{13} \mathrm{C}$-labeled formic acid, ${ }^{13} \mathrm{CH}_{2} \mathrm{O}_{2}$, through a 30 gauge $1.5 \mathrm{~cm}$-long needle bored through the PTFE inlet near the inlet entrance. The ${ }^{13} \mathrm{CH}_{2} \mathrm{O}_{2}$ (Cambridge Isotopes) was contained in a custom-built PTFE permeation tube, held at constant temperature $\left(40^{\circ} \mathrm{C}\right)$ and pressure. The permeation rate was determined gravimetrically and compared to independently verified ${ }^{12} \mathrm{CH}_{2} \mathrm{O}_{2}$ permeation tubes (KIN-TEK). Any drift in the instrument sensitivity measured by the $\left.\mathrm{I}^{13} \mathrm{CH}_{2} \mathrm{O}_{2}\right)^{-}$ion signal, not due to ambient water vapor, is similarly applied to all other species using relative sensitivities which have been determined in the laboratory.

\section{A15 Cavity enhanced absorption spectroscopy for glyoxal (ACES): PI Kyung-Eun Min, Rebecca Washenfelder, Steve Brown}

Glyoxal is one of the key reactive intermediates in the atmospheric oxidation of hydrocarbons, particularly biogenic VOCs and aromatic compounds (Fu et al., 2008). It is the simplest $\alpha$-dicarbonyl species, and it can serve either as a source of radicals through its photolysis or as a source of secondary organic aerosol through its heterogeneous uptake and subsequent oligomerization. It also has strong visible absorption bands that facilitate its detection via spectroscopic methods. Cavity enhanced spectroscopy, CES, is a recently developed technique for high-sensitivity, spectrally resolved measurements (Fiedler et al., 2003). As shown in Fig. A5, it employs a broadband light source, such as a light emitting diode (LED), an optical cavity and a grating spectrometer. The technique can achieve optical path lengths of several tens of kilometers for measurements of atmospheric trace gases at sub part per billion levels.

The CES technique has been demonstrated for measurement of glyoxal in both the laboratory (Washenfelder et al., 2008) and in the field during CalNex 2010 (Washenfelder et al., 2011b; Young et al., 2012). Ground based CES measurements during the CalNex 2010 campaign also included $\mathrm{NO}_{2}$ and HONO (Young et al., 2012).

For SENEX, a new aircraft version of the instrument achieved robust performance using a custom optical mounting system, high-power LEDs with electronic on/off modulation, state-of-the-art cavity mirrors, and materials that minimize analyte surface losses (Min et al., 2016). The aircraft instrument is called the Airborne Cavity Enhanced Spectrometer (ACES). The ACES instrument has two channels with wavelength coverage from 361-389 and 438-468 nm. The wavelength range is determined by the LED spectral radiance, the center wavelength and bandwidth of the cavity mirrors, as well as the wavelength-dependent absorption features of target gases. HONO and $\mathrm{NO}_{2}$ are detected at 361$389 \mathrm{~nm}$, while $\mathrm{CHOCHO}, \mathrm{CH}_{3} \mathrm{COCHO}, \mathrm{NO}_{2}$, and $\mathrm{H}_{2} \mathrm{O}$ are detected at $438-468 \mathrm{~nm}$. The demonstrated precision $(2 \sigma)$ for retrievals of $\mathrm{CHOCHO}, \mathrm{HONO}$ and $\mathrm{NO}_{2}$ are 34,350 and $80 \mathrm{pptv}$ in $5 \mathrm{~s}$ (Min et al., 2016). The accuracy is 5.8, 9.0 and $5.0 \%$, limited mainly by the available absorption cross section (Min et al., 2016). 


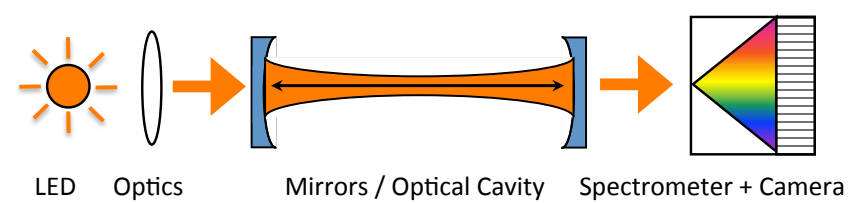

Figure A5. Simplified schematic of the broadband CES instrument.

\section{A16 Cavity ring-down spectroscopy (CRDS): PI Peter Edwards, Steve Brown}

Cavity ring-down spectroscopy (CRDS) is a high sensitivity optical technique for the measurement of trace gas concentration applicable to nitrogen oxides. The NOAA CRDS instrument for nitrogen oxides and ozone is based on two visible diode lasers at $662 \mathrm{~nm}$ (for detection of $\mathrm{NO}_{3}$ ) and $405 \mathrm{~nm}$ (for detection of $\mathrm{NO}_{2}$ ) (Wagner et al., 2011). Inlet conversions allow the measurement of additional species. Figure A6 shows a schematic of the instrument.

One $662 \mathrm{~nm}$ channel provides a direct measurement of $\mathrm{NO}_{3}$, while a second $662 \mathrm{~nm}$ channel with a heated inlet provides a measurement of the sum of $\mathrm{NO}_{3}$ and $\mathrm{N}_{2} \mathrm{O}_{5}$ via thermal dissociation of $\mathrm{N}_{2} \mathrm{O}_{5}$ to $\mathrm{NO}_{3}$. Both channels are zeroed by addition of $\mathrm{NO}$ to the inlet, which reacts rapidly with $\mathrm{NO}_{3}$, but not with other species that absorb $662 \mathrm{~nm}$ light, such as ambient $\mathrm{NO}_{2}, \mathrm{O}_{3}$ or water vapor (Dubé et al., 2006). The $\mathrm{NO}_{2}$ produced in this reaction has an absorption cross section nearly $10^{4}$ times smaller than $\mathrm{NO}_{3}$ and therefore does not interfere with the $\mathrm{NO}_{3}$ measurement.

There are three channels at $405 \mathrm{~nm}$. The first detects $\mathrm{NO}_{2}$ directly by total optical extinction at this wavelength, which is specific to $\mathrm{NO}_{2}$. The second channel has an addition of excess $\mathrm{O}_{3}$ to convert $\mathrm{NO}$ to $\mathrm{NO}_{2}$ to measure total $\mathrm{NO}_{x}$ $\left(=\mathrm{NO}+\mathrm{NO}_{2}\right)$ via Reaction (R1) (Fuchs et al., 2009).

$\mathrm{NO}+\mathrm{O}_{3} \rightarrow \mathrm{NO}_{2}+\mathrm{O}_{2}$

A third $405 \mathrm{~nm}$ channel has an addition of excess NO to quantitatively convert $\mathrm{O}_{3}$ to $\mathrm{NO}_{2}$ to measure total $\mathrm{O}_{x}$ $\left(=\mathrm{O}_{3}+\mathrm{NO}_{2}\right)$, also via Reaction (AR1) (Washenfelder et al., 2011a). Differencing between the $\mathrm{NO}_{x}, \mathrm{O}_{x}$ channels and the $\mathrm{NO}_{2}$ channel provides measurement of $\mathrm{NO}$ and $\mathrm{O}_{3}$, respectively. The zero for the $405 \mathrm{~nm}$ channel consists of addition of clean air to the inlet. All channels operate at a repetition rate of $4 \mathrm{~Hz}$. During SENEX, the $1 \mathrm{~Hz}$ measurement precision $(2 \sigma)$ was 3 pptv for $\mathrm{NO}_{3}$ and $\mathrm{N}_{2} \mathrm{O}_{5}$, measurement precision for $\mathrm{NO}_{2}$ and $\mathrm{O}_{3}$ was $<50$ pptv, but the uncertainty in the zero for these species was 200 pptv due to an uncertainty in the relative humidity of the scrubbed air used for zeroing the instrument. The precision of the NO measurement was significantly degraded during SENEX due to a mechanical instability in the optical alignment of this cavity. This compound was not reported for the majority of flights, but had a precision of $1 \mathrm{ppbv}$ for the small number of flights with large power-plant plume intercepts containing measurable NO.

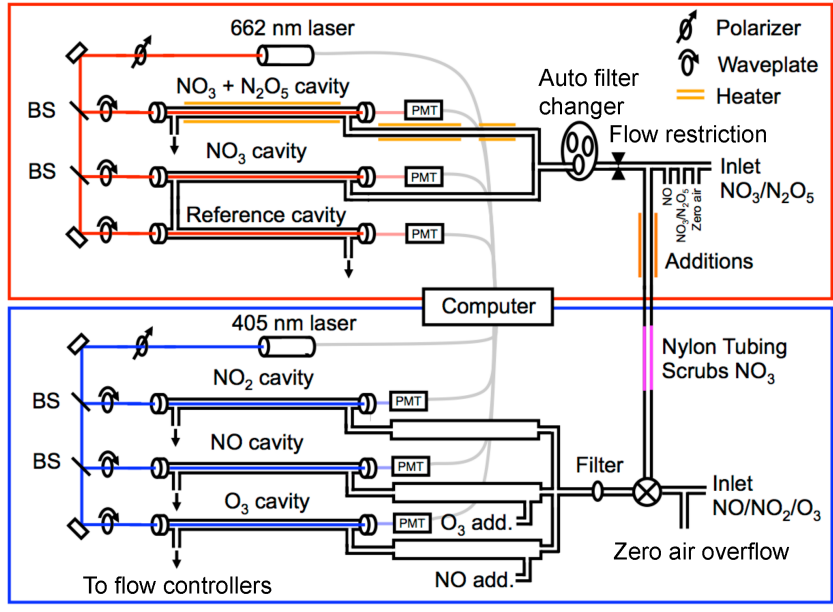

Figure A6. Schematics of the nitrogen oxide CRDS instrument.

\section{A17 In situ airborne formaldehyde (ISAF): PI Frank Keutsch, Thomas Hanisco, Glenn Wolfe}

The NASA GSFC In Situ Airborne Formaldehyde (ISAF) instrument uses laser induced fluorescence (LIF) to provide fast, sensitive observations of formaldehyde ( $\mathrm{HCHO})$ throughout the troposphere and lower stratosphere (Cazorla et al., 2015). A particle-rejecting inlet draws sample air into the low-pressure detection region at $\sim 3$ standard $\mathrm{L} \min ^{-1}$. A pulsed tunable fiber laser (NovaWave TFL) excites a single rotational transition of the $A-X$ band at $353.16 \mathrm{~nm}$, and the resulting fluorescence is detected with a photon counting photo multiplier tube. Dithering the laser on and off resonance with the rotational feature provides a continuous measure of spectroscopic background and greatly reduces the potential for measurement artifacts. The difference between power-normalized on- and off-resonance signals is proportional to the mixing ratio of $\mathrm{HCHO}$. Laser wavelength is monitored via a separate reference cell containing a high concentration of $\mathrm{HCHO}$.

The sensitivity of the LIF technique is dependent on laser power and the pressure in the detection cell. At $10 \mathrm{~mW}$ and 100 mbar, the detection limit is $\sim 36 \mathrm{pptv}$ for $1 \mathrm{~s}$ integration and $S / N=2$. The nominal sampling frequency is $10 \mathrm{~Hz}$, and mixing ratios are typically reported at $1 \mathrm{~Hz}$. The instrument was calibrated pre- and post-mission with standard addition of formaldehyde gas mixtures. The $1 \sigma$ accuracy of the measurement is $\pm 10 \%$. 
Acknowledgements. The US Weather Research Program within NOAA/OAR Office of Weather and Air Quality supported S. McKeen and R. Ahmadov. We are grateful M. Dumas (NOAA Holling's Scholar), D. Hughes, and A. Jaksich from Hendrix College for their help with the iWAS2 measurements. Participation of ISAF was enabled by US EPA Science to Achieve Results (STAR) program grant 83540601 . A. Bougiatioti, J. J. Lin, A. Nenes, and J. Kaiser. acknowledge support from NOAA OGP and EPA STAR. JK acknowledges support from NASA ESSF grant NNX14AK97H.

Edited by: G. Phillips

\section{References}

Allan, J. D., Jimenez, J. L., Williams, P. I., Alfarra, M. R., Bower, K. N., Jayne, J. T., Coe, H., and Worsnop, D. R.: Quantitative sampling using an Aerodyne aerosol mass spectrometer 1. Techniques of data interpretation and error analysis, J. Geophys. Res., 108, 4090, 909-922, 2003.

Allan, J. D., Delia, A. E., Coe, H., Bower, K. N., Alfarra, M. R., Jimenez, J. L., Middlebrook, A. M., Drewnick, F., Onasch, T. B., Canagaratna, M. R., Jayne, J. T., and Worsnop, D. R.: A generalised method for the extraction of chemically resolved mass spectra from Aerodyne aerosol mass spectrometer data, J. Aerosol Sci., 35, 909-922, 2004.

Andreae, M. O. and Merlet, P.: Emission of trace gases and aerosols from biomass burning, Global Biogeochem. Cy., 15, 955-966, 2001.

Angevine, W. M., Brioude, J., McKeen, S., and Holloway, J. S.: Uncertainty in Lagrangian pollutant transport simulations due to meteorological uncertainty from a mesoscale WRF ensemble, Geosci. Model Dev., 7, 2817-2829, doi:10.5194/gmd-7-28172014, 2014.

Bahreini, R., Dunlea, E. J., Matthew, B. M., Simons, C., Docherty, K. S., DeCarlo, P. F., Jimenez, J. L., Brock, C. A., and Middlebrook, A. M.: Design and operation of a pressure-controlled inlet for airborne sampling with an aerodynamic aerosol lens, Aerosol Sci. Technol., 42, 465-471, 2008.

Bahreini, R., Ervens, B., Middlebrook, A. M., Warneke, C., de Gouw, J. A., DeCarlo, P. F., Jimenez, J. L., Brock, C. A., Neuman, J. A., Ryerson, T. B., Stark, H., Atlas, E., Brioude, J., Fried, A., Holloway, J. S., Peischl, J., Richter, D., Walega, J., Weibring, P., Wollny, A. G., and Fehsenfeld, F. C.: Organic aerosol formation in urban and industrial plumes near Houston and Dallas, Texas, J. Geophys. Res.-Atmos., 114, D00F16, doi:10.1029/2008jd011493, 2009.

Blanchard, C. L., Hidy, G. M., Tanenbaum, S., Edgerton, E. S., and Hartsell, B. E.: The Southeastern Aerosol Research and Characterization (SEARCH) study: Temporal trends in gas and PM concentrations and composition, 1999-2010, J. Air Waste Manage., 63, 247-259, 2013.

Brioude, J., Cooper, O. R., Feingold, G., Trainer, M., Freitas, S. R., Kowal, D., Ayers, J. K., Prins, E., Minnis, P., McKeen, S. A., Frost, G. J., and Hsie, E.-Y.: Effect of biomass burning on marine stratocumulus clouds off the California coast, Atmos. Chem. Phys., 9, 8841-8856, doi:10.5194/acp-9-8841-2009, 2009.
Brioude, J., Arnold, D., Stohl, A., Cassiani, M., Morton, D., Seibert, P., Angevine, W., Evan, S., Dingwell, A., Fast, J. D., Easter, R. C., Pisso, I., Burkhart, J., and Wotawa, G.: The Lagrangian particle dispersion model FLEXPART-WRF version 3.1, Geosci. Model Dev., 6, 1889-1904, doi:10.5194/gmd-61889-2013, 2013.

Brock, C. A., Schroder, F., Bernd, K., Petzold, A., Busen, R., and Fiebig, M.: Ultrafine particle size distributions measured in aircraft exhaust plumes, J. Geophys. Res., 105, 26555-26567, 2000.

Brock, C. A., Cozic, J., Bahreini, R., Froyd, K. D., Middlebrook, A. M., McComiskey, A., Brioude, J., Cooper, O. R., Stohl, A., Aikin, K. C., de Gouw, J. A., Fahey, D. W., Ferrare, R. A., Gao, R.-S., Gore, W., Holloway, J. S., Hübler, G., Jefferson, A., Lack, D. A., Lance, S., Moore, R. H., Murphy, D. M., Nenes, A., Novelli, P. C., Nowak, J. B., Ogren, J. A., Peischl, J., Pierce, R. B., Pilewskie, P., Quinn, P. K., Ryerson, T. B., Schmidt, K. S., Schwarz, J. P., Sodemann, H., Spackman, J. R., Stark, H., Thomson, D. S., Thornberry, T., Veres, P., Watts, L. A., Warneke, C., and Wollny, A. G.: Characteristics, sources, and transport of aerosols measured in spring 2008 during the aerosol, radiation, and cloud processes affecting Arctic Climate (ARCPAC) Project, Atmos. Chem. Phys., 11, 2423-2453, doi:10.5194/acp-11-24232011, 2011.

Canagaratna, M. R., Jayne, J. T., Jimenez, J. L., Allan, J. D., Alfarra, M. R., Zhang, Q., Onasch, T. B., Drewnick, F., Coe, H., Middlebrook, A., Delia, A., Williams, L. R., Trimborn, A. M., Northway, M. J., DeCarlo, P. F., Kolb, C. E., Davidovits, P., and Worsnop, D. R.: Chemical and microphysical characterization of ambient aerosols with the Aerodyne aerosol mass spectrometer, Mass Spectrom. Rev., 26, 185-222, 2007.

Cazorla, M., Wolfe, G. M., Bailey, S. A., Swanson, A. K., Arkinson, H. L., and Hanisco, T. F.: A new airborne laser-induced fluorescence instrument for in situ detection of formaldehyde throughout the troposphere and lower stratosphere, Atmos. Meas. Tech., 8, 541-552, doi:10.5194/amt-8-541-2015, 2015.

Chang, W. L., Bhave, P. V., Brown, S. S., Riemer, N., Stutz, J., and Dabdub, D.: Heterogeneous Atmospheric Chemistry, Ambient Measurements, and Model Calculations of $\mathrm{N}_{2} \mathrm{O}_{5}$ : A Review, Aerosol Sci. Tech., 45, 665-695, 2011.

Cross, E. S., Slowik, J. G., Davidovits, P., Allan, J. D., Worsnop, D. R., Jayne, J. T., Lewis, D. K., Canagaratna, M., and Onasch, T. B.: Laboratory and ambient particle density determinations using light scattering in conjunction with aerosol mass spectrometry, Aerosol Sci. Technol., 41, 343-359, 2007.

Cross, E. S., Onasch, T. B., Canagaratna, M., Jayne, J. T., Kimmel, J., Yu, X.-Y., Alexander, M. L., Worsnop, D. R., and Davidovits, P.: Single particle characterization using a light scattering module coupled to a time-of-flight aerosol mass spectrometer, Atmos. Chem. Phys., 9, 7769-7793, doi:10.5194/acp-9-7769-2009, 2009.

Dallmann, T. R. and Harley, R. A.: Evaluation of mobile source emission trends in the United States, J. Geophys. Res.-Atmos., 115, D14305 doi:10.1029/2010jd013862, 2010.

DeCarlo, P. F., Kimmel, J. R., Trimborn, A., Northway, M. J., Jayne, J. T., Aiken, A. C., Gonin, M., Fuhrer, K., Horvath, T., Docherty, K. S., Bates, D. R., and Jimenez, J. L.: Field-Deployable, HighResolution, Time-of-Flight Aerosol Mass Spectrometer, Anal. Chem., 78, 8281-8289, doi:8210.1021/ac061249n, 2006. 
de Gouw, J. A. and Warneke, C.: Measurements of volatile organic compounds in the earths atmosphere using proton-transferreaction mass spectrometry, Mass Spectrom. Rev., 26, 223-257, 2007.

de Gouw, J., Warneke, C., Karl, T., Eerdekens, G., van der Veen, C., and Fall, R.: Sensitivity and specificity of atmospheric trace gas detection by proton-transfer-reaction mass spectrometry, Int. J. Mass Spectrom., 223, 365-382, 2003.

de Gouw, J. A., Parrish, D. D., Frost, G. J., and Trainer, M.: Reduced emissions of $\mathrm{CO}_{2}, \mathrm{NO}_{x}$, and $\mathrm{SO}_{2}$ from US power plants owing to switch from coal to natural gas with combined cycle technology, Earths Future, 2, 75-82, 2014.

de Gouw, J. A., McKeen, S. A., Aikin, K. C., Brock, C. A., Brown, S. S., Gilman, J. B., Graus, M., Hanisco, T., Holloway, J. S., Kaiser, J., Keutsch, F. N., Lerner, B. M., Liao, J., Markovic, M. Z., Middlebrook, A. M., Min, K. E., Neuman, J. A., Nowak, J. B., Peischl, J., Pollack, I. B., Roberts, J. M., Ryerson, T. B., Trainer, M., Veres, P. R., Warneke, C., Welti, A., and Wolfe, G. M.: Airborne measurements of the atmospheric emissions from a fuel ethanol refinery, J. Geophys. Res.-Atmos., 120, 4385-4397, $2015 \mathrm{a}$.

de Gouw, J. A., Trainer, M., Brown, S. S., Edwards, P., Gilman, J. B., Graus, M., Hanisco, T., Kaiser, J., Keutsch, F. N., Kim, S. W., Lerner, B. M., Neuman, J. A., Parrish, D. D., Pollack, I. B., Roberts, J. M., Ryerson, T. R., Veres, P. R., Warneke, C., and Wolfe, G. M.: Enhanced Removal of Biogenic Hydrocarbons in Power Plant Plumes Constrains the Dependence of Atmospheric Hydroxyl Concentrations on Nitrogen Oxides, Geophys. Res. Lett., in preparation, 2015 b.

DiGangi, J. P., Boyle, E. S., Karl, T., Harley, P., Turnipseed, A., Kim, S., Cantrell, C., Maudlin III, R. L., Zheng, W., Flocke, F., Hall, S. R., Ullmann, K., Nakashima, Y., Paul, J. B., Wolfe, G. M., Desai, A. R., Kajii, Y., Guenther, A., and Keutsch, F. N.: First direct measurements of formaldehyde flux via eddy covariance: implications for missing in-canopy formaldehyde sources, Atmos. Chem. Phys., 11, 10565-10578, doi:10.5194/acp-1110565-2011, 2011.

Drewnick, F., Hings, S. S., DeCarlo, P., Jayne, J. T., Gonin, M., Fuhrer, K., Weimer, S., Jimenez, J. L., Demerjian, K. L., Borrmann, S., and Worsnop, D. R.: A new time-of-flight aerosol mass spectrometer (TOF-AMS) - Instrument description and first field deployment, Aerosol Sci. Technol., 39, 637-658, 2005.

Dubé, W. P., Brown, S. S., Osthoff, H. D., Nunley, M. R., Ciciora, S. J., Paris, M. W., McLaughlin, R. J., and Ravishankara, A. R.: Aircraft instrument for simultaneous, in-situ measurements of $\mathrm{NO}_{3}$ and $\mathrm{N}_{2} \mathrm{O}_{5}$ via cavity ring-down spectroscopy, Rev. Sci. Instr., 77, 034101, doi:10.1063/1.2176058, 2006.

Emmons, L. K., Arnold, S. R., Monks, S. A., Huijnen, V., Tilmes, S., Law, K. S., Thomas, J. L., Raut, J.-C., Bouarar, I., Turquety, S., Long, Y., Duncan, B., Steenrod, S., Strode, S., Flemming, J., Mao, J., Langner, J., Thompson, A. M., Tarasick, D., Apel, E. C., Blake, D. R., Cohen, R. C., Dibb, J., Diskin, G. S., Fried, A., Hall, S. R., Huey, L. G., Weinheimer, A. J., Wisthaler, A., Mikoviny, T., Nowak, J., Peischl, J., Roberts, J. M., Ryerson, T., Warneke, C., and Helmig, D.: The POLARCAT Model Intercomparison Project (POLMIP): overview and evaluation with observations, Atmos. Chem. Phys., 15, 6721-6744, doi:10.5194/acp15-6721-2015, 2015.
Fiedler, S. E., Hese, A., and Ruth, A. A.: Incoherent broad-band cavity-enhanced absorption spectroscopy, Chem. Phys. Lett., 371, 284-294, 2003.

Fu, T.-M., Jacob, D. J., Wittrock, F., Burrows, J. P., Vrekoussis, M., and Henze, D. K.: Global budgets of atmospheric glyoxal and methylglyoxal, and implications for formation of secondary organic aerosols, J. Geophys. Res.-Atmos., 113, D15303, doi:10.1029/2007jd009505, 2008.

Fuchs, H., Dubé, W. P., Lerner, B. M., Wagner, N. L., Williams, E. J., and Brown, S. S.: A sensitive and versatile detector for atmospheric $\mathrm{NO}_{2}$ and $\mathrm{NO}_{x}$ basd on blue diode laser cavity ring-down spectroscopy, Environ. Sci. Technol., 43, 7831-7836, 2009.

Gilman, J. B., Kuster, W. C., Goldan, P. D., Herndon, S. C., Zahniser, M. S., Tucker, S. C., Brewer, W. A., Lerner, B. M., Williams, E. J., Harley, R. A., Fehsenfeld, F. C., Warneke, C., and de Gouw, J. A.: Measurements of volatile organic compounds during the 2006 TexAQS/GoMACCS campaign: Industrial influences, regional characteristics, and diurnal dependencies of the OH reactivity, J. Geophys. Res.-Atmos., 114, D00f06, doi:10.1029/2008jd011525, 2009.

Holloway, J. S., Jakoubek, R. O., Parrish, D. D., Gerbig, C., VolzThomas, A., Schmitgen, S., Fried, A., Wert, B., Henry, B., and Drummond, J. R.: Airborne intercomparison of vacuum ultraviolet fluorescence and tunable diode laser absorption measurements of tropospheric carbon monoxide, J. Geophys. Res., 105, 24251-224261, 2000.

Hottle, J. R., Huisman, A. J., Digangi, J. P., Kammrath, A., Galloway, M. M., Coens, K. L., and Keutsch, F. N.: A Laser Induced Fluorescence-Based Instrument for In-Situ Measurements of Atmospheric Formaldehyde, Environ. Sci. Technol., 43, 790-795, 2009.

Jayne, J. T., Leard, D. C., Zhang, X., Davidovits, P., Smith, K. A., Kolb, C. E., and Worsnop, D. R.: Development of an aerosol mass spectrometer for size and composition analysis of submicron particles, Aerosol Sci. Technol., 33, 49-70, 2000.

Jimenez, J. L., Jayne, J. T., Shi, Q., Kolb, C. E., Worsnop, D. R., Yourshaw, I., Seinfeld, J. H., Flagan, R. C., Zhang, X., Smith, K. A., Morris, J. W., and Davidovits, P.: Ambient aerosol sampling using the Aerodyne aerosol mass spectrometer, J. Geophys. Res., 108, 8425, doi:10.1029/2001JD001213, 2003.

Kaiser, J., Wolfe, G. M., Min, K. E., Brown, S. S., Miller, C. C., Jacob, D. J., deGouw, J. A., Graus, M., Hanisco, T. F., Holloway, J., Peischl, J., Pollack, I. B., Ryerson, T. B., Warneke, C., Washenfelder, R. A., and Keutsch, F. N.: Reassessing the ratio of glyoxal to formaldehyde as an indicator of hydrocarbon precursor speciation, Atmos. Chem. Phys., 15, 7571-7583, doi:10.5194/acp-157571-2015, 2015.

Kercher, J. P., Riedel, T. P., and Thornton, J. A.: Chlorine activation by $\mathrm{N}_{2} \mathrm{O}_{5}$ : simultaneous, in situ detection of $\mathrm{ClNO}_{2}$ and $\mathrm{N}_{2} \mathrm{O}_{5}$ by chemical ionization mass spectrometry, Atmos. Meas. Tech., 2, 193-204, doi:10.5194/amt-2-193-2009, 2009.

Kiendler-Scharr, A., Zhang, Q., Hohaus, T., Kleist, E., Mensah, A., Mentel, T. F., Spindler, C., Uerlings, R., Tillmann, R., and Wildt, J.: Aerosol mass spectrometric features of biogenic SOA: Observations from a plant chamber and in rural atmospheric environments, Environ. Sci. Technol., 43, 8166-8172, 2009.

Kondo, Y., Matsui, H., Moteki, N., Sahu, L., Takegawa, N., Kajino, M., Zhao, Y., Cubison, M. J., Jimenez, J. L., Vay, S., Diskin, G. S., Anderson, B., Wisthaler, A., Mikoviny, T., Fuel- 
berg, H. E., Blake, D. R., Huey, G., Weinheimer, A. J., Knapp, D. J., and Brune, W. H.: Emissions of black carbon, organic, and inorganic aerosols from biomass burning in North America and Asia in 2008, J. Geophys. Res.-Atmos., 116, D08204, doi:10.1029/2010jd015152, 2011.

Lack, D. A., Richardson, M. S., Law, D., Langridge, J. M., Cappa, C. D., McLaughlin, R. J., and Murphy, D. M.: Aircraft Instrument for Comprehensive Characterization of Aerosol Optical Properties, Part 2: Black and Brown Carbon Absorption and Absorption Enhancement Measured with Photo Acoustic Spectroscopy, Aerosol Sci. Tech., 46, 555-568, 2012.

Lance, S., Medina, J., Smith, J. N., and Nenes, A.: Mapping the operation of the DMT Continuous Flow CCN counter, Aerosol Sci. Tech., 40, 242-254, 2006.

Lance, S., Brock, C. A., Rogers, D., and Gordon, J. A.: Water droplet calibration of the Cloud Droplet Probe (CDP) and inflight performance in liquid, ice and mixed-phase clouds during ARCPAC, Atmos. Meas. Tech., 3, 1683-1706, doi:10.5194/amt3-1683-2010, 2010.

Langridge, J. M., Richardson, M. S., Lack, D., Law, D., and Murphy, D. M.: Aircraft Instrument for Comprehensive Characterization of Aerosol Optical Properties, Part I: Wavelength-Dependent Optical Extinction and Its Relative Humidity Dependence Measured Using Cavity Ringdown Spectroscopy, Aerosol Sci. Tech., 45, 1305-1318, 2011.

Lee, B. H., Lopez-Hilfiker, F. D., Mohr, C., Kurten, T., Worsnop, D. R., and Thornton, J. A.: An Iodide-Adduct High-Resolution Time-of-Flight Chemical-Ionization Mass Spectrometer: Application to Atmospheric Inorganic and Organic Compounds, Environ. Sci. Technol., 48, 6309-6317, 2014.

Lerner, B. M., Gilman, J. B., Aikin, K. C., Atlas, E. L., Goldan, P. D., Graus, M., Hendershot, R., Isaacman-VanWertz, G. A., Koss, A., Kuster, W. C., Lueb, R. A., McLaughlin, R. J., Peischl, J., Sueper, D., Ryerson, T. B., Tokarek, T. W., Warneke, C., Yuan, B., and de Gouw, J. A.: An Improved, Automated Whole-Air Sampler and Gas Chromatography Mass Spectrometry Analysis System for Volatile Organic Compounds in the Atmosphere, Atmos. Meas. Tech. Discuss., doi:10.5194/amt-2016-210, in review, 2016.

Li, Q., Mao, J., Min, K. E., Washenfelder, R. A., brown, S. S., Kaiser, J., Keutsch, F. N., Volkamer, R., Wolfe, G. M., Hanisco, T. F., Pollack, I., Ryerson, T. B., Graus, M. G., Gilman, J. B., Lerner, B., Warneke, C., de Gouw, J. A., Middlebrook, A. M., Liao, J., Welti, A., Henderson, B. H., McNeill, V. F., Hall, S. R., Ullmann, K., Donner, L. J., Paulot, F., and Horowitz, L. W.: Observational constraints on glyoxal production from isoprene oxidation and its contribution to organic aerosol over the Southeast United States, Geophys. Res. Lett., submitted, 2016.

Lin, J. J., Purdue, S., Raatikainen, T., and Nenes, A.: Unraveling the Development of Supersaturation under Dynamic Flow Operation of CCN Counters, in preparation, 2016.

Liu, P., Ziemann, P. J., Kittelson, D. B., and McMurry, P. H.: Generating Particle Beams of Controlled Dimensions and Divergence: I. Theory of Particle Motion in Aerodynamic Lenses and Nozzle Expansion, Aerosol Sci. Technol., 22, 293-313, 1995.

Liu, S., Russell, L. M., Sueper, D. T., and Onasch, T. B.: Organic particle types by single-particle measurements using a time-offlight aerosol mass spectrometer coupled with a light scattering module, Atmos. Meas. Tech., 6, 187-197, doi:10.5194/amt-6187-2013, 2013.

Matthew, B. M., Middlebrook, A. M., and Onasch, T. B.: Collection efficiencies in an Aerodyne aerosol mass spectrometer as a function of particle phase for laboratory generated aerosols, Aerosol Sci. Technol., 42, 884-898, 2008.

Middlebrook, A. M., Bahreini, R., Jimenez, J. L., and Canagaratna, M. R.: Evaluation of composition-dependent collection efficiencies for the Aerodyne aerosol mass spectrometer using field data, Aerosol Sci. Technol., 46, 258-271, 2012.

Mielke, L. H., Furgeson, A., and Osthoff, H. D.: Observation of $\mathrm{CINO}_{2}$ in a Mid-Continental Urban Environment, Environ. Sci. Technol., 45, 8889-8896, 2011.

Min, K.-E., Washenfelder, R. A., Dubé, W. P., Langford, A. O., Edwards, P. M., Zarzana, K. J., Stutz, J., Lu, K., Rohrer, F., Zhang, Y., and Brown, S. S.: A broadband cavity enhanced absorption spectrometer for aircraft measurements of glyoxal, methylglyoxal, nitrous acid, nitrogen dioxide, and water vapor, Atmos. Meas. Tech., 9, 423-440, doi:10.5194/amt-9-423-2016, 2016.

Moore, R. H. and Nenes, A.: Scanning Flow CCN Analysis-A Method for Fast Measurements of CCN Spectra, Aerosol Sci. Tech., 43, 1192-1207, 2009.

Moore, R. H., Cerully, K., Bahreini, R., Brock, C. A., Middlebrook, A. M., and Nenes, A.: Hygroscopicity and composition of California CCN during summer 2010, J. Geophys. Res.-Atmos., 117, D00V12, doi:10.1029/2011jd017352, 2012.

Neuman, J. A., Trainer, M., Brown, S. S., Min, K.-E., Nowak, J. B., Parrish, D. D., Peischl, J., Pollack, I., Roberts, J. M., Ryerson, T. B., and Veres, P. R.: HONO sources to the troposphere in the Southeast U.S., J. Geophys. Res., doi:2016JD025197, in review, 2016.

Neuman, J. A., Huey, L. G., Dissly, R. W., Fehsenfeld, F. C., Flocke, F., Holecek, J. C., Holloway, J. S., Hubler, G., Jakoubek, R., Nicks Jr., D. K., Parrish, D. D., Ryerson, T. B., Sueper, D. T., and Weinheimer, A. J.: Fast-response airborne in situ measurements of HNO3 during the Texas 2000 Air Quality Study, J. Geophys. Res., 107, 4436, doi:4410.1029/2001JD001437, 2002.

Neuman, J. A., Ryerson, T. B., Huey, L. G., Jakoubek, R., Nowak, J. B., Simons, C., and Fehsenfeld, F. C.: Calibration and evaluation of nitric acid and ammonia permeation tubes by UV optical absorption, Environ. Sci. Technol., 37, 2975-2981, 2003.

Neuman, J. A., Nowak, J. B., Huey, L. G., Burkholder, J. B., Dibb, J. E., Holloway, J. S., Liao, J., Peischl, J., Roberts, J. M., Ryerson, T. B., Scheuer, E., Stark, H., Stickel, R. E., Tanner, D. J., and Weinheimer, A.: Bromine measurements in ozone depleted air over the Arctic Ocean, Atmos. Chem. Phys., 10, 6503-6514, doi:10.5194/acp-10-6503-2010, 2010.

Nowak, J. B., Neuman, J. A., Kozai, K., Huey, L. G., Tanner, D. J., Holloway, J. S., Ryerson, T. B., Frost, G. J., McKeen, S. A., and Fehsenfeld, F. C.: A chemical ionization mass spectrometry technique for airborne measurements of ammonia, J. Geophys. Res.-Atmos., 112, D10s02, doi:10.1029/2006jd007589, 2007.

Nowak, J. B., Neuman, J. A., Bahreini, R., Brock, C. A., Middlebrook, A. M., Wollny, A. G., Holloway, J. S., Peischl, J., Ryerson, T. B., and Fehsenfeld, F. C.: Airborne observations of ammonia and ammonium nitrate formation over Houston, Texas, J. Geophys. Res.-Atmos., 115, D22304, doi:10.1029/2010jd014195, 2010. 
Nowak, J. B., Neuman, J. A., Bahreini, R., Middlebrook, A. M., Holloway, J. S., McKeen, S. A., Parrish, D. D., Ryerson, T. B., and Trainer, M.: Ammonia sources in the California South Coast Air Basin and their impact on ammonium nitrate formation, Geophys. Res. Lett., 39, L07804, doi:10.1029/2012g1051197, 2012.

Osthoff, H. D., Roberts, J. M., Ravishankara, A. R., Williams, E. J., Lerner, B. M., Sommariva, R., Bates, T. S., Coffman, D., Quinn, P. K., Dibb, J. E., Stark, H., Burkholder, J. B., Talukdar, R. K., Meagher, J., Fehsenfeld, F. C., and Brown, S. S.: High levels of nitryl chloride in the polluted subtropical marine boundary layer, Nat. Geosci., 1, 324-328, 2008.

Park, K., Kittelson, D. B., Zachariah, M. R., and McMurry, P. H.: Measurement of inherent material density of nanoparticle agglomerates, J. Nanoparticle Res., 6, 267-272, 2004.

Peischl, J., Ryerson, T. B., Holloway, J. S., Trainer, M., Andrews, A. E., Atlas, E. L., Blake, D. R., Daube, B. C., Dlugokencky, E. J., Fischer, M. L., Goldstein, A. H., Guha, A., Karl, T., Kofler, J., Kosciuch, E., Misztal, P. K., Perring, A. E., Pollack, I. B., Santoni, G. W., Schwarz, J. P., Spackman, J. R., Wofsy, S. C., and Parrish, D. D.: Airborne observations of methane emissions from rice cultivation in the Sacramento Valley of California, J. Geophys. Res.-Atmos., 117, D00v25, doi:10.1029/2012jd017994, 2012.

Peischl, J., Ryerson, T. B., Aikin, K. C., de Gouw, J. A., Gilman, J. B., Holloway, J. S., Lerner, B. M., Nadkarni, R., Neuman, J. A., Nowak, J. B., Trainer, M., Warneke, C., and Parrish, D. D.: Quantifying atmospheric methane emissions from the Haynesville, Fayetteville, and northeastern Marcellus shale gas production regions, J. Geophys. Res.-Atmos., 120, 2119-2139, 2015.

Perry, R. H. and Green, D. W. (Eds.): Perry's Chemical Engineers' Handbook, McGraw-Hill, New York, NY, ISBN-13: 9780071422949, 1997.

Phillips, G. J., Pouvesle, N., Thieser, J., Schuster, G., Axinte, R., Fischer, H., Williams, J., Lelieveld, J., and Crowley, J. N.: Peroxyacetyl nitrate (PAN) and peroxyacetic acid (PAA) measurements by iodide chemical ionisation mass spectrometry: first analysis of results in the boreal forest and implications for the measurement of PAN fluxes, Atmos. Chem. Phys., 13, 11291139, doi:10.5194/acp-13-1129-2013, 2013.

Pollack, I. B., Lerner, B. M., and Ryerson, T. B.: Evaluation of ultraviolet light-emitting diodes for detection of atmospheric $\mathrm{NO}_{2}$ by photolysis - chemiluminescence, J. Atmos. Chem., 65, 111-125, 2010.

Raatikainen, T., Moore, R. H., Lathem, T. L., and Nenes, A.: A coupled observation - modeling approach for studying activation kinetics from measurements of CCN activity, Atmos. Chem. Phys., 12, 4227-4243, doi:10.5194/acp-12-4227-2012, 2012.

Raatikainen, T., Nenes, A., Seinfeld, J. H., Morales, R., Moore, R. H., Lathem, T. L., Lance, S., Padro, L. T., Lin, J. J., Cerully, K. M., Bougiatioti, A., Cozic, J., Ruehl, C. R., Chuang, P. Y., Anderson, B. E., Flagan, R. C., Jonsson, H., Mihalopoulos, N., and Smith, J. N.: Worldwide data sets constrain the water vapor uptake coefficient in cloud formation, P. Natl. Acad. Sci. USA, 110, 3760-3764, 2013.

Raatikainen, T., Lin, J. J., Cerully, K. M., Lathem, T. L., Moore, R. H., and Nenes, A.: CCN Data Interpretation Under Dynamic Operation Conditions, Aerosol Sci. Tech., 48, 552-561, 2014.
Roberts, G. C. and Nenes, A.: A continuous-flow streamwise thermal-gradient $\mathrm{CCN}$ chamber for atmospheric measurements, Aerosol Sci. Tech., 39, 206-221, 2005.

Roberts, J. M., Veres, P., Warneke, C., Neuman, J. A., Washenfelder, R. A., Brown, S. S., Baasandorj, M., Burkholder, J. B., Burling, I. R., Johnson, T. J., Yokelson, R. J., and de Gouw, J.: Measurement of HONO, HNCO, and other inorganic acids by negative-ion proton-transfer chemical-ionization mass spectrometry (NI-PT-CIMS): application to biomass burning emissions, Atmos. Meas. Tech., 3, 981-990, doi:10.5194/amt-3-981-2010, 2010.

Roiger, A., Aufmhoff, H., Stock, P., Arnold, F., and Schlager, H.: An aircraft-borne chemical ionization - ion trap mass spectrometer (CI-ITMS) for fast PAN and PPN measurements, Atmos. Meas. Tech., 4, 173-188, doi:10.5194/amt-4-173-2011, 2011.

Ryerson, T. B., Buhr, M. P., Frost, G. J., Goldan, P. D., Holloway, J. S., Hübler, G., Jobson, B. T., Kuster, W. C., McKeen, S. A., Parrish, D. D., Roberts, J. M., Sueper, D. T., Trainer, M., Williams, J., and Fehsenfeld, F. C.: Emissions lifetimes and ozone formation in power plant plumes, J. Geophys. Res., 103, 22569-22583, 1998.

Ryerson, T. B., Huey, L. G., Knapp, K., Neuman, J. A., Parrish, D. D., Sueper, D. T., and Fehsenfeld, F. C.: Design and initial characterization of an inlet for gas-phase $\mathrm{NO}_{y}$ measurements from aircraft, J. Geophys. Res., 104, 5483-5492, 1999.

Ryerson, T. B., Williams, E. J., and Fehsenfeld, F. C.: An efficient photolysis system for fast-response $\mathrm{NO}_{2}$ measurements, J. Geophys. Res., 105, 26447-26461, 2000.

Schauffler, S. M., Atlas, E. L., Donnelly, S. G., Andrews, A., Montzka, S. A., Elkins, J. W., Hurst, D. F., Romashkin, P. A., Dutton, G. S., and Stroud, V.: Chlorine budget and partitioning during the Stratospheric Aerosol and Gas Experiment (SAGE) III Ozone Loss and Validation Experiment (SOLVE), J. Geophys. Res.-Atmos., 108, 993-1001, 2003.

Schwarz, J. P., Gao, R. S., Fahey, D. W., Thomson, D. S., Watts, L. A., Wilson, J. C., Reeves, J. M., Darbeheshti, M., Baumgardner, D. G., Kok, G. L., Chung, S. H., Schulz, M., Hendricks, J., Lauer, A., Kaercher, B., Slowik, J. G., Rosenlof, K. H., Thompson, T. L., Langford, A. O., Loewenstein, M., and Aikin, K. C.: Single-particle measurements of midlatitude black carbon and light-scattering aerosols from the boundary layer to the lower stratosphere, J. Geophys. Res.-Atmos., 111, D16207, doi:10.1029/2006jd007076, 2006.

Schwarz, J. P., Spackman, J. R., Fahey, D. W., Gao, R. S., Lohmann, U., Stier, P., Watts, L. A., Thomson, D. S., Lack, D. A., Pfister, L., Mahoney, M. J., Baumgardner, D., Wilson, J. C., and Reeves, J. M.: Coatings and their enhancement of black carbon light absorption in the tropical atmosphere, J. Geophys. Res.-Atmos., 113, D03203, doi:10.1029/2007jd009042, 2008.

Schwarz, J. P., Spackman, J. R., Gao, R. S., Watts, L. A., Stier, P., Schulz, M., Davis, S. M., Wofsy, S. C., and Fahey, D. W.: Global-scale black carbon profiles observed in the remote atmosphere and compared to models, Geophys. Res. Lett., 37, L18812, doi:10.1029/2010g1046007, 2010.

Slowik, J. G., Stroud, C., Bottenheim, J. W., Brickell, P. C., Chang, R. Y.-W., Liggio, J., Makar, P. A., Martin, R. V., Moran, M. D., Shantz, N. C., Sjostedt, S. J., van Donkelaar, A., Vlasenko, A., Wiebe, H. A., Xia, A. G., Zhang, J., Leaitch, W. R., and Abbatt, J. P. D.: Characterization of a large biogenic secondary or- 
ganic aerosol event from eastern Canadian forests, Atmos. Chem. Phys., 10, 2825-2845, doi:10.5194/acp-10-2825-2010, 2010.

Slusher, D. L., Huey, L. G., Tanner, D. J., Flocke, F. M., and Roberts, J. M.: A thermal dissociation-chemical ionization mass spectrometry (TD-CIMS) technique for the simultaneous measurement of peroxyacyl nitrates and dinitrogen pentoxide, J. Geophys. Res.-Atmos., 109, D19315, doi:10.1029/2004jd004670, 2004.

Stohl, A., Forster, C., Frank, A., Seibert, P., and Wotawa, G.: Technical note: The Lagrangian particle dispersion model FLEXPART version 6.2, Atmos. Chem. Phys., 5, 2461-2474, doi:10.5194/acp-5-2461-2005, 2005.

Stohl, A., Berg, T., Burkhart, J. F., Fjæraa, A. M., Forster, C., Herber, A., Hov, Ø., Lunder, C., McMillan, W. W., Oltmans, S., Shiobara, M., Simpson, D., Solberg, S., Stebel, K., Ström, J., Tørseth, K., Treffeisen, R., Virkkunen, K., and Yttri, K. E.: Arctic smoke - record high air pollution levels in the European Arctic due to agricultural fires in Eastern Europe in spring 2006, Atmos. Chem. Phys., 7, 511-534, doi:10.5194/acp-7-511-2007, 2007.

Thaler, R. D., Mielke, L. H., and Osthoff, H. D.: Quantification of Nitryl Chloride at Part Per Trillion Mixing Ratios by Thermal Dissociation Cavity Ring-Down Spectroscopy, Anal. Chem., 83, 2761-2766, 2011.

Veres, P. R. and Roberts, J. M.: Development of a photochemical source for the production and calibration of acyl peroxynitrate compounds, Atmos. Meas. Tech., 8, 2225-2231, doi:10.5194/amt-8-2225-2015, 2015.

Veres, P., Roberts, J. M., Warneke, C., Welsh-Bon, D., Zahniser, M., Herndon, S., Fall, R., and de Gouw, J.: Development of negativeion proton-transfer chemical-ionization mass spectrometry (NIPT-CIMS) for the measurement of gas-phase organic acids in the atmosphere, Int. J. Mass Spectrom., 274, 48-55, 2008.

Veres, P., Gilman, J. B., Roberts, J. M., Kuster, W. C., Warneke, C., Burling, I. R., and de Gouw, J.: Development and validation of a portable gas phase standard generation and calibration system for volatile organic compounds, Atmos. Meas. Tech., 3, 683-691, doi:10.5194/amt-3-683-2010, 2010.

von Schneidemesser, E., Monks, P. S., and Plass-Duelmer, C.: Global comparison of VOC and CO observations in urban areas, Atmos. Environ., 44, 5053-5064, 2010.

Wagner, N. L., Dubé, W. P., Washenfelder, R. A., Young, C. J., Pollack, I. B., Ryerson, T. B., and Brown, S. S.: Diode laser-based cavity ring-down instrument for $\mathrm{NO}_{3}, \mathrm{~N}_{2} \mathrm{O}_{5}, \mathrm{NO}$, $\mathrm{NO}_{2}$ and $\mathrm{O}_{3}$ from aircraft, Atmos. Meas. Tech., 4, 1227-1240, doi:10.5194/amt-4-1227-2011, 2011.

Warneke, C., Roberts, J. M., Veres, P., Gilman, J., Kuster, W. C., Burling, I., Yokelson, R., and de Gouw, J. A.: VOC identification and inter-comparison from laboratory biomass burning using PTR-MS and PIT-MS, Int. J. Mass Spectrom., 303, 6-14, $2011 \mathrm{a}$.

Warneke, C., Veres, P., Holloway, J. S., Stutz, J., Tsai, C., Alvarez, S., Rappenglueck, B., Fehsenfeld, F. C., Graus, M., Gilman, J. B., and de Gouw, J. A.: Airborne formaldehyde measurements using PTR-MS: calibration, humidity dependence, intercomparison and initial results, Atmos. Meas. Tech., 4, 23452358, doi:10.5194/amt-4-2345-2011, 2011 b.

Warneke, C., de Gouw, J. A., Holloway, J. S., Peischl, J., Ryerson, T. B., Atlas, E., Blake, D., Trainer, M., and Parrish, D. D.: Multiyear trends in volatile organic compounds in Los Angeles, California:
Five decades of decreasing emissions, J. Geophys. Res.-Atmos., 117, D00v17, doi:10.1029/2012jd017899, 2012.

Washenfelder, R. A., Langford, A. O., Fuchs, H., and Brown, S. S.: Measurement of glyoxal using an incoherent broadband cavity enhanced absorption spectrometer, Atmos. Chem. Phys., 8, 7779-7793, doi:10.5194/acp-8-7779-2008, 2008.

Washenfelder, R. A., Dubé, W. P., Wagner, N. L., and Brown, S. S.: Measurement of atmospheric ozone by cavity ring-down spectroscopy, Environ. Sci. Technol., 45, 2938-2944, 2011 a.

Washenfelder, R. A., Young, C. J., Brown, S. S., Angevine, W. M., Atlas, E. L., Blake, D. R., Bon, D. M., Cubinson, M. J., de Gouw, J. A., Dusanter, S., Flynn, J., Gilman, J. B., Graus, M., Griffith, S., Grossberg, N., Hayes, P. L., Jimenez, J. L., Kuster, W. C., Lefer, B. L., Pollack, I. B., Ryerson, T. B., Stark, H., Stevens, P. S., and Trainer, M. K.: The glyoxal budget and its contribution to organic aerosol for Los Angeles, California during CalNex 2010, J. Geophys. Res., 116, D00v02, doi:10.1029/2011jd016314, 2011 b.

Wild, R. J., Edwards, P. M., Dube, W. P., Baumann, K., Edgerton, E. S., Quinn, P. K., Roberts, J. M., Rollins, A. W., Veres, P. R., Warneke, C., Williams, E. J., Yuan, B., and Brown, S. S.: A Measurement of Total Reactive Nitrogen, NOy, together with $\mathrm{NO}_{2}$, NO, and O-3 via Cavity Ring-down Spectroscopy, Environ. Sci. Technol., 48, 9609-9615, 2014.

Wilson, J. C., Lafleur, B. G., Hilbert, H., Seebaugh, W. R., Fox, J., Gesler, D. W., Brock, C. A., Huebert, B. J., and Mullen, J.: Function and performance of a low turbulence inlet for sampling supermicron particles from aircraft platforms, Aerosol Sci. Tech., 38, 790-802, 2004.

Wolfe, G. M., Kaiser, J., Hanisco, T. F., Keutsch, F. N., de Gouw, J. A., Gilman, J. B., Graus, M., Hatch, C. D., Holloway, J., Horowitz, L. W., Lee, B. H., Lerner, B. M., Lopez-Hilifiker, F., Mao, J., Marvin, M. R., Peischl, J., Pollack, I. B., Roberts, J. M., Ryerson, T. B., Thornton, J. A., Veres, P. R., and Warneke, C.: Formaldehyde production from isoprene oxidation across NOx regimes, Atmos. Chem. Phys., 16, 2597-2610, doi:10.5194/acp16-2597-2016, 2016.

Wolfe, G. M., Kaiser, J., Hanisco, T. F., Keutsch, F. N., de Gouw, J. A., Gilman, J. B., Graus, M., Hatch, C. D., Holloway, J., Horowitz, L. W., Lee, B. H., Lerner, B. M., Lopez-Hilifiker, F., Mao, J., Marvin, M. R., Peischl, J., Pollack, I. B., Roberts, J. M., Ryerson, T. B., Thornton, J. A., Veres, P. R., and Warneke, C.: Formaldehyde production from isoprene oxidation across NOx regimes, Atmos. Chem. Phys., 16, 2597-2610, doi:10.5194/acp16-2597-2016, 2016.

Young, C. J., Washenfelder, R. A., Roberts, J. M., Mielke, L. H., Osthoff, H. D., Tsai, C., Pikelnaya, O., Stutz, J., Veres, P. R., Cochran, A. K., VandenBoer, T. C., Flynn, J., Grossberg, N., Haman, C. L., Lefer, B., Stark, H., Graus, M., de Gouw, J., Gilman, J. B., Kuster, W. C., and Brown, S. S.: Vertically Resolved Measurements of Nighttime Radical Reservoirs; in Los Angeles and Their Contribution to the Urban Radical Budget, Environ. Sci. Technol., 46, 10965-10973, 2012.

Yuan, B., Kaser, L., Karl, T., Graus, M., Peischl, J., Campos, T. L., Shertz, S., Apel, E. C., Hornbrook, R. S., Hills, A., Gilman, J. B., Lerner, B. M., Warneke, C., Flocke, F. M., Ryerson, T. B., Guenther, A. B., and de Gouw, J. A.: Airborne flux measurements of methane and volatile organic compounds over the Haynesville 
and Marcellus shale gas production regions, J. Geophys. Res.Atmos., 120, 6271-6289, 2015.

Zelenyuk, A., Imre, D., Han, J. H., and Oatis, S.: Simultaneous measurements of individual ambient particle size, composition, effective density, and hygroscopicity, Anal. Chem., 80, 1401-1407, 2008.
Zheng, W., Flocke, F. M., Tyndall, G. S., Swanson, A., Orlando, J. J., Roberts, J. M., Huey, L. G., and Tanner, D. J.: Characterization of a thermal decomposition chemical ionization mass spectrometer for the measurement of peroxy acyl nitrates (PANs) in the atmosphere, Atmos. Chem. Phys., 11, 6529-6547, doi:10.5194/acp-11-6529-2011, 2011. 